\title{
Archeological and Geoarcheological Survey of State Highway 35 between Angleton and Old Ocean, Brazoria County, Texas
}

Richard B. Mahoney

David D. Kuehn

Jason D. Weston

Follow this and additional works at: https://scholarworks.sfasu.edu/ita

Part of the American Material Culture Commons, Archaeological Anthropology Commons, Environmental Studies Commons, Other American Studies Commons, Other Arts and Humanities Commons, Other History of Art, Architecture, and Archaeology Commons, and the United States History Commons

Tell us how this article helped you.

This Article is brought to you for free and open access by the Center for Regional Heritage Research at SFA ScholarWorks. It has been accepted for inclusion in Index of Texas Archaeology: Open Access Gray Literature from the Lone Star State by an authorized editor of SFA ScholarWorks. For more information, please contact cdsscholarworks@sfasu.edu. 


\section{Archeological and Geoarcheological Survey of State Highway 35 between Angleton and Old Ocean, Brazoria County, Texas}

\section{Licensing Statement}

This is a work produced for the Texas Department of Transportation (TxDOT) by the report producer. TxDOT and the report producer jointly own all rights, title, and interest in and to all intellectual property developed under TXDOT's contract with the report producer. The report may be cited and brief passages from this publication may be reproduced without permission provided that credit is given to both TXDOT and the report producer. Permission to reprint an entire chapter, section, figures or tables must be obtained in advance from either the Supervisor of the Archeological Studies Branch, Environmental Affairs Division, Texas Department of Transportation, 125 East 11th Street, Austin, Texas, 78701 or from the report producer. 


\section{Archeological and Geoarcheological Survey of State Highway 35 between Angleton and Old Ocean, Brazoria County, Texas}

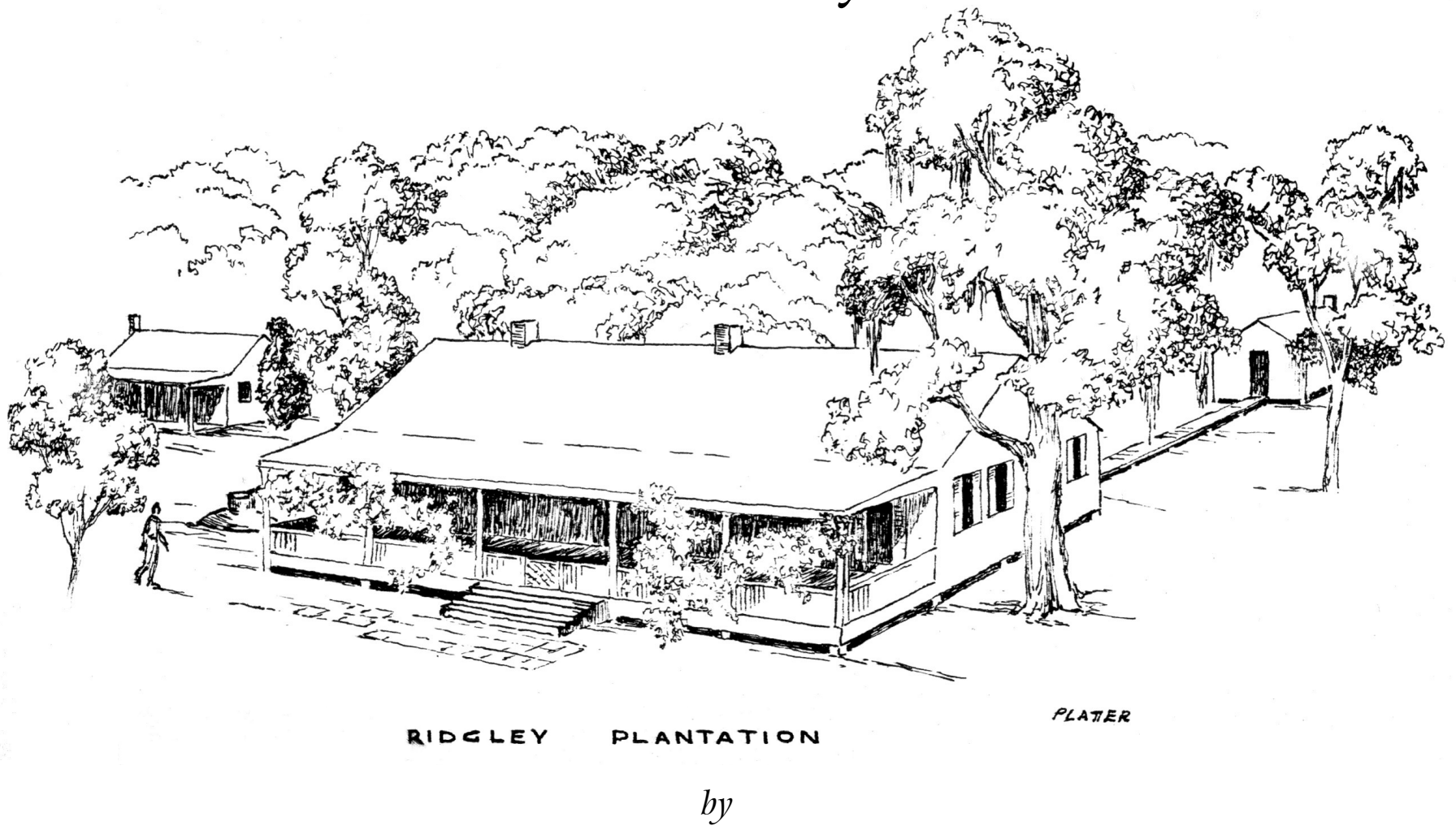

Richard B. Mahoney, David D. Kuehn, and Jason D. Weston

with a Historic Context by

Justin B. Edgington

Hardy-Heck-Moore, Inc.

Texas Antiquities Committee Permit No. 3091

Work Authorization No. 57301 SA002

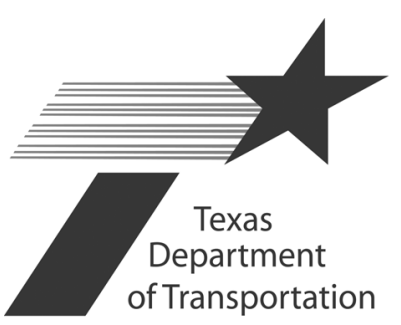

Environmental Affairs Division

Texas Department of Transportation

Archeological Studies Program
Contract No. 573 XX SA002

CSJ: 0179-01-028

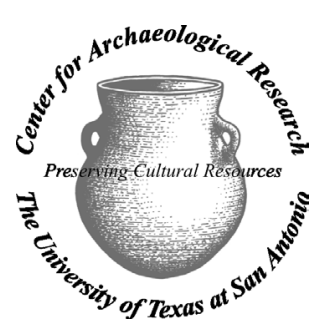

Center for Archaeological Research The University of Texas at San Antonio Archaeological Survey Report, No. 320 


\title{
Archeological and Geoarcheological Survey of State Highway 35 between Angleton and Old Ocean, Brazoria County, Texas
}

\author{
by \\ Richard B. Mahoney, David D. Kuehn, and Jason D. Weston \\ with a Historic Context by \\ Justin B. Edgington \\ Hardy-Heck-Moore, Inc.
}

Texas Antiquities Committee Permit No. 3091

Steve A. Tomka

Principal Investigator

Work Authorization No. 57301 SA002

Contract No. 573 XX SA002

CSJ: 0179-01-028

Prepared for:

Environmental Affairs Division

Texas Department of Transportation

Archeological Studies Program

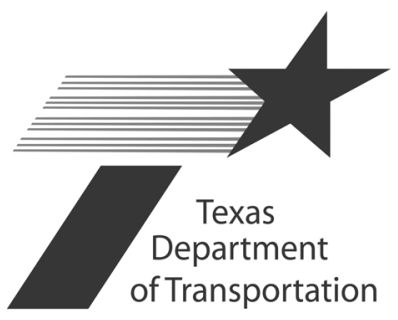

Prepared by:

Center for Archaeological Research The University of Texas at San Antonio Archaeological Survey Report, No. 320

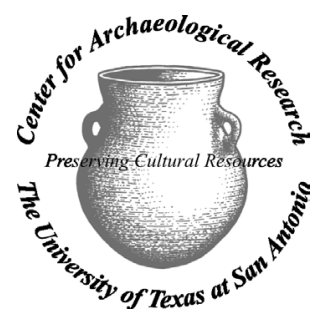




\title{
Archeological and Geoarcheological Survey of State Highway 35 between Angleton and Old Ocean, Brazoria County, Texas
}

\author{
Copyright ${ }^{(} 2003$ \\ Texas Department of Transportation (TxDOT) and Center for Archaeological Research, \\ The University of Texas at San Antonio (CAR-UTSA)
}

\begin{abstract}
All rights reserved
TxDOT and CAR-UTSA jointly own all rights, title, and interest in and to all data and other information developed for this project under Contract $573 \mathrm{XX}$ SA002. Brief passages from this publication may be reproduced without permission provided that credit is given to TxDOT and CAR-UTSA. Permission to reprint an entire chapter, section, figures or tables must be obtained in advance from the Supervisor of the Archeological Studies Program, Environmental Affairs Division, Texas Department of Transportation, 125 East 11th Street, Austin, 78701. Copies of this publication have been deposited with the Texas State Library in compliance with the State Depository requirements.
\end{abstract}

Printed by Kwik Kopy on Main, San Antonio, Texas

December 2003

jointly published by

Texas Department of Transportation

Environmental Affairs Division

Archeological Studies Program

Owen Lindauer, Ph.D., Supervisor

Archeological Studies Program

A. McGraw, Series Editor

and

Center for Archaeological Research

The University of Texas at San Antonio

Archaeological Survey Report, No. 320

Printed on acid-free, $60 \mathrm{lb}$. paper 


\section{Abstract:}

During March through July 2003, The Center for Archaeological Research of The University of Texas at San Antonio conducted a cultural resources survey, including geoarcheological studies, along portions of State Highway 35 from Angleton to Old Ocean in Brazoria County, Texas. This survey was conducted under Texas Antiquities Permit No. 3091 and was performed for the Texas Department of Transportation, Environmental Affairs Division. During the early phases of the survey, a Historic Context for the project was developed by Hardy-Heck-Moore, Inc. of Austin, Texas. This Historic Context was used to guide the latter phases of the survey, and is reproduced in this document. The project area consisted of a 15-mile-long discontinuous portion of the highway, with variable widths and eight separate detention ponds, varying in area from 2-12 acres each. Nearly 600 auger borings, here substituted for shovel tests, and 176 backhoe trenches were excavated, encountering no significant cultural deposits or features. The artifacts uncovered during these investigations were of recent origin and, therefore, none were collected for analysis and curation. With the exception of testing at site $41 \mathrm{BO} 184$, this project completes the cultural resources inventory of the State Highway 35 corridor between Angleton and Old Ocean. 


\title{
Table of Contents:
}

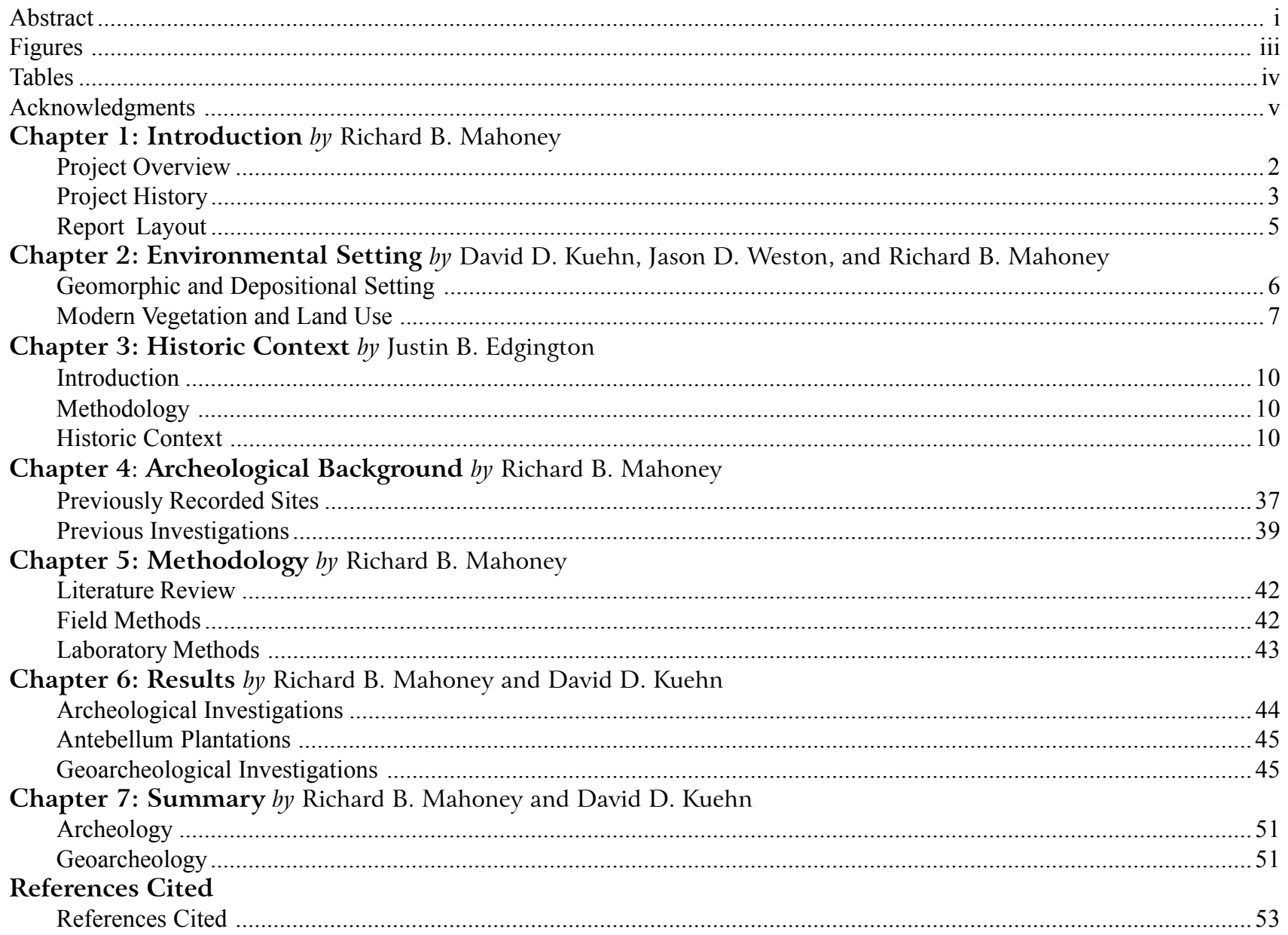

\section{Table of Contents - CD:}

\author{
Appendix A: Backhoe Trench Profiles \\ Appendix B: TxDOT Construction Map Sheets \\ Appendix C: Detention Pond Maps
}




\section{Figures:}

Figure 1-1. Location of SH 35 Brazoria County Corridor Improvements Project. ...................................................... 1

Figure 1-2. Section 1 map with location of section and detention ponds. .................................................................. 2

Figure 1-3. Section 2 map with location of section and detention ponds. ................................................................. 3

Figure 1-4. Section 3 map with location of sections and detention ponds..................................................................... 4

Figure 2-1. Typical pasture vegetation encountered along ROW. ........................................................................ 7

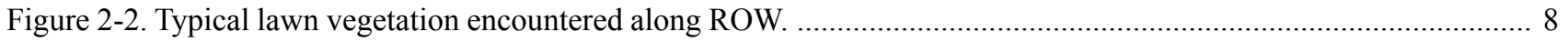

Figure 2-3. Typical dense understory vegetation encountered along ROW.............................................................. 9

Figure 2-4. Typical dense woods encountered along ROW. .................................................................................. 9

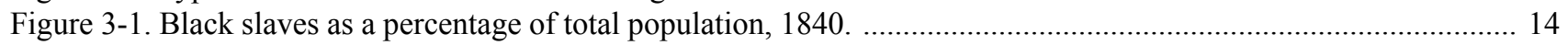

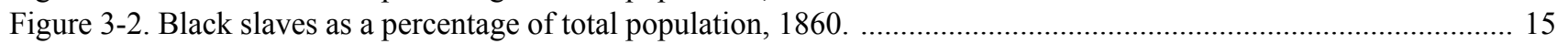

Figure 3-3. Cotton gin on the Sweeny Plantation, Brazoria County, Texas, ca. 1870 .................................................. 17

Figure 3-4. Waldeck sugar mill at Waldeck Plantation, Brazoria County, Texas. ............................................................ 19

Figure 3-5. Chenango Sugar Mill, Brazoria County, Texas. …….............................................................................. 19

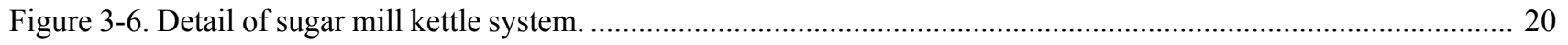

Figure 3-7. 1914 plat map showing the location of Willow Glen Plantation. .............................................................. 24

Figure 3-8. Drawing of the main residence at Ridgeley Plantation. ......................................................................... 24

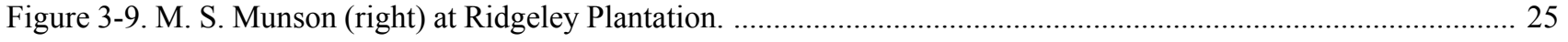

Figure 3-10. Plat map showing Abner Jackson's plantation with sugar house, residence and outbuilding. ..................... 26

Figure 3-11. Map showing a public road adjacent to a ginhouse, residence, and slave quarters.................................... 27

Figure 3-12. Drawing showing the Josiah Bell plantation, Brazoria County, circa 1830............................................. 29

Figure 3-13. Abner Jackson's plantation home at Lake Jackson, Brazoria County. .......................................................... 29

Figure 3-14. Slave cabin at Ridgeley Plantation, Brazoria County. .......................................................................... 30

Figure 3-15. Typical sugar plantation layout showing location of slave quarters...................................................... 31

Figure 3-16. Slave community at Bernardo Plantation, Brazoria County .................................................................... 32

Figure 3-17. Postbellum settlement patterns indicative of the sharecropping system. …............................................... 33

Figure 3-18. Oil, gas, and sulfur deposits in Brazoria County, circa 1940 ................................................................. 35

Figure 4-1. Number of recorded sites and modern (1990) population densities of coastal counties............................... 37

Figure 6-1. Magazine fragment (dating to the early 1970s) encountered in BHT 97. ..................................................... 45

Figure 6-2. Abandoned landfill encountered in BHT 97. ....................................................................................... 46

Figure 6-3. Locations of antebellum plantations within the area of potential effect........................................................ 47 


\section{Tables:}

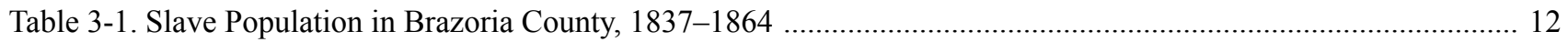

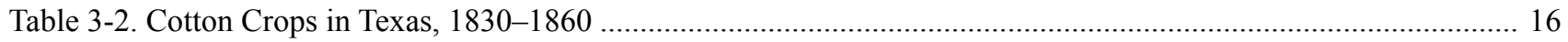

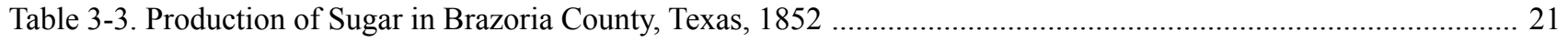

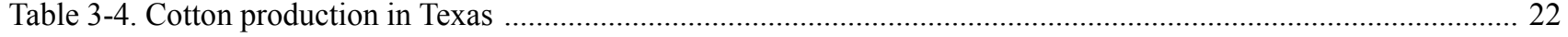

Table 4-1. Number of recorded sites, area, and population of coastal counties ......................................................... 38

Table 4-2. Previously recorded historic sites in Brazoria County ............................................................................... 40

Table 6-1. Auger borings (AB) and backhoe trenches (BHT) excavated by section .................................................... 44

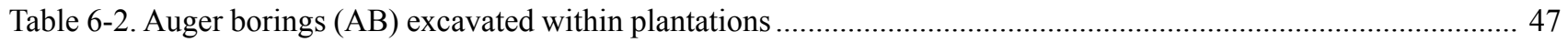




\section{Acknowledgments:}

Several individuals should here be recognized for their contributions to the completion of this project. Jim Abbott and Allen Bettis, TxDOT Staff Archeologists, were most instrumental in project organization and logistical support. Owen Lindauer, TxDOT Archeological Studies Program Supervisor, is acknowledged for facilitating CAR during the project. Mike Christley, TxDOT Engineer, was likewise helpful in logistical support at the local level. Curtis Hart, UTSA Department of Health and Kinesiology Chairman, was gracious enough to allow CAR the use of his department's trailer to tow our heavy equipment. Bruce Jensen of TxDOT's Historical Studies Branch and David Moore, HHM's Project Manager, were instrumental in overseeing preparation of the historic context. Steve Tomka and Raymond Mauldin, CAR Director and Assistant Director, respectively, provided administrative guidance and visited the project area to assess progress. The CAR survey crew consisted of Rachael Davies, Bryant Saner, Matt Senn, Stacy Wagner, and Jason Weston. Bruce Moses and Rick Young, CAR Draftsmen, are gratefully thanked for their cartographic expertise. CAR administrative support staff included Sherrilyn Suñaz, Administrative Assistant; Melanie Price-Bennett, Secretary; Mike Wright, Accountant; and Maribel Ortiz, Student Clerk. Finally, Johanna Hunziker, CAR Editor, is thanked for her assistance in production of the final version of this report.

Cover illustration adapted from Allen A. Platter, "Educational, Social, and Economic Characteristics of the Plantation Culture of Brazoria County, Texas," 1961. 



\section{Chapter 1: Introduction}

\section{Richard B. Mahoney}

This report presents the results of intensive archeological survey along State Highway 35 (SH 35) between Angleton and Old Ocean in Brazoria County, Texas (Figure 1-1). The field efforts were conducted during March through July 2003 by the Center for Archaeological Research (CAR) of The University of Texas at San Antonio under contract with the Texas Department of Transportation (TxDOT). The purpose of the survey was to complete the cultural resources inventory by locating and defining cultural resources to be impacted within the Area of Potential Effect (APE) of the expanded rights-of-way through the proposed development of SH 35. The survey was performed under Texas Antiquities Permit Number 3091, with Steve Tomka, CAR Director, serving as Principal Investigator.

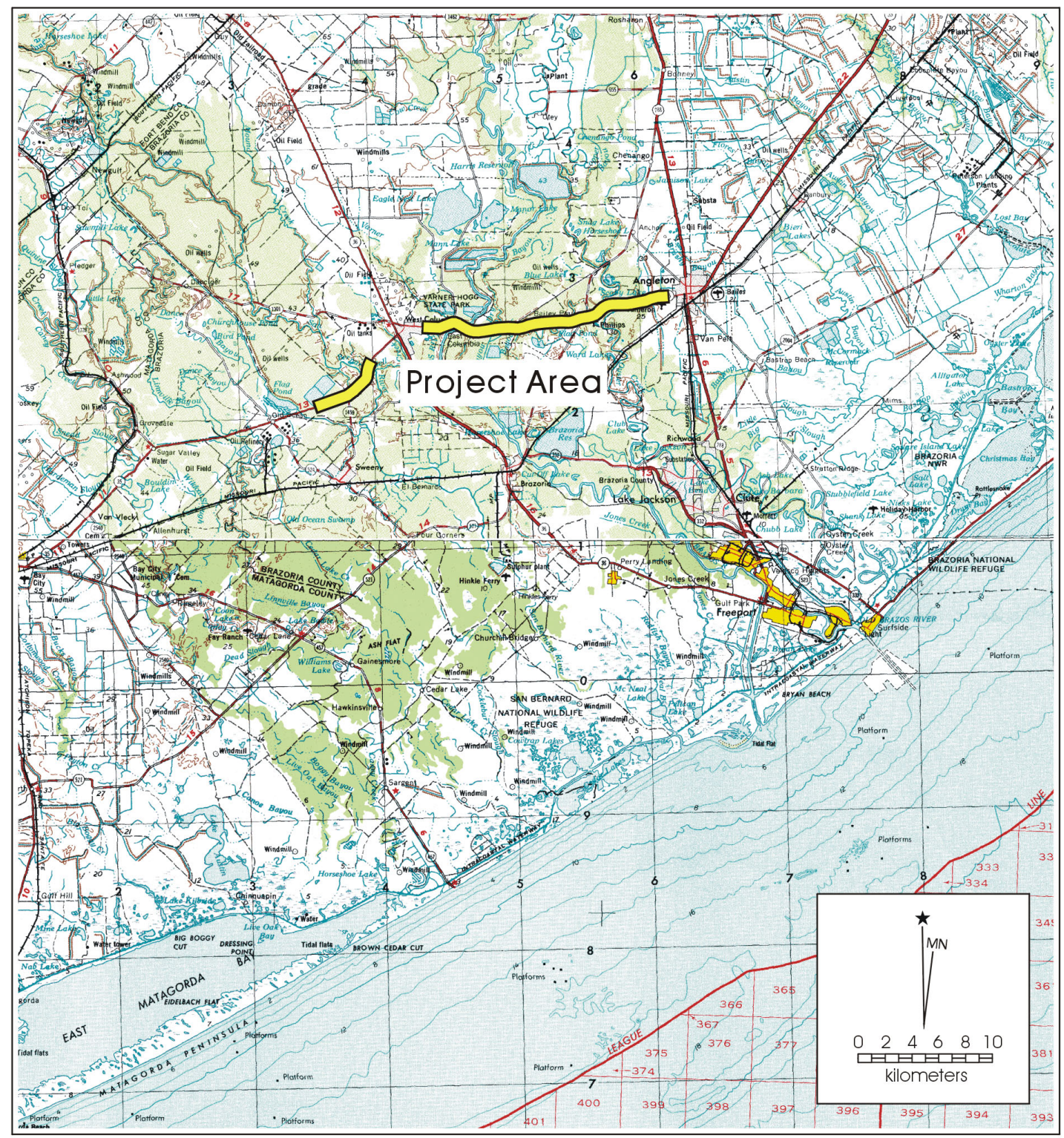

Figure 1-1. Location of SH 35 Brazoria County Corridor Improvements Project. 


\section{Project Overview}

The intensive survey, the subject of this report, is a component of the SH 35 Corridor Improvements Project, a highway improvement project covering approximately 30 miles between the cities of Van Vleck in Matagorda County and Angleton in Brazoria County. The survey discussed in this report stretches in a general east-west direction from the city of Angleton to the vicinity of Old Ocean. The subject of this survey is an approximate 15-mile-long right-of-way (ROW) between these two cities. The existing SH 35 is a two-lane, undivided rural facility with shoulders and open ditches. The existing ROW ranges from $100-120$ feet in width. The proposed corridor improvements will result in the construction of a four-lane, divided facility with a grass median. Associated with the proposed ROW widening are a total of eight detention ponds constructed at various points along the ROW.
The project is located in the southwestern portion of Brazoria County (see Figure 1-1) and is contained on four different USGS quadrangle maps. These USGS 7.5' maps are the Angleton (2995-123), East Columbia (2995-214), West Columbia (2995-213), and Sweeny (2995-212) quads. The variability in the APE width is depicted on TxDOT construction Map Sheets 1-46 (Appendix B). These maps identify the final area subject to intensive survey.

Due to variable letting dates and to facilitate the completion of the cultural resources inventory, the project area was divided into three sections, with the third section subdivided as "a" and "b." Figures 1-2 through 1-4 present the overall section maps of the project area, with sections and detention ponds highlighted. Each of these sections is briefly described. Section 1 (Figure 1-2) extends from STA 205+00 to STA 505+00 (SH 521 to Brazos River) and includes five associated detention ponds (Nos. 3, 5, 6, 7, and 8). The

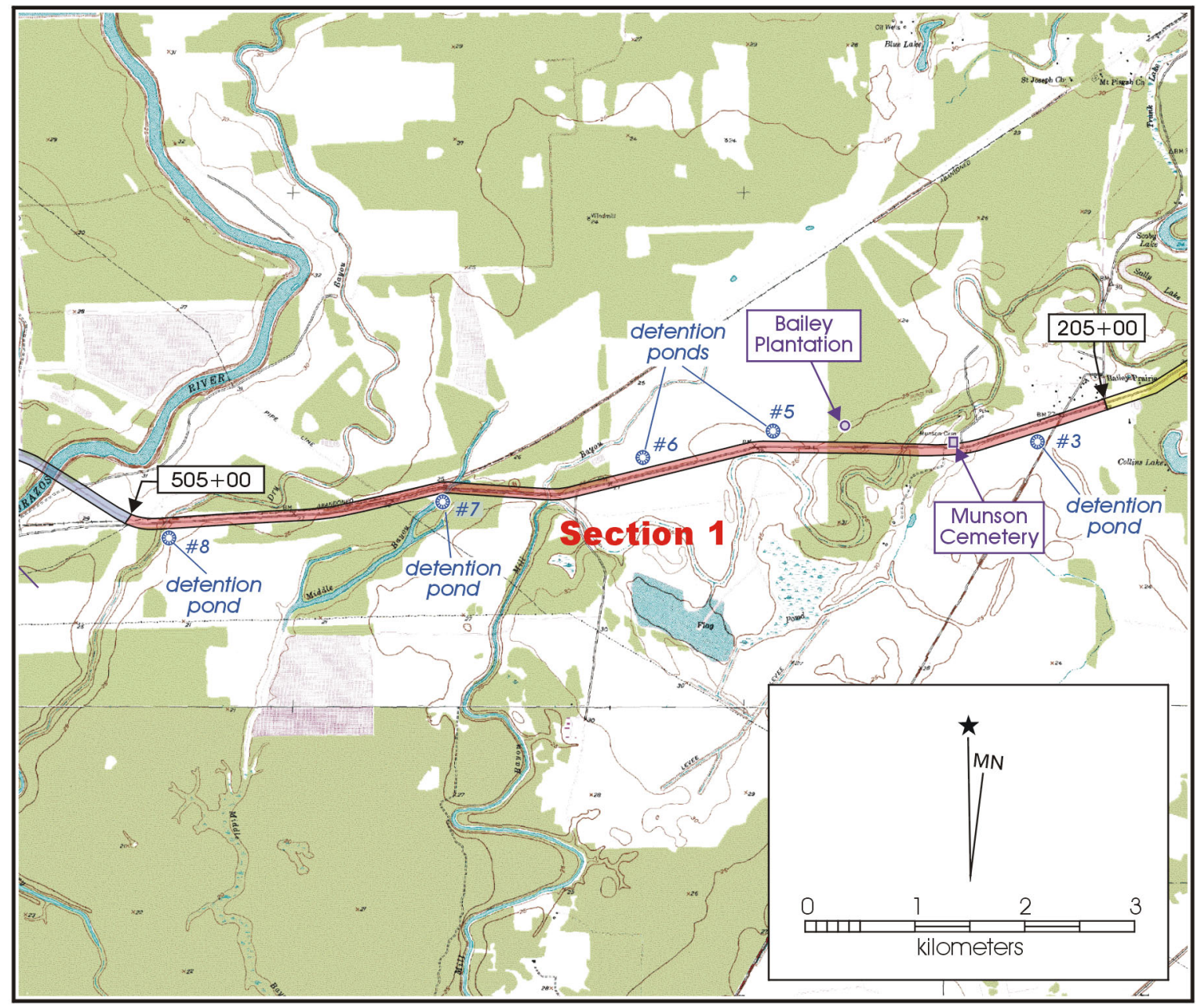

Figure 1-2. Section 1 map with location of section and detention ponds. 


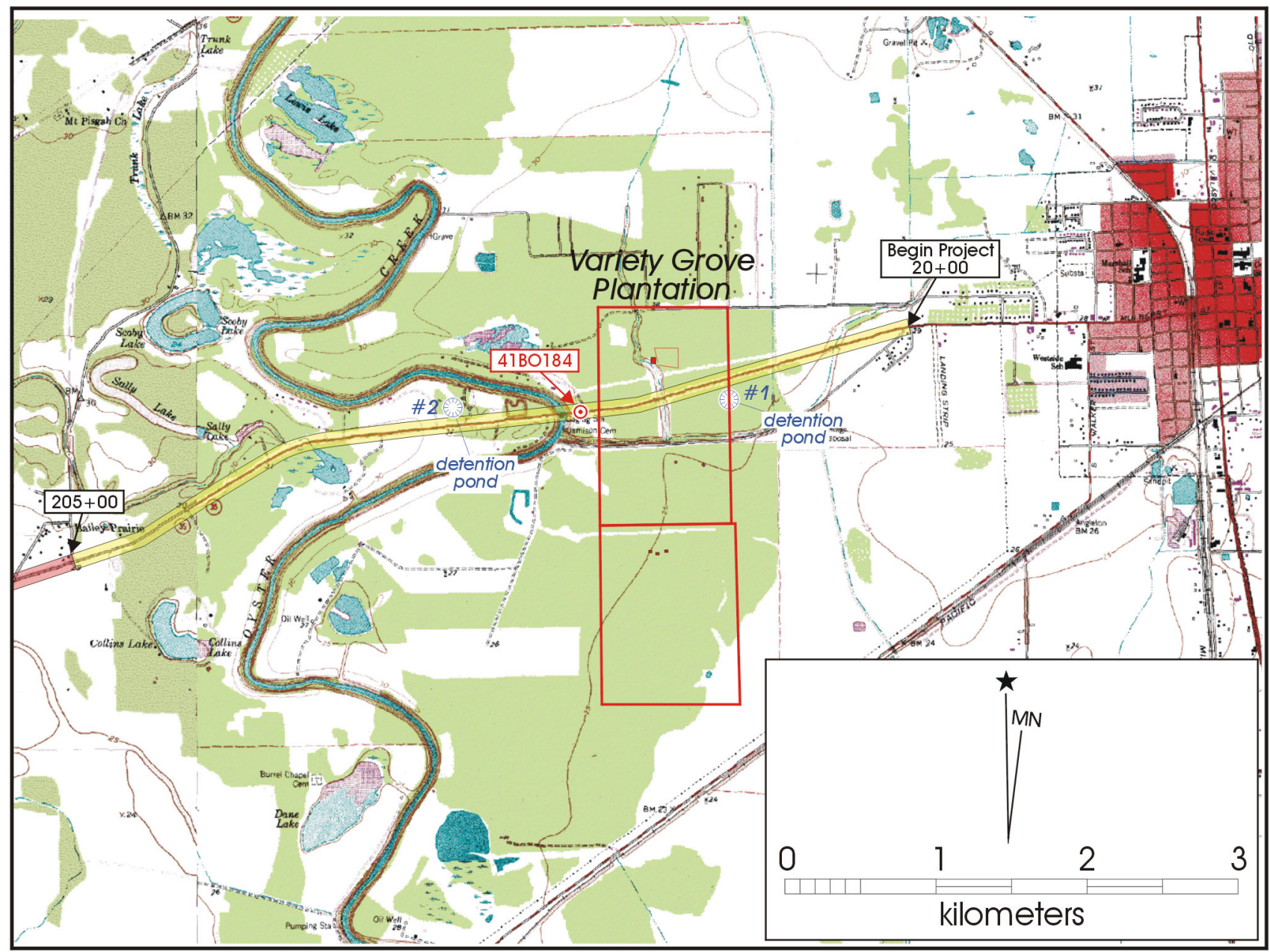

Figure 1-3. Section 2 map with location of section and detention ponds.

total section length is just over 9,140 meters, or 30,000 feet. The five detention ponds are approximately 5.3 acres (No. 3), 5.6 acres (No. 5), 15.2 acres (No. 6), 12.7 acres (No. 7), and 10.8 acres (No. 8). Section 2 (Figure 1-3) extends between STA 20+00 to STA 205+00 (SH 288 to SH 251), and has two associated detention ponds (Nos. 1 and 2). Section two has a total length of roughly 5,640 meters, or 18,505 feet. Detention Pond No. 1 covers roughly 6.9 acres, and Detention Pond No. 2 covers about 2.5 acres. Section 3 (Figure 1-4) is composed of Section 3a and Section $3 b$. Section $3 \mathrm{a}$ extends between STA 505+00 and STA 605+00 (between Brazos River and West Columbia) and Section $3 \mathrm{~b}$ extends between STA $823+00$ and STA 10,400+00 (between two bypasses). One associated detention pond, No. 9, is present along Section 3b. Detention Pond No. 9 covers roughly 12.2 acres. The total project area subject to survey is roughly 24,175 meters (79,318 feet) in length.

\section{Project History}

Archeological survey for the development of SH 35 in this portion of Brazoria County has spanned nearly a decade prior to the production of this report. In 1994, then TxDOT Staff Archeologist Chris Ward conducted the first survey of the proposed SH 35 development. In her survey, she identified two previously unrecorded archeological sites, 41BO184 and 41BO185. At that time, 41BO184 was interpreted as a prehistoric site of unknown temporal affiliation, and 41BO185 was interpreted as a historic site, likely associated with mid- to late-nineteenth-century occupations.

In subsequent investigations at site 41BO185 during 1999, then TxDOT StaffArcheologist Diane Dismukes conducted National Register of Historic Places (NRHP) and State Archeological Landmark (SAL) testing (Dismukes 2003). 


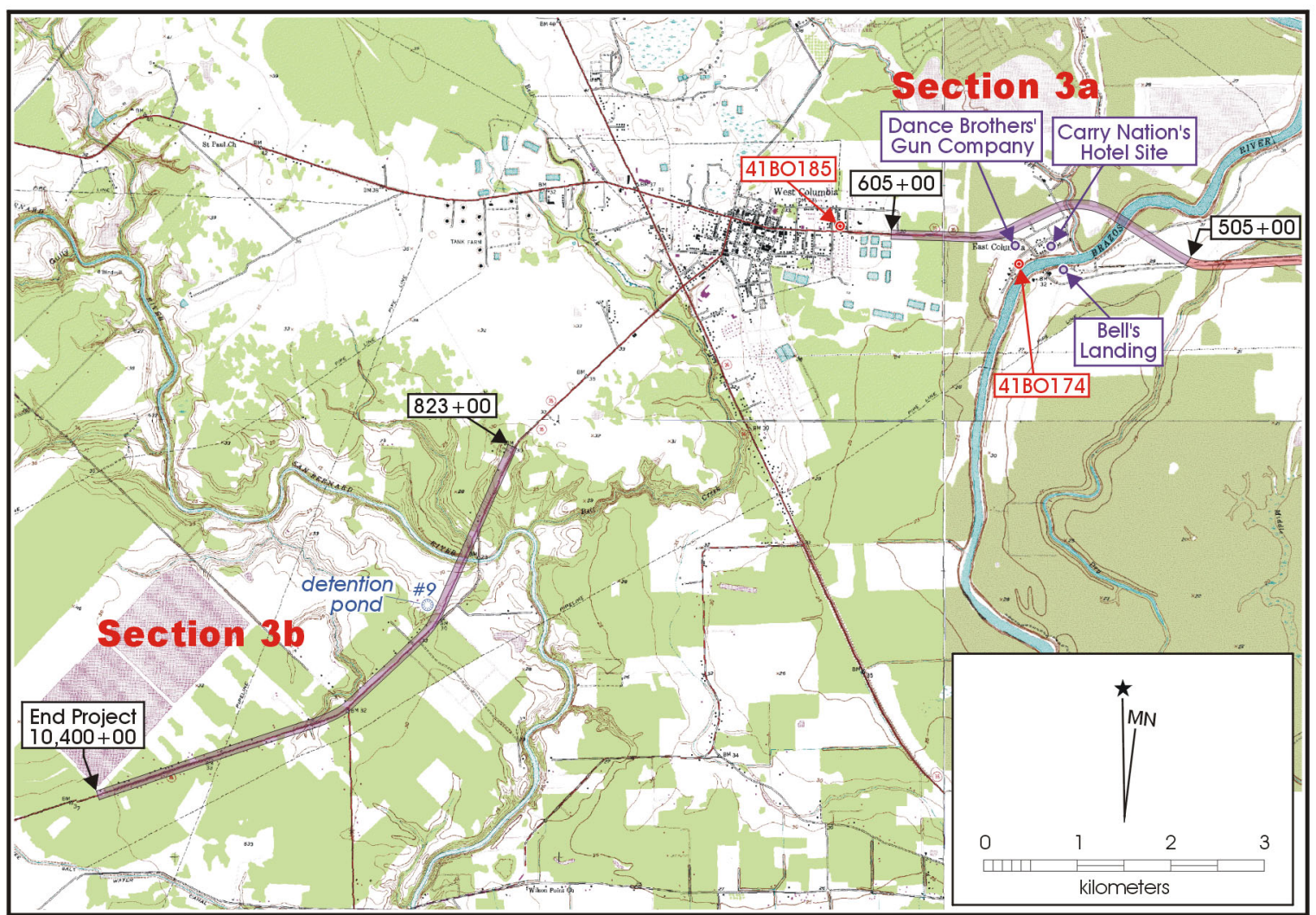

Figure 1-4. Section 3 map with location of sections and detention ponds.

The results of her fieldwork and research revealed a possible Civil War era military encampment with probable postbellum and post-1900s components. The site, however, was determined ineligible for listing on the NRHP or SAL designation.

During 2001, TxDOT Staff Archeologist Allen Bettis returned to site 41BO184 for further investigation. While only a single lithic flake and a few aboriginal ceramic sherds were recovered during his fieldwork, a discrete historic component was identified, occurring at $20-40 \mathrm{~cm}$ below surface (Allen Bettis, personal communication 2003). Cursory analysis of the recovered historic artifacts suggested antebellum affiliation.

In 2003, CAR continued site definition at 41BO184 with intensive mechanical auger excavations (Mahoney 2003a). A total of 36 auger borings was dug to $120 \mathrm{~cm}$ below surface (bs) on a 5-m grid across the previously delimited site bounds. A single lithic flake was recovered in a disturbed and/or redeposited context, and a discrete prehistoric component could not be defined. Conversely, several additional historic artifacts were recovered, providing a mean date for the site at roughly 1859 .

Concomitant with CAR's field survey, Hardy-Heck-Moore, Inc. (HHM) of Austin conducted archival research to determine the location and nature of potential antebellum plantations within the APE. Through their research, HHM located three plantations, portions of which will be impacted with the proposed ROW expansion (HHM 2003 and Chapter 3 , this report). As expressed within the APE, the following portions of the plantations will be impacted along SH 35: Variety Grove Plantation ( $880 \mathrm{~m}$ long and $34 \mathrm{~m}$ wide; 3.0 ha [7.4 ac]); Bailey Plantation ( $900 \mathrm{~m}$ long and $40 \mathrm{~m}$ wide; $3.6 \mathrm{ha}$ [8.9 ac]); and Willow Glen Plantation ( $870 \mathrm{~m}$ long and $54 \mathrm{~m}$ wide; $4.7 \mathrm{ha}$ [11.6 ac]). 


\section{Report Layout}

This report is comprised of seven chapters and three appendices. Following this introductory chapter, Chapter 2 presents the environmental setting for the project area, discussing the geomorphic and sedimentary depositional settings and the modern vegetation. Chapter 3 describes the historic context for the project area. Chapter 4 reviews the archeological background for the area, including previously recorded archeological sites and previous archeological investigations. Chapter 5 discusses the methodology employed for the survey, including the background literature review and the field and laboratory methods. Discussion of the field methods includes aspects of the pedestrian survey, mechanical auger boring, and backhoe trenching. Chapter 6 details the outcome of the archeological and geoarcheological fieldwork. Chapter 7 summarizes the current project and offers management recommendations. Appendix A is comprised of representative backhoe trench profiles and is tied to the geoarcheology results presented in Chapter 6. Appendix B contains all of the project specific maps (Map Sheets 1-46), and Appendix C contains the Detention Pond maps (Pond Nos. 1, 2, 3, 5, 6, 7, 8, and 9) supplied by TxDOT. All appendices are contained on the CD-ROM enclosed in the pocket at the back of this volume. 


\title{
Chapter 2: Environmental Setting
}

\author{
David D. Kuehn, Jason D. Weston, and Richard B. Mahoney
}

The overall project area is located in the south-central portion of Brazoria County, in the Upland Prairies and Woods Natural Region of the West Gulf Coastal Plain physiographic area. The climate of the area is sub-tropical humid. Precipitation is bimodal, with rainfall peaks in late spring and late summer/early fall (Bomar 1995). At Angleton, just to the east of the survey, precipitation averages 56.41 inches $(143 \mathrm{~cm})$ a year, with peaks in June (6.26 in) and September (7.29 in). July and August are the warmest months, with average monthly high temperatures exceeding $90^{\circ} \mathrm{F}$, and January is the coldest month, with average low temperatures around $40^{\circ} \mathrm{F}$ (Bomar 1995).

\section{Geomorphic and Depositional Setting}

The SH 35 road improvement project is located in the Coastal Prairies sub-province of the Gulf Coastal Plains physiographic province (Bureau of Economic Geology 1996). The region is identified as the Atlantic and Gulf Coastal geomorphic province by Walker and Coleman (1987). The subaerial portion of the Atlantic and Gulf Coastal province is termed the Coastal Plain (Walker and Coleman 1987:51-52).

The low-relief Coastal Plain is comprised of seawardoriented marine, fluvial, fluviodeltaic, and eolian sediments of Cretaceous through Quaternary age (Angel 2002; Bureau of Economic Geology 1992; Dupre 2002; Walker and Coleman 1987). Rocks and unconsolidated sediments exposed subaerially in the Coastal Plain region include (from oldest to youngest): the Fleming Formation (Miocene) mud and sand; the Willis Formation (Pliocene and early Pleistocene) - Qwl and Qwc — mud, sand, and gravel; the Lissie Formation (Pleistocene) - mud, sand, and gravel; the Beaumont Formation (middle to late Pleistocene) mud and sand; the Deweyville Terrace (late Pleistocene) cut terrace(s) along valley walls; and post-Deweyville (Holocene) - extant stream and delta mud, sand, and gravel (Abbott 2001; Angel 2002; Barnes 1968; Blum et al. 1995; Bureau of Economic Geology 1992; Dupre 2002).

All three SH 35 project sections are situated in the lower reaches of the Brazos and Brazos/Colorado river floodbasins. As such, virtually all late Quaternary sediments within the project area are the product of fluvial depositional processes operating within a meandering stream environment. These sediments reflect channel bed, channel margin, and overbank/floodplain facies. Channel bed facies include lag deposits and point bar sediments; channel margin facies include natural levee and crevasse-splay deposits; while floodplain facies are frequently represented by lowrelief vertical accretion sediments, oxbow lakes, and backswamps (Baker et al. 1987; Bernard et al. 1970; Boggs 1987; Walker and Cant 1984).

In addition to the Brazos River, which flows through a modern meanderbelt located near the eastern end of Section $3 \mathrm{a}$, the SH 35 project area also contains two prominent tributaries of the Brazos River and a second perennial river, the San Bernard. The prominent Brazos River tributaries are Oyster Creek (near the eastern end of Section 1) and Varner Creek (near the eastern end of Section 3). Oyster Creek is situated along the eastern side of the Brazos Valley and flows through an extensive meanderbelt associated with a former channel of the Brazos River. The Brazos River abandoned this channel during an avulsion event that occurred between about 500 and 1500 years BP (Abbott 2001:123; Bernard et al. 1970). Varner Creek is a small tributary stream that crosses the SH 35 ROW a short distance west of the Brazos River crossing.

The San Bernard River crosses SH 35 southwest of West Columbia in Section 3b. The San Bernard is apparently associated with the ancestral Colorado River and is located along the eastern side of the now-filled Colorado River valley (Abbott 2001; Blum et al. 1995). The association between the San Bernard and the Colorado rivers is somewhat problematic due to incongruent geologic maps of the region (Abbott 2001:126-128; Barnes 1968; Blum 1992; McGowen et al. 1976).

Other streams in the project area include Mill Bayou (which crosses the SH 35 ROW in Section 1) and Middle Bayou (near the western end of the SH 35 project area). In addition, a number of inundated oxbow lakes, including Scobie Lake, Salley Lake, and Collins Lake, are located northeast and southeast of Section 1, while low-lying swampy areas occur throughout much of the region. 
Recent geomorphological, sedimentological, and geoarcheological investigations in the SH 35 project area were conducted by TxDOT geoarcheologist James Abbott (Abbott 2001). A series of deep hollow tube cores were collected from the SH 35 ROW between the communities of Angleton and West Columbia (Abbott 2001). The cores revealed upward-fining point bar sequences in the Oyster Creek meanderbelt, complex sequences of thick, late Pleistocene to late Holocene deposits in the western portion of the project area, and middle to late Holocene veneers over late Pleistocene and Beaumont Formation materials in other portions of the project area (Abbott 2001:116-122). The coring effectively demonstrated that Holocene and late Pleistocene-aged fluvial deposits are extant at depths in excess of $15 \mathrm{~m}$ below the present surface. The documented potential for deep Holocene sediments and, therefore, deeply buried archeological components was a primary impetus for the current backhoe trench investigations.

The Geologic Atlas of Texas (Bureau of Economic Geology 1996) maps the soils within the project area as Quaternary Alluvium, undivided (Qal) and Quaternary Soils (Qb); both are of the Pleistocene Beaumont Formation. More specifically, Abbott (2001:Table 2) defines the sediments of this section as alluvial Holocene deposits dominated by Hatliff and Nahatche series that fall within two orders: Mollisols and Entisols. margin environment. Native grasses are identified as Bluestem Grasslands (Abbott 2001:Figure 4), with maintained lawns comprised primarily of St. Augustine. Dense stands of woods account for approximately $6 \%$ (550 linear meters, or 1,800 linear feet) of the section's vegetation and are composed mostly of pecans and elms forming a Pecan/ Elm Forest (Abbott 2001:Figure 4). The woods occur as isolated stands in several areas and are composed of mostly old, mature trees. Lastly, dense brushy areas account for roughly $8.2 \%$ (750 linear meters, or 2,460 linear feet) of the area and consist of various briars, weeds, and dewberries. These vegetation settings are not contiguous, but rather intermixed with each other, alternating from grasses to stands of trees to brushy areas over the length of the ROW.

The land use ranges from pastures to well-manicured lawns and commercial/light industrial along the Section 1 ROW. Grasslands, either pasture or mown lawns, comprise an estimated $85.8 \%$ ( 7,850 linear meters, or 25,740 linear feet) of the Section 1 project area. Figure 2-1 depicts a typical pasture encountered along the project area.

\section{Section 2}

Similar to Section 1, the entirety of Section 2 is in the floodplain of the Brazos River and possesses vegetation consistent with a floodplain and/or floodplain margin

\section{Modern Vegetation and Land Use}

The following discussion details the vegetation of each individual section of the overall project area. While the above geomorphic setting applies generally to the south-central portion of Brazoria County, the following is projectspecific and refers to the three sections within the project area.

\section{Section 1}

The entirety of Section 1 is in the floodplain of the Brazos River and possesses vegetation consistent with a floodplain and/or floodplain

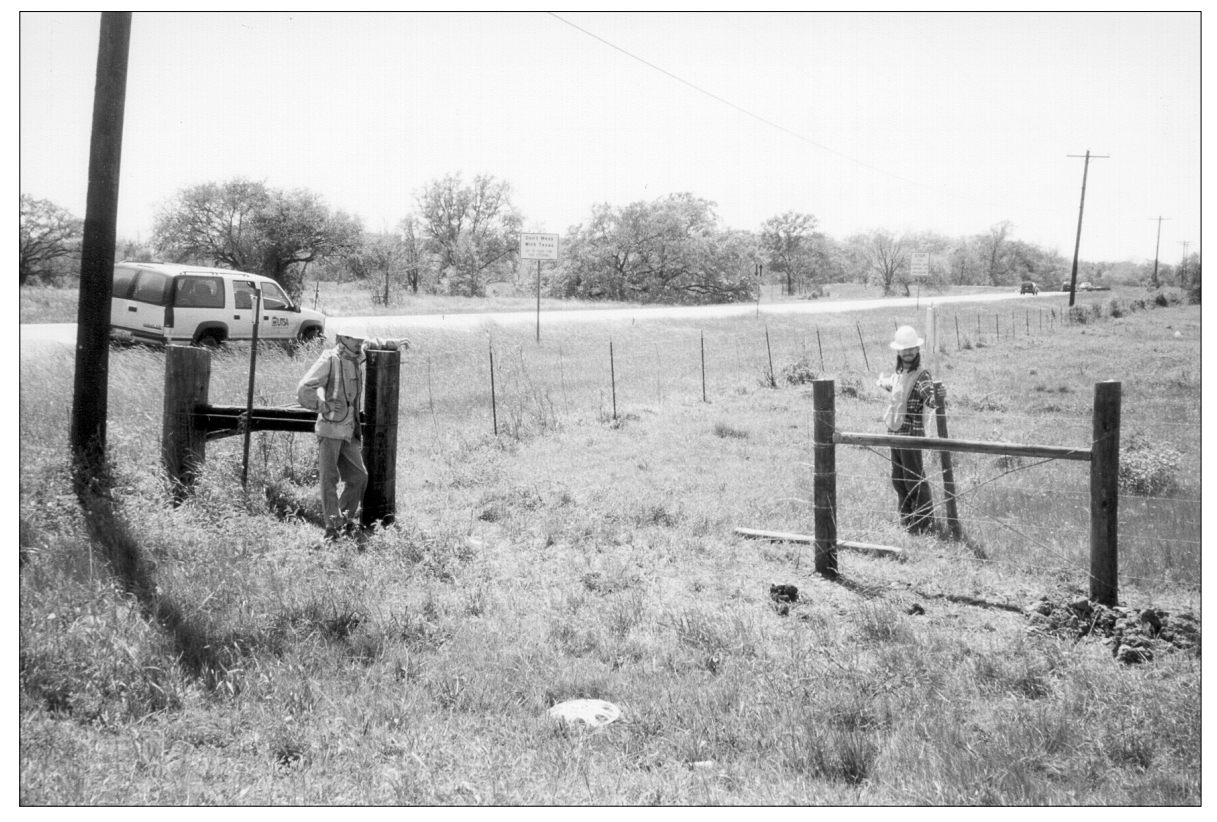

Figure 2-1. Typical pasture vegetation encountered along ROW. 
environment. Native grasses are identified as Bluestem Grasslands (Abbott 2001:Figure 4), with maintained lawns comprised primarily of St. Augustine. Dense stands of woods account for approximately $35.1 \%$ (200 linear meters, or 6,500 linear feet) of the section's vegetation and are composed mostly of pecans and elms forming a Pecan/Elm Forest (Abbott 2001:Figure 4). The woods occur as isolated stands in several areas of pasture and lawn and are composed of mostly old, mature trees. These two vegetation settings are not contiguous, but rather are intermixed with each other, alternating from grasses to stands of trees over the length of the ROW.

The land use in Section 2 can be divided into two categories: pasture (including some wooded areas and fallow grasslands) and lawn (mown grassy areas that are not pasture land). Grasslands, either pasture or mown lawns, cover an estimated 64.9\% (3,660 linear meters, or 12,000 linear feet) of the Section 2 project area. An example of a typical lawn is shown in Figure 2-2.

\section{Section 3}

The majority (61\%) of Section 3 is in the floodplains of the Brazos or San Bernard rivers. The remainder (39\%) occurs in the upland, west of the San Bernard floodplain. More specifically, Section 3a is contained wholly within the Brazos River floodplain, $41 \%$ of Section $3 \mathrm{~b}$ is in the San Bernard floodplain, and $59 \%$ of Section $3 \mathrm{~b}$ occurs in the upland. Grasslands, either pasture or mown lawns, comprise approximately one-third of the Section 3 project area. Dense stands of woods and cleared areas now dominated by dense understory vegetation account for the remainder of the section's vegetation and are composed mostly of pecans and elms. The woods occur as dense stands in several areas and are composed of mostly old, mature trees. Dense brushy areas of secondary growth occur within the wooded portions of the project area and represent the former location of numerous structures, now removed from the expanded ROW.

The land use in Section 3 can be divided into two categories: pasture (including some sparsely wooded areas) and lawn (mown grassy areas that are not pasture land). Dense understory vegetation (Figure 2-3), and dense woods (Figure $2-4)$ dominate the remainder of the section.

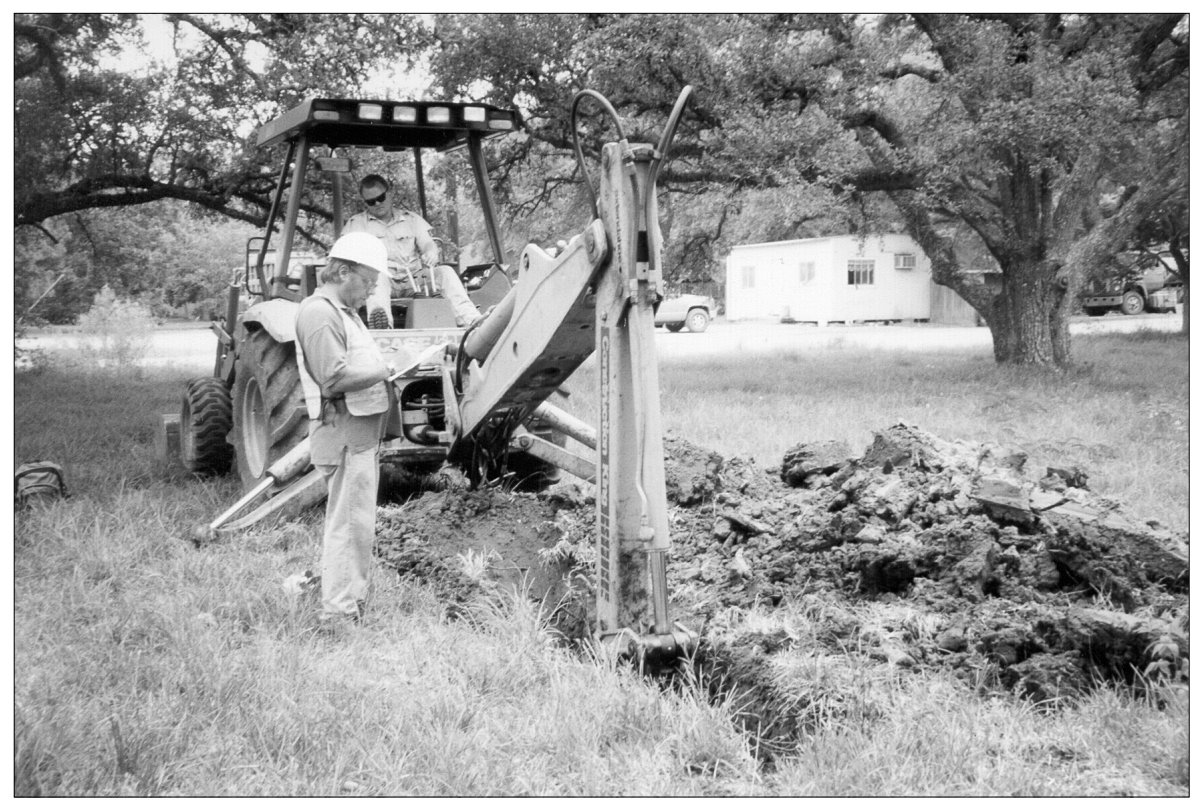

Figure 2-2. Typical lawn vegetation encountered along ROW. 


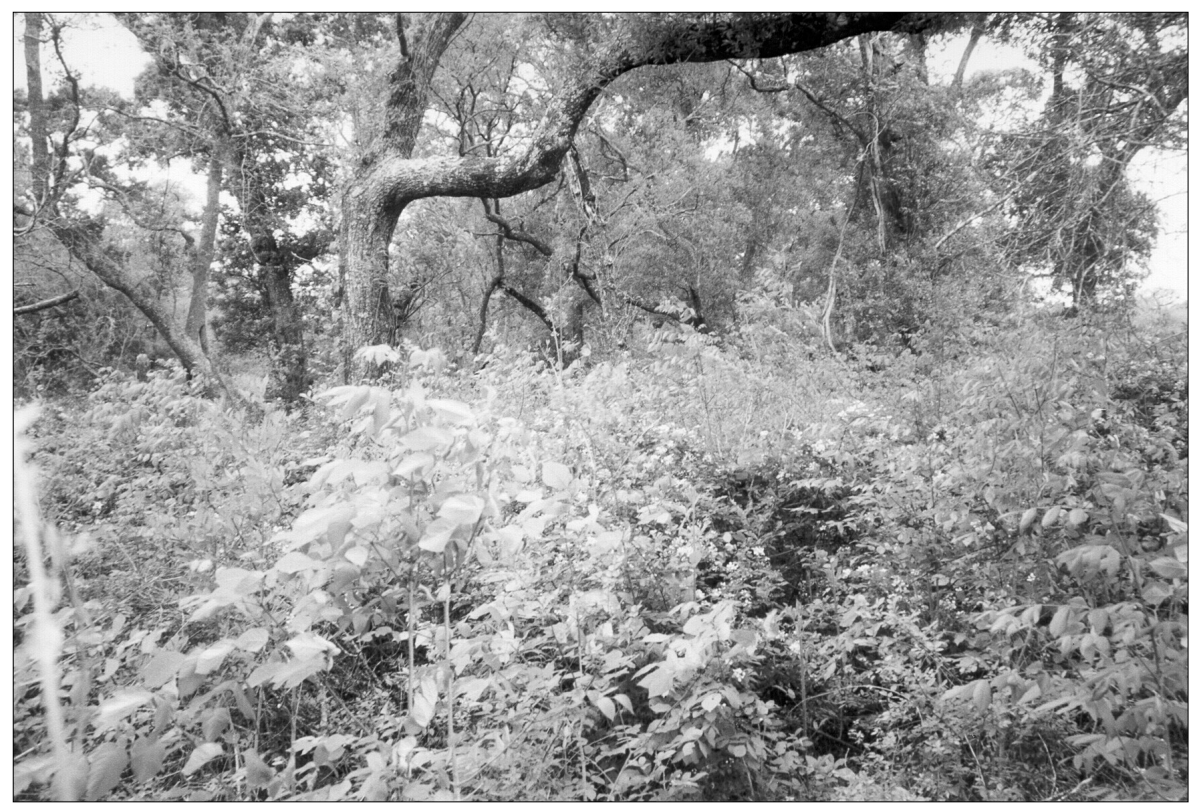

Figure 2-3. Typical dense understory vegetation encountered along ROW.

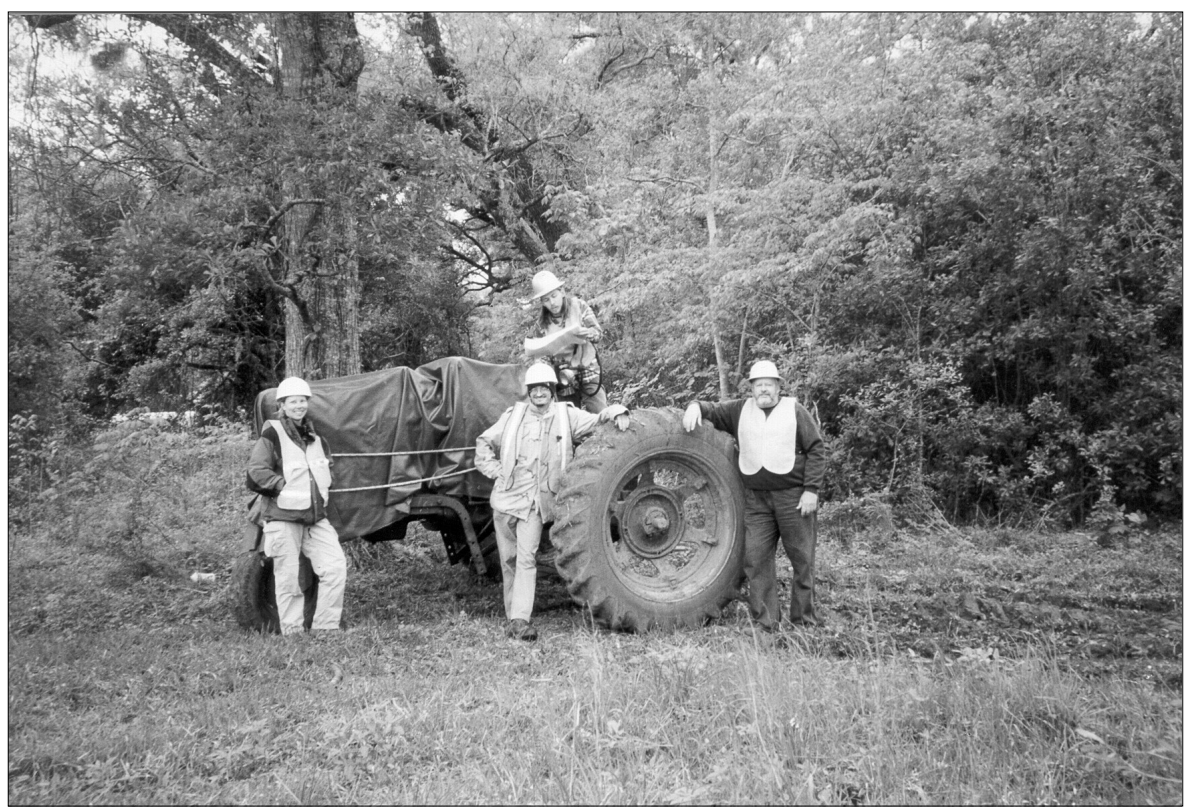

Figure 2-4. Typical dense woods encountered along ROW. 


\title{
Chapter 3: Historic Context
}

\author{
Justin B. Edgington
}

\section{Introduction}

In March 2003, TxDOT directed HHM, Inc. to conduct historical and archival research to aid cultural resource investigations along SH 35 in Brazoria County, Texas. The project area follows a mile-wide corridor along SH 35 between the Matagorda County line and SH 288 in Angleton, Texas. TxDOT tasked HHM with three objectives: 1) prepare a research design and preliminary assessment that examine both primary and secondary source material and consider how valuable these sources will be for the purpose of identifying potential locations of historic archeological sites along SH 35, as well as developing a historic context for Brazoria County; 2) identify potential locations of historic archeological sites within the project area based on the results of the archival research; and 3) develop a historic context for the project area that examines broad trends and patterns in local history and focuses on the development of the local plantation system and the establishment of freedmen's communities during the Reconstruction era. This chapter meets the requirements of the third objective by providing a historic context for the project area which examines historical trends, individuals, and events in Brazoria County before 1875 . The chapter emphasizes the role of the local plantation system and the development of freedmen's communities in the years following the Civil War. In addition, the chapter documents the rise of the local petrochemical industry in the early twentieth century in relation to its potential effects on historic resources in the project area.

\section{Methodology}

The HHM project team for the SH 35 archival research project included David Moore, project supervisor, and Justin Edgington, historian. HHM staff conducted archival research for the project from March 7 through May 23, 2003, following initial consultation with TxDOT personnel in Austin. Archival research related to the preparation of a historic context occurred in both Austin and Angleton, Texas.

The HHM historian visited repositories in Austin including the Perry-Castañeda Library, General Land Office, the Center for American History at the University of Texas at Austin, and the Texas State Library and Archives. The research items collected at these repositories included diaries, deeds, letters, USGS maps, published primary accounts, agricultural, population, and slave schedules of the 1850 and 1860 censuses, and ad valorem records for individual plantation owners. In Angleton, the HHM historian visited the Brazoria County Courthouse, Engineer's Office, and Historical Museum. These repositories house deeds, plat maps, wills, transportation records, historic county maps, aerial photographs, and other historic material related to Brazoria County.

\section{Historic Context}

\section{Early Anglo-American Settlement of Brazoria County}

In an effort to stem the effects of hostile Indian tribes in Texas, the Spanish government in the early 1820 s actively encouraged Anglo-American settlers to colonize the vast region. In 1821, Moses Austin negotiated a permit with the Spanish to bring 300 Anglo-American families to Texas. His death shortly after, however, resulted in his son, Stephen F. Austin, taking over responsibility for the proposed colony. After negotiating changes to the permit related to Mexico's recent independence from Spain, Austin gathered 300 families and began the process of establishing the colony. According to the colonization agreement, each family was to receive a sitio (about 4,428 acres) and a labor (177 acres) of land. Austin selected the bottomlands of the Brazos, Colorado, and San Bernard rivers as the site for his colony. Many of the colonists selected sites facing the eastern bank of the Brazos River. Of the colonists who settled in what is present-day Brazoria County, most were born east of the Appalachian Mountains and brought with them the traditions and institutions of that region, including slavery (Kleiner 2003a).

One of the first settlers to arrive in Brazoria County was Josiah H. Bell, a planter from the Missouri Territory and Louisiana. Arriving at Washington-on-the-Brazos in 1821, Bell moved his family and slaves to present-day Brazoria County in 1823 . He established a large plantation at the site of his newly appointed league of land on the west side of the Brazos River. Bell quickly established himself as a prominent figure in the colony; Austin selected him to oversee the colony's affairs during Austin's visit to Mexico 
in 1822-23. Bell was also influential in the development of two important town sites in Brazoria County, Marion and Columbia (now East Columbia and West Columbia). The community of Marion, also referred to as Bell's Landing, became an important site for trade and commerce in the region. ${ }^{1}$

James Briton Bailey, a farmer born in North Carolina, settled in Brazoria County after living in Kentucky and Tennessee. Having purchased land from the Spanish government in 1818, Bailey was one of the few settlers living in Texas before the arrival of Austin's Colony. Bailey, his family, and six slaves established a small cotton farm on a large tract of land. Like many small farmers in the early years of settlement, Bailey faced a hostile environment. He went on to become an influential member of the region (Weir 2003).

By the middle of 1824 , the majority of the 300 families associated with the colony were in Texas. The region continued to attract eastern farmers eager to head west in search of cheap land and agricultural opportunities. By late 1825 , the colony counted 1,800 colonists. The colonists spread throughout Brazoria County and, in addition to Marion and Columbia, established the communities of Brazoria, Velasco, Quintana, and Liverpool.

\section{Brazoria County and Independence from Mexico}

The rapid growth of Brazoria County and the AngloAmerican settlement of Texas soon created difficulties with Mexican authorities. Relations between Mexico and AngloAmerican settlers remained tenuous, with both sides wary of the other. The Mexican government's direct attempts to maintain control over the affairs of Texas angered most settlers who desired a level of autonomy that would protect individual and property rights. In addition, most settlers retained the Southern morals, traditions, and practices of their origin, rather than accepting Mexican citizenship. Mexico, at the same time, began to fear the rapidly growing Anglo presence in the region. In fact, authorities feared that the presence of so many American settlers in Texas would cause the United States to eventually annex the region, a development Mexico was determined to prevent.

To stem American immigration to the region, in 1827 the Mexican government passed legislation prohibiting the future introduction of slaves into Texas. Texas settlers circumvented the law by classifying their slaves as indentured servants bound by contract. As a result, the growth of slavery in the state continued. Mexico took further steps in 1830 to assert control over Texas. A new law forbade further immigration from the United States, established the employment of Mexican troops in Texas, and called for customs duties on the economic activities of the settlers. Tensions increased, and in 1832 two skirmishes at Anahuac and Velasco demonstrated the rising anger of settlers against Mexican authority. Brazoria County, which in 1832 became its own municipality with Brazoria as its capitol, served as the political epicenter for much of the colony's growing insistence for independence from Mexico (Campbell 1989:26-30).

Despite a devastating flood, followed by a deadly cholera epidemic in 1833, Brazoria County continued to see an increase in white settlement and slavery. In 1834, the new president of Mexico, Santa Anna, began to exercise centralized control over the country, especially the region of Texas. Further skirmishes between the settlers and the Mexicans occurred in early 1835 as a result of the Mexican government collecting duties. By early summer, colonists became so convinced of the need for independence that they planned fall conventions in Brazoria County. Members of the conventions, including Brazoria County farmers Josiah Bell and John Sweeny, prepared for war with Mexico and began preparations for an army, a constitution and a declaration of independence (Campbell 1989:38-40).

Colonists meeting at Washington-on-the-Brazos declared independence from Mexico and wrote a constitution creating the Republic of Texas. However, news of the defeat at the Alamo and the massacre at Goliad quickly dampened their spirits. But a month later, Texas troops under the command of General Sam Houston ended their eastern retreat and surprised the Mexican army led by General Santa Anna at San Jacinto on April 21, 1836. Brazoria County played a crucial role in the victory by contributing much needed men and materials. The battle of San Jacinto established the independence of Texas from Mexico. Shortly after, Brazoria County hosted the Treaty of Velasco, which established peace terms and negotiated Mexico's formal recognition of the Republic of Texas. The selection of Columbia as the capital of the young republic verified Brazoria County's important political role during the war for independence (Campbell 1989:42-43).

\footnotetext{
1 "Josiah Bell," Vertical Files, Brazoria County Historical Museum, Angleton, Texas.
} 
By October 1836, the provisional government at Columbia began to take shape; Texans selected General Houston as President, and Stephen F. Austin and Henry Smith as Secretary of State and Treasury, respectively. The new congress carried on the business of the republic in two neighboring houses, with sheds as committee rooms. On December 20, 1836, the Congress of the Republic of Texas established Brazoria County as one of 23 counties. A year later, Columbia's brief tenure as the capital of the Republic of Texas came to an end, when congress selected the growing city of Houston as the new capital. ${ }^{2}$

\section{The Growth of Slavery in Brazoria County, 1824-1861}

Independence from Mexico allowed the settlers to actively pursue economic interests without threats against personal property. Nowhere was this issue more evident than with slavery. While not the main catalyst for the Texas Revolution, slavery undoubtedly fueled many of the colonists' complaints against Mexican rule. An examination of slavery's rapid growth during the antebellum period illustrates the institution's vital importance in Brazoria County's history.

As many of the early settlers came from the South and brought their slaves with them, the slave population in Texas in 1825 numbered 443, a small amount when compared with other southern states (Curlee 1932:5). Though the Mexican government officially discouraged the owning of slaves in Texas, they took no overt actions to prevent the practice mostly because conventional wisdom saw slavery as a necessary institution, especially in a region as unsettled as Texas. Many settlers arriving in Texas had worked large farms and plantations in the South, which required large labor supplies. As a result, the majority of them brought slaves with them. An absence of adequate labor coupled with an abundance of cheap, unimproved land in Texas, further encouraged this trend. In order to develop the land, settlers argued that slavery was vital; without slaves, the vast agricultural resources of Texas would remain largely untapped. Such views dictated the economic activities in Texas in the antebellum period (Campbell 1989:50-51).

By the start of the Texas Revolution, settlers had firmly established the use of slave labor in developing farms. When colonists gathered in Washington-on-the-Brazos in March 1836 to create a constitution, slavery was one of the issues addressed. They ensured the survival of the institution in the new republic as Section 9 of the 1836 constitution demonstrates:

\begin{abstract}
All persons of color who were slaves for life previous to their emigration to Texas, and who are now held in bondage, shall remain in the like state of servitude....Congress shall pass no laws to prohibit emigrants from bringing their slaves into the republic with them, and holding them by the same tenure by which such slaves were held in the United States.... No free person of African descent, either in whole or in part, shall be permitted to reside permanently in the republic, without the consent of congress [Campbell 1989:46-47].
\end{abstract}

They also included in the constitution a ban on the African slave trade. By that time most people viewed slave trading as morally indefensible; nevertheless, illicit African slave trading continued on a limited basis until the 1840s. The majority of slaves in Texas, however, continued to arrive with their owners through migration from Southern states. Brazoria County planters already established in the county could make arrangements to purchase additional slaves through slave dealers, the largest of which operated in Houston and Galveston. The dealers arranged the purchase of slaves from Georgia, Virginia, and other slave states and then made them available to Texas planters (Campbell 1989:52-53).

The number of slaves in Brazoria County grew steadily after Texas independence until the end of the Civil War (Table 3-1). The United States annexation of Texas in 1846 caused

Table 3-1. Slave Population in Brazoria County, 1837-1864

Sources: Campbell (1989) and the Eighth Census, Agricultural Schedule, 1860.

\begin{tabular}{|c|c|c|c|c|c|c|c|c|}
\hline Year & 1837 & 1840 & 1845 & 1846 & 1850 & 1855 & 1860 & 1864 \\
\hline $\begin{array}{c}\text { Number of Slaves in } \\
\text { Brazoria County }\end{array}$ & 892 & 1,665 & 2,094 & 2,520 & 3,161 & 4,292 & 5,110 & 5,125 \\
\hline
\end{tabular}

\footnotetext{
${ }^{2}$ Brazoria County Federation of Women's Clubs, "History of Brazoria County," (1940), p. 41.
} 
a dramatic jump in the number of slaves, as settlers from the United States began arriving in Texas in larger numbers. Like many slave holding regions across the South, Brazoria County saw a disproportionate increase in slaves versus white citizens. While Brazoria County's white population grew during the antebellum period, the slave population grew at an even faster pace. In 1847 , the county's white population was 1,623 , while slaves numbered 3,013 , representing $65 \%$ of the population. By 1860 , that percentage was $71 \%$, with whites numbering 2,049 and blacks 5,110 (Few 1994:9).

The rapid growth of slavery in Brazoria County can be understood better when viewed in relation to slavery throughout the state. In the period that statistics for slavery exist, roughly 1837 to 1864 , Brazoria County ranked as one of the largest slave owning counties in Texas. Figures 3-1 and 3-2 illustrate this fact by showing the percentage of blacks in Brazoria County compared to the rest of the state's counties in 1840 and 1860.

As seen in Figures 3-1 and 3-2, Brazoria County was among several southeast counties with a high percentage of slaves. The large number of sugar and cotton plantations in the region explained the high concentration. In 1860, Brazoria County had the third highest number of slaves among Texas counties - only the counties of Washington and Rusk were higher. In addition, Brazoria County in 1860 included 10 of the 54 Texas slaveholders with 100 or more slaves. Of these ten, David G. Mills of Brazoria County was Texas' largest slaveholder with 344 slaves. $^{3}$

When compared to southern slaveholding states, Brazoria County exhibited unique characteristics regarding slavery. While the majority of southern states saw a decrease in the number of individuals owning slaves in the years leading up to the Civil War, Brazoria County slaveholders increased; in $1850,51 \%$ of the white population owned slaves, but in 1860 that number increased to $56 \%$. The value of slaves in Brazoria County was also higher than in other regions of the South as a result of the increased need for labor in Texas (Powers 1994:44).

Given that slavery had such an important role in the economic infrastructure of antebellum Texas, slave ownership often served as a mark of social status among planters in Brazoria County. Aside from land, slaves in large part represented the wealth of an individual. The number of slaves an individual owned determined his level of economic, political, and social success in antebellum Texas. Many of the top slaveholders in Brazoria County held powerful positions as bankers, lawyers, and state congressmen and were largely responsible for much of the wealth creation in the county. Though a minority, the wealthy planters of Brazoria County played a large part in determining the economic and political direction of the state before the Civil War (Wooster 1961:72).

\section{Agriculture and the Plantation Economy in Brazoria County, 1824-1861}

The explosive growth of both slavery and immigration were directly tied to the agricultural promise of Texas. Little else captured the attention of Texas' population after independence from Mexico and before the Civil War. Roughly $75 \%$ of Texas' white population was involved in agricultural pursuits in the antebellum period. From the initial settlement of Texas in the early 1820 s to 1861 , farmers throughout the state enjoyed a period of tremendous agricultural growth and diversity. The state benefited from a wealth of knowledge and became a "clearing house of Southern agriculture" (Curlee 1932:80).

The United States annexation of Texas in 1846 added to the agricultural vitality of the state. Settlers from the South moved to Texas in great numbers eager to buy cheap, fertile land and make their fortunes (Lowe and Campbell 1987:9). Popular magazines contributed to the excitement, as in this glowing 1851 passage from DeBow's Review:

No condition can be more independent and happy than that of the Texan farmer or planter. With a few weeks labor in the year, he can supply himself and family with all the necessaries and luxuries of life....No country in North America holds out such inducements to emigrants as Texas, both for the salubrity of its climate, the fertility of its soil, and the variety of its products. ${ }^{4}$

Settlers who established farms in the coastal counties of Brazoria, Fort Bend, Wharton, and Matagorda found fertile soil and a long growing season. In Brazoria County, settlers such as Josiah Bell, James Britton, John Sweeny, and John $\mathrm{McNeel}$ developed early farms and were engaged in cotton

\footnotetext{
${ }^{3} 1860$ Census, Texas State Library and Archives, Austin, Texas.

4 “Texas," DeBow's Review (June 1851), p. 642.
} 


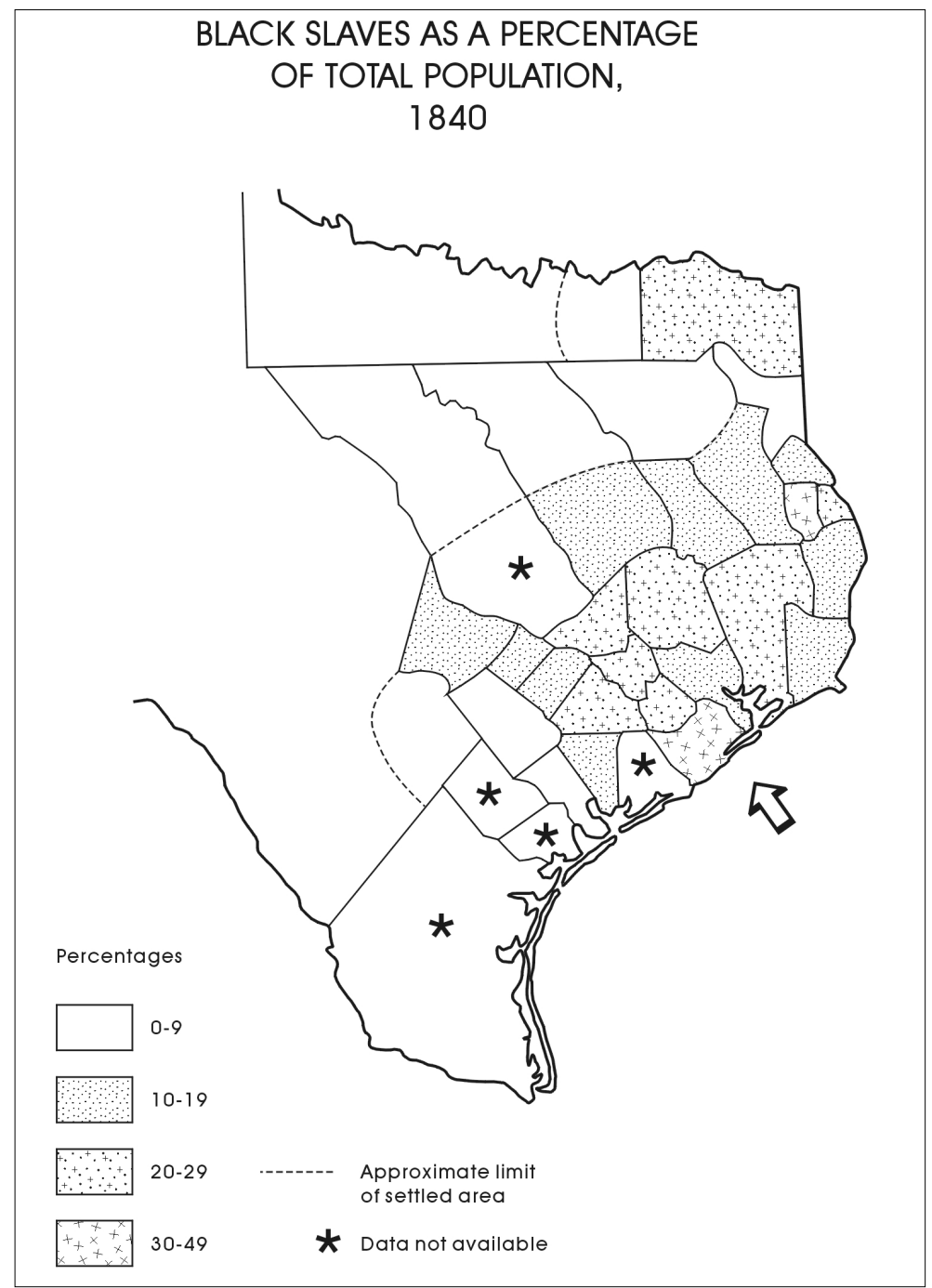

Figure 3-1. Black slaves as a percentage of total population, 1840. Source: Tuffly et al. (1976); redrafted.

growing. Because land was inexpensive in Brazoria County, farmers often had more acres of unimproved land than they had in cultivation. Some had ten times more acres of unimproved land (Curlee 1932:74). As a result, slavery remained the most important factor in the success of a planter; without slaves in the field, land remained uncultivated.

The development of a plantation economy in Brazoria County grew quickly as early settlers gathered enough land and slaves to commit to cash crops like cotton and sugar. Historians have defined a plantation as a farm utilizing at least 20 slaves. Planters who owned plantations either managed the agricultural duties themselves, used a slave foreman, or in the case of many large plantations, hired an overseer to run the operation. Farmers with limited funds, who raised a small amount of cotton and other crops in order to meet basic expenses and needs, owned farms with fewer than 20 slaves. The ratio of planters to farmers in Brazoria County was unlike the rest of the South. With the historians' definition of plantation, $30 \%$ of Brazoria County's slaveholders were plantation owners, a percentage that was much higher than the $12 \%$ characteristic of the South (Powers 1994:54).

Rising cotton prices, long growing seasons, and inexpensive land helped planters thrive, build more elaborate homes and experiment with new crops such as sugar cane. Between 1850 and 1860, planters in Brazoria County established 63 


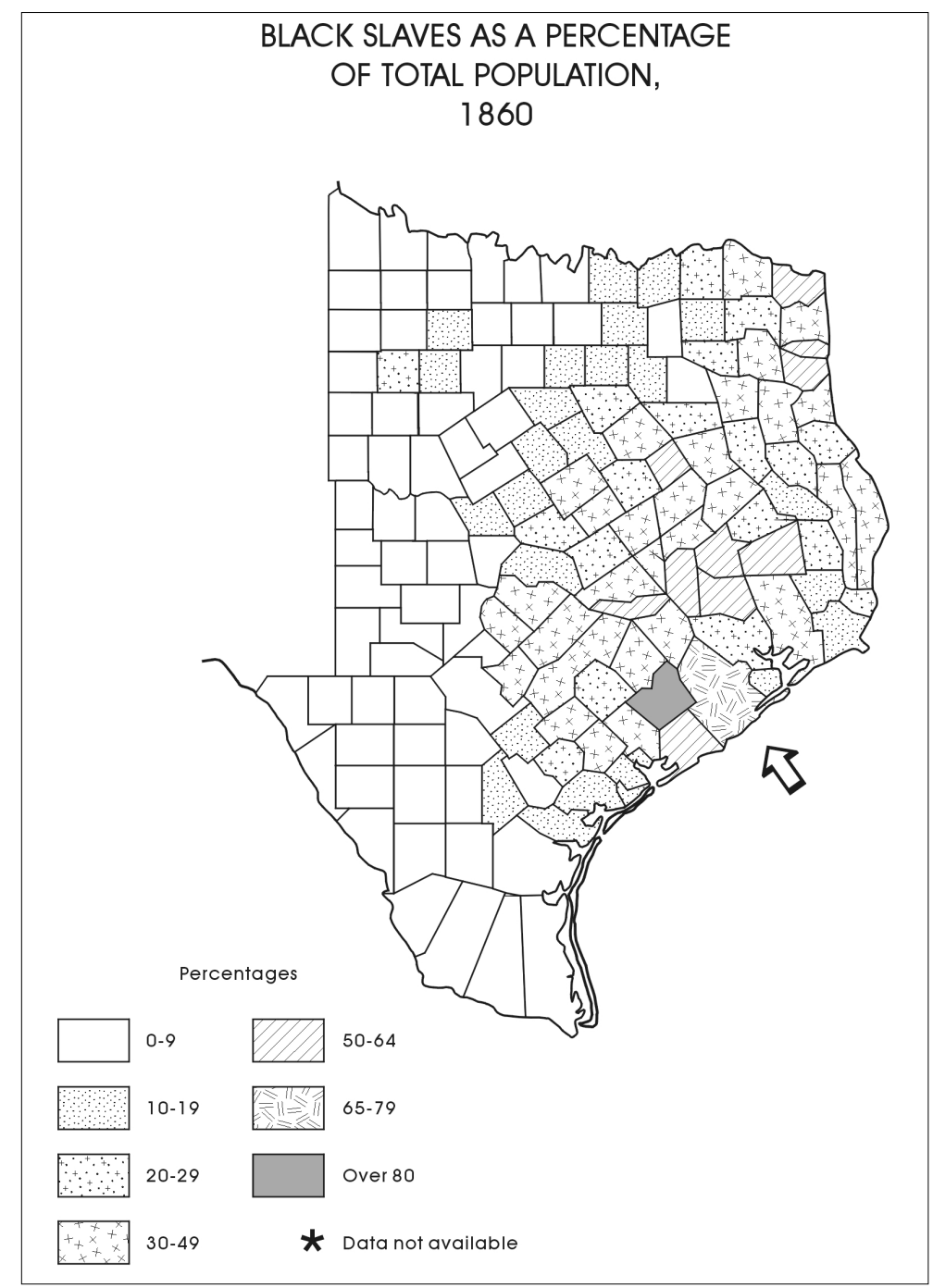

Figure 3-2. Black slaves as a percentage of total population, 1860. Source: Tuffly et al. (1976); redrafted.

plantations and emerged as one of the wealthiest counties in the state. ${ }^{5}$ The 1860 agricultural census attested to the success of Brazoria County plantations by listing more than 37,465 acres of land in cultivation. The county led all Texas counties in total cash value of farms and plantations $(\$ 4,815,603)$, as well as cash value of farming implements and machinery $(\$ 531,717)$. The plantation economy bestowed great social, political, and economic power on the planter class and defined life in the county for decades.

\section{Cotton Farming in Brazoria County}

From the early settlement of Brazoria County to the Civil War, cotton played a major role in the rapid evolution of a plantation economy in the region. In Brazoria County, as in much of the antebellum South, the cultivation of cotton brought great wealth to planters with enough land and slaves for production. By the beginning of the Civil War, Texas had become the fifth largest cotton-producing state in the country. Table 3-2 illustrates the rapid rise of cotton production in antebellum Texas.

The origins of cotton production in Brazoria County began during the initial organization of Moses and Stephen F. Austin's colony of settlers in the early 1820s. Both men knew the potential that cotton held for the region's future. Stephen F. Austin actively recruited settlers eager to grow

${ }^{5}$ The figure of 63 plantations was arrived at by calculating the number of slaveholders with 20 or more slaves. 
Table 3-2. Cotton Crops in Texas, 1830-1860 Source: Texas Department of Agriculture (1909).

\begin{tabular}{|c|c|}
\hline Year & Total Cotton Crops in Bales \\
\hline $1830-1831$ & 335 \\
\hline $1834-1835$ & 3,084 \\
\hline $1839-1840$ & 6,970 \\
\hline $1844-1845$ & 25,879 \\
\hline $1849-1850$ & 58,072 \\
\hline $1854-1855$ & 125,427 \\
\hline $1859-1860$ & 431,463 \\
\hline
\end{tabular}

cotton and even claimed he would accept bales as payment for land. By 1822, early settlers in Brazoria County had planted the first cotton seeds in the region. The hot climate and rich soil of the county proved ideal for the growth of cotton and soon it emerged as the county's primary cash crop (White 1957:256). Statistics demonstrate that the county was among the top producers of cotton until the Civil War, with 3,531 bales produced in 1850 and 12,215 bales in 1860 . Only six counties in Texas produced more cotton than Brazoria County in 1860 (Powers 1994:67).

The process of planting cotton in the county, like much of antebellum agriculture, was labor intensive. Planting began in late February in the warmer coastal climates like Brazoria County. Plows prepared fields for cultivation, and cottonseed from the previous year was planted. After a couple of weeks, the cotton seedlings would emerge and slaves would begin keeping seedlings free from weeds, a process that continued through the summer. The cotton plants began blooming in June and by August were ready for picking (Powers 1994:66-67). Planters faced multiple threats to their cotton crops ranging from inclement weather to pests and diseases. The lack of rain resulted in rust, but too much rain caused crops to rot. At varying stages of growth, the cut-worm, caterpillar, and army worm threatened cotton, and 1840$43,1846,1847$, and 1849 all saw damage from pests and disease (Curlee 1932:159-160).

Planters that avoided severe damage to their crops began the process of cotton picking in August. The average slave picked 150 to 200 pounds a day and worked dawn to dusk six or seven days a week. By the end of the year, most fields had been picked clean, although during some of the more productive years, cotton picking continued into January and February.

After picking came ginning, a process that cleaned and seeded cotton and then pressed it for export to larger markets.
Ever since the invention of the cotton gin in the late eighteenth century, cotton production had drastically increased. Cotton farmers arriving in Texas from the South in the 1820 s were eager to establish cotton gins alongside their cotton fields. Planter Jared E. Groce built the first gin in Austin's colony in 1825. Three years later, John McNeel, a cotton farmer from Kentucky, built one of the first cotton gins in Brazoria County. Noah Smithwick, a blacksmith, used steel from a shipwreck off the coast to construct the machine (White 1957:432-433).

By the 1840s, most of the larger planters owned cotton gins. For a fee, smaller cotton farmers often used the gins of larger planters to gin their cotton. Construction costs for the gins averaged $\$ 150$ and were either built by blacksmiths in the area or by gin manufacturing companies, such as those owned by Daniel Pratt, Robert Matthew, Manning and Arnett, and William Shield. Planters also used cotton presses, which pressed the ginned cotton into 400 or 450 pound bales. Gin houses usually housed cotton gins and presses and were located at least a half mile from any dwelling, fireplace, or chimney due to the danger of fire (Curlee 1932:167). Figure 3-3 shows a typical Brazoria County gin house from the 1850s.

From start to finish, a single slave averaged about ten bales of cotton and an acre of land in Brazoria County yielded 2,000 to 4,000 pounds of seed cotton. After ginning, cleaning and pressing, cotton bales were then ready to be transported to cotton markets. For most planters in Brazoria County, the Brazos River provided a convenient and efficient mode of transportation for their cotton. Using rafts or steamboats, planters shipped the cotton bales to Galveston, where commission merchants or "factors" purchased the shipments. Merchants then stored the cotton and eventually sold it at a good price to cotton buyers. Profits, minus fees and commission, were then sent by the merchants to the planters in Brazoria County. Despite unfortunate years of drought, floods, pests, and disease, cotton production was lucrative for many planters and created much of the success of antebellum plantations in Brazoria County. With slavery providing free labor, planters reaped enormous profits from the production of cotton. As historian Abigail Curlee wrote, cotton:

administered to his [planter] love of power, paid his taxes; bought his coffee, sugar, and silver plate; clothed his family in substantial dignity and covered his slaves anew twice a year; and in fortunate years left him substantial balance with his factor in New Orleans, New York, or Galveston [Curlee 1932:174]. 


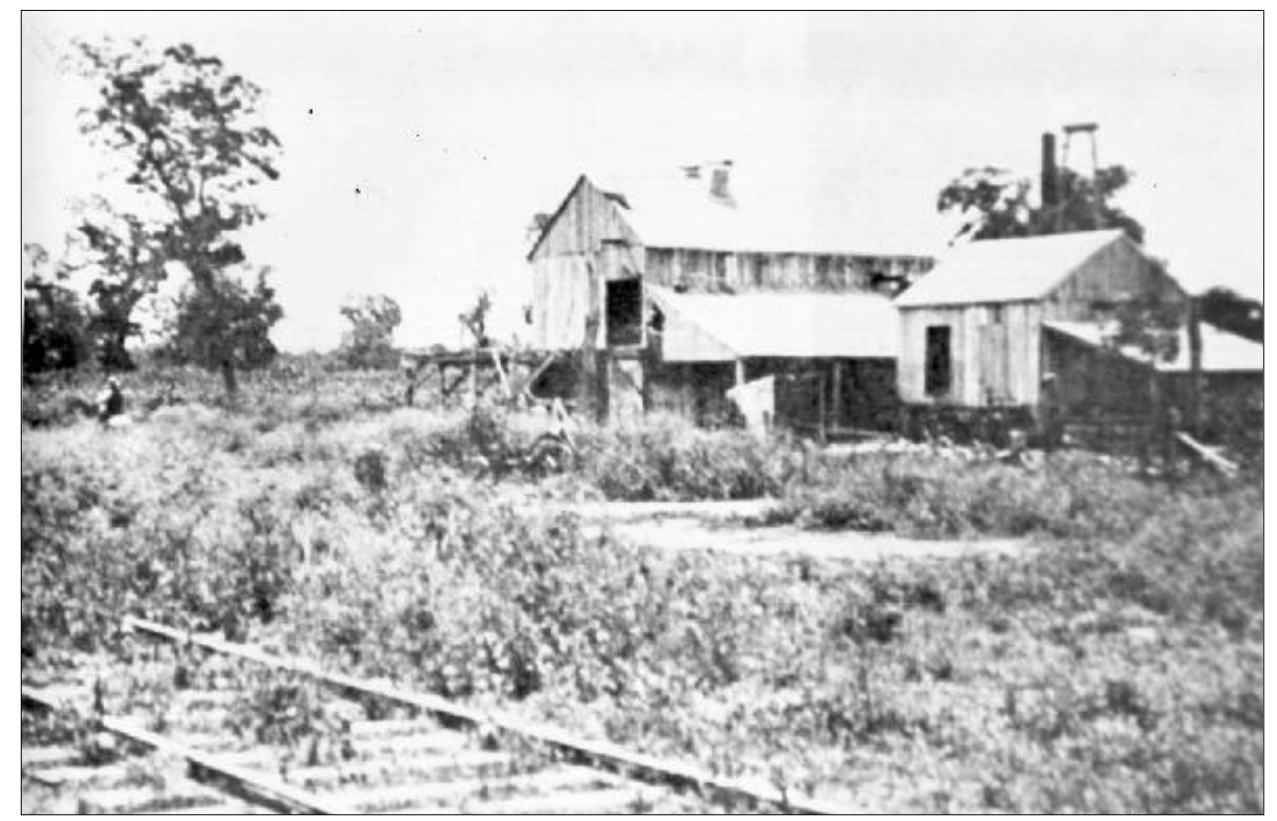

Figure 3-3. Cotton gin on the Sweeny Plantation, Brazoria County, Texas, ca. 1870. Notice the close proximity of the cotton gin to the railroad.

Source: Brazoria County Historical Museum.

\section{Sugar Cane in Brazoria County}

While cotton was considered the major cash crop in Brazoria County and the rest of Texas, sugar cane eventually became synonymous with the growing plantations in Brazoria County. Though never threatening the vast markets of sugar grown in Louisiana, sugar cane cultivation in Texas established itself as an important component of economic life in the coastal region, especially in Brazoria County. By 1850 , the four coastal counties of Brazoria, Fort Bend, Wharton, and Matagorda became known as the Texas Sugar Bowl because of the large amounts of sugar produced there.

Prior to sugar cane's introduction in Texas, the first appearance of the crop in America occurred in the mideighteenth century in Louisiana. In 1823, sugar planters there produced 30,000 hogsheads (a wooden container holding 63 to 140 gallons) of sugar a year. The success of sugar cultivation in Louisiana most likely convinced settlers heading to Texas of the crop's potential in the new region (Johnson 1961:9). In fact, both Moses and Stephen F. Austin thought that along with cotton, sugar cultivation could be successful in Texas. In fact, many colonists attempted to grow sugar. Visiting Texas in 1828, J. C. Clopper mentioned the early colonist attempts at sugar cultivation: ...there is more than one individual on this Mississippi of Texas, as the Brazos may be termed if small things may be compared with great, who will turn out more than 100 bales of cotton and sugar cane proportionally - it is thought there will be a sufficiency of sugar made this year to supply both Colonies-Austin's and Dewitt's...There are several planters already engaged in erecting sugar mills and they have resolved to dispose of it at 10 cts this is cheaper than it can be sold at here by purchasers and shippers from N. Orleans [Curlee 1932:174-175].

Also in 1828, Stephen F. Austin favorably reported the introduction of sugar in Texas: “... about six hundred bales of cotton and eighty hogsheads of sugar will be made this season" (Johnson 1961:11). As J. C. Clopper notes, colonists had begun erecting sugar mills in 1828 . William Stafford, an early colonist, built the first sugar mill in the colony in 1834, but it was destroyed by the Mexican Army two years later. Stafford's early attempts at sugar production created a product that "was little more than partially crystallized molasses." Successive attempts and better cultivation techniques gradually resulted in a better product (Curlee 1932:176). 
One of the earliest planters of sugar cane in Brazoria County was John Sweeny, who arrived in Texas in 1832 with his family and a large contingent of slaves. Settling on the San Bernard River, Sweeny developed a large sugar plantation with the help of his sons and slaves. The Sweeny sugar mill used wooden rollers made out of native live oak trees. By 1844, Sweeny produced 100 hogsheads of superior sugar and over 100 barrels of molasses. One newspaper classified Sweeny's 1844 crop as comparable to and less expensive than Louisiana sugar (Johnson 1961:15). Further newspaper accounts described his success at raising seven successive sugar crops from the same roots, with no loss in quality. The ability of sugar cane to repeatedly propagate from an original cane source was called "rattooning." Brazoria County planters often explained that the Texas variety of cane rattooned at least six times, whereas Louisiana planters often had to replant each year (Curlee 1932:181-183).

Other early sugar planters in Brazoria County included Eli Mercer, Henry W. Munson and James P. Caldwell, all of whom established large sugar plantations along the Colorado and Brazos rivers. The emerging concentration of sugar planters in the coastal region, including Brazoria County, was due in large part to the area's extended growing season, a factor that allowed sugar cane enough time to mature for sugar production. These early planters experimented with two types of sugar cane: creole and ribbon cane. Heavily used by Louisiana planters, creole cane was the predominant type used; however, as early as 1828 , Texas planters learned from China about ribbon cane, which matured a month faster than other varieties. It was not until the introduction of steam power sugar mills, however, that planters began using ribbon cane, because the cane's tough fibers required grinding wheels to have stronger crushing power (Creighton 1986:197).

By the early 1840 s, several unrelated factors spurred the spread of sugar cultivation among planters in the county. Prior to this, cotton was the crop of choice for Texas farmers, especially given its easy cultivation and high profit margin. However, in 1840, a disastrous cotton worm infestation destroyed half of the region's cotton crops. A flood of rain in 1842 and 1843 further decimated cotton crops leaving many planters in the county worried about the reliability of cotton. To make conditions worse, prices for cotton were falling, planters faced cotton tariffs, and the panic of 1837 had destabilized Texas' paper currency. An article in the Brazos Courier in 1840 suggested a turn to sugar cultivation to offset the disappointments of cotton:
The few attempts [at sugar cultivation] which have been made in Texas have served to show that when the attempt is rightly made it will be crowned with signal success; and we doubt not that this, in a few years, will be found a very important item in the productions of this country. We desire earnestly to see a beginning made, and feel satisfied that the farmer will find this, at least as profitable a business as cotton planting, and much less mixt with uncertainties [Johnson 1961:13].

Recognizing these potential benefits of sugar cultivation, more and more planters made the shift to sugar. Others simply supplemented their cotton income with sugar production. In a few short years, sugar production in Brazoria County grew as a result of additional planters and an increased emphasis on the crop. One area in the coastal region saw a $23 \%$ increase in production in one year in the early 1840s (Curlee 1932:178).

Concurrent with the shift towards sugar cultivation were advances in sugar mill technology, which greatly improved production in the region. In fact, the evolution of sugar mills in Brazoria County paralleled the explosive growth of sugar in the region. In 1843, Captain William Duncan, who owned a plantation on Caney Creek, established the first steam powered sugar mill in Texas. The increased power from steam allowed Duncan to extract more cane juice more quickly than previous mills. Prior to steam, mills were powered by horses and used wooden rollers to crush the sugar cane.

The introduction of steam powered mills accelerated planters' investment in sugar. To house the new steam mills, planters built sugar houses of wood, and in some cases, brick. Sugar mills were often two stories in height and included space for the engine, the grinding rollers, juice vats as well as cooling areas for the final product. Waldeck Plantation in Brazoria County was one of the finest examples of sugar mills in the state and resembled a turreted castle with its three stacks (see Figure 3-4). Construction of the Waldeck mill exceeded $\$ 50,000$ and included the most current sugar refining technology in 1849 (Creighton 1986:199-200). Figure 3-5 shows drawings of a slave-constructed sugar mill from the 1840s in Brazoria County.

Planter investments in infrastructure at this time made clear the high overhead costs required of planters interested in entering the sugar business. As a result, after 1843, planters 


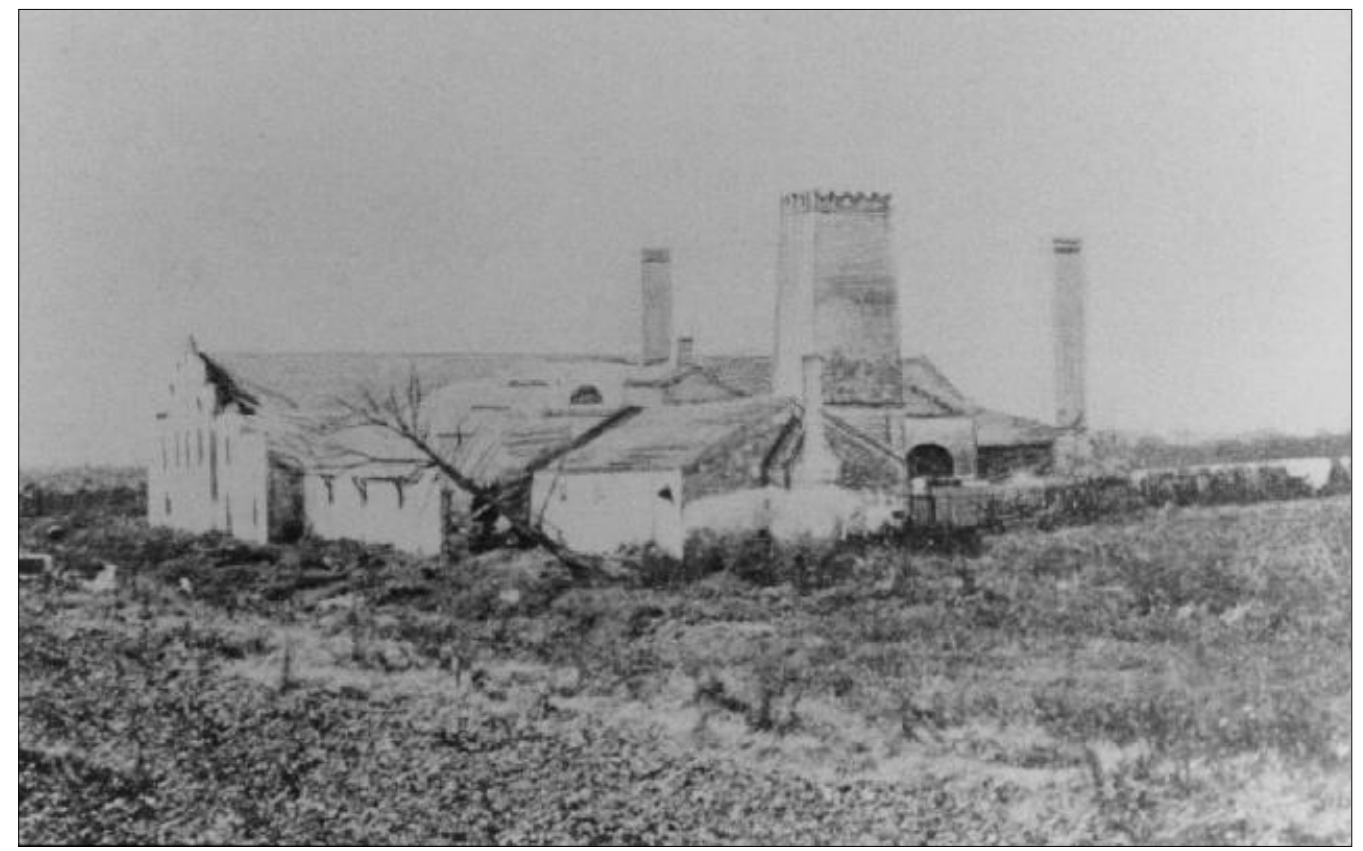

Figure 3-4. Waldeck sugar mill at Waldeck Plantation, Brazoria County, Texas. Source: Brazoria County Historical Museum.

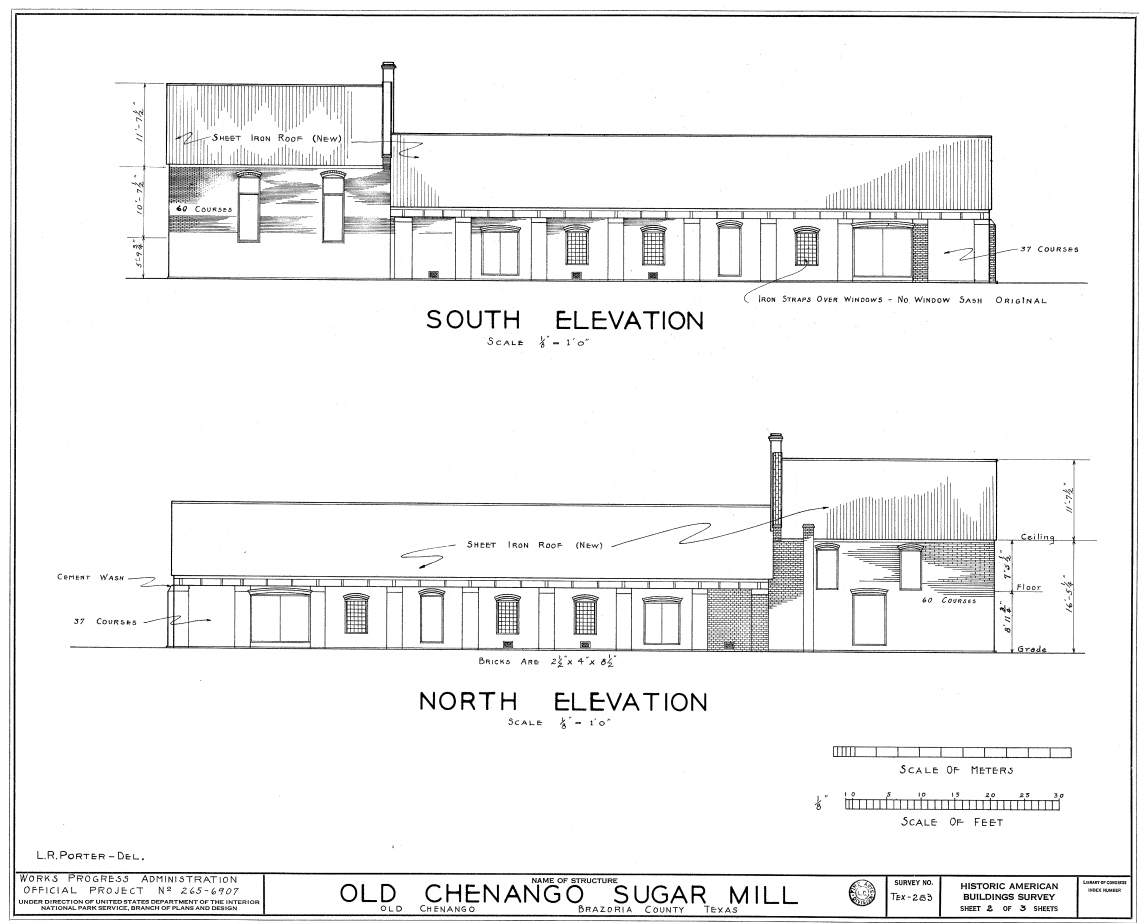

Figure 3-5. Chenango Sugar Mill, Brazoria County, Texas. Source: Library of Congress. 
growing sugar were almost entirely wealthy men. New sugar houses ranged in cost from $\$ 5,000$ to $\$ 50,000$, with an average cost of $\$ 15,000$. In 1843 , the annual cost for a sugar planter was $\$ 50,000$ including 50 slaves and associated buildings. Agricultural censuses taken in 1850 and 1860 show Brazoria County planters making large investments in machinery - in most cases, the machinery was related to sugar production (Lowe and Campbell 1987:20).

In addition to the high costs of machinery, sugar cultivation required large numbers of slaves. Planting and processing sugar was a long and involved process, which began in January or February when slaves plowed fields into furrows. Slaves planted cane from the previous year's crop in the furrows and covered it with soil. When warm weather arrived, they removed a layer of soil to encourage the growth of the cane. As in cotton production, slaves periodically kept the crops free from weeds until the plants reached a mature height in late June. Slaves returned in October to cut the cane stalks, remove leaves and branches, and place the harvested cane on wagons on their way to the sugar house. The work of cutting cane in the fields was very difficult, and lasted from sunup to sundown, seven days a week (Lowe and Campbell 1987:20-21).

Once the cut cane reached the sugar house, slaves at the sugar mill worked an equally demanding schedule; planters required slaves to work round-the-clock shifts during processing months. The processing began with the placement of the cane into the steam-powered grinding rollers of the mill. With 150 pounds of steam pressure, the rollers crushed the cane until juices flowed into a large clarification vat made of copper or lead. Clarification removed impurities before the juice was moved to open kettles where further clarification and evaporation took place. The kettles, usually wrought iron, numbered four to six and were used to pass the cane juice through successive levels of processing. As seen in Figure 3-6, French terms identified the kettles. As the cane juice moved from kettle to kettle, the volume of juice decreased and became purer. A furnace heated each kettle and removed additional impurities from the cane juice. As the concentrated juice reached the last kettle, it cooked until it was ready for the cooling process (Johnson 1961:24-25).

The sugar cane juice was then poured into cooling troughs, where after six to fourteen hours, it formed sugar crystals. Slaves placed granulated sugar in hogsheads and allowed it to drain for 20 to 30 days; the molasses that drained from the hogsheads was collected and then sold along with the unrefined sugar. The hogsheads of sugar were shipped to Houston or Galveston via steamship or railroad and then sold to buyers. A tremendous amount of effort was needed to produce one hogshead of sugar and two barrels of molasses; one estimate claimed that 1,300 pounds of raw sugar cane were needed to produce such an amount (Creighton 1986:201).

Because of the gradual shift to sugar and the adoption of steam-powered mills, the sugar output for Brazoria climbed in 1846, 1847, and 1848. In 1849, the Sugar Bowl region of Texas produced 7,351 hogsheads of sugar, a phenomenal number considering the relatively short period that sugar had been in Texas. Brazoria County stood alone as the highest producer of sugar that year, with 4,811 hogsheads. Production in 1850 and 1851 decreased somewhat due to a severe drought in 1850 . However, in 1852, Brazoria County and the rest of the sugar-growing counties of Texas produced the highest output of sugar before the start of the Civil War. A total of 11,023 hogsheads was produced, and Brazoria County led all counties once again with 8,202 hogsheads.

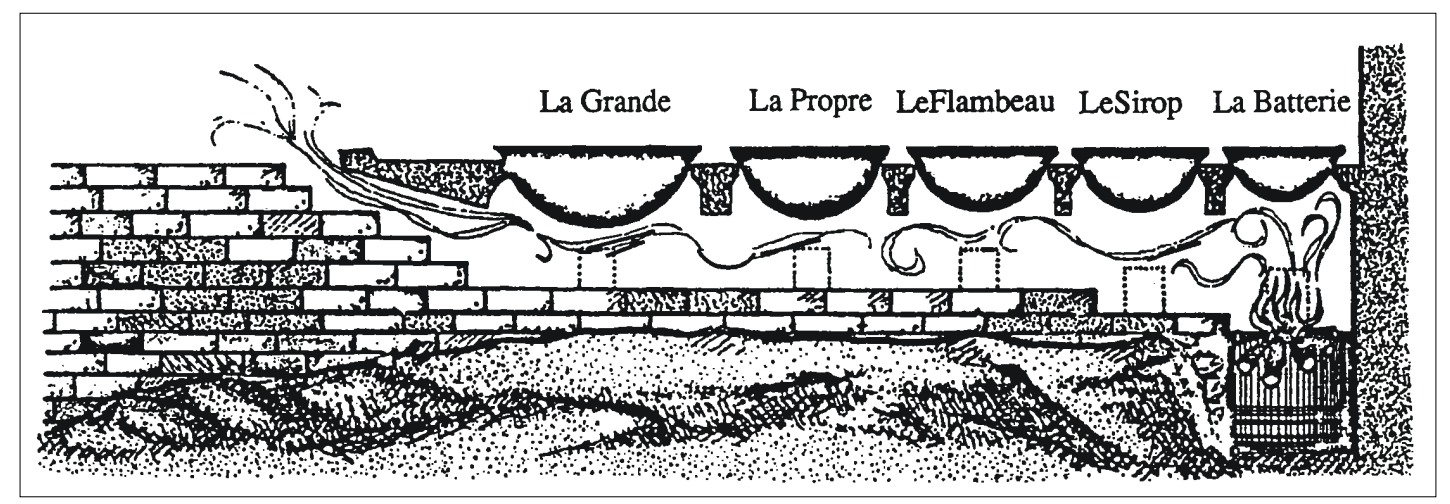

Figure 3-6. Detail of sugar mill kettle system. Source: Few (1994). 
The crop that year was so successful that Louisiana listed it for the first time in their annual account of sugar production. Twenty-nine planters in Brazoria County were listed as having produced sugar that year - a sizeable increase from previous years. The county's investment in sugar production that year totaled $\$ 1,134,000$ in sugar houses, slaves, and land, a sum demonstrating the enormous wealth of planters in the region. Texas' output of sugar, however, never equaled Louisiana. In 1852, Louisiana produced 321,934 hogsheads compared to Texas' 11,023. Nonetheless, Brazoria County planters reaped enormous profit from the 1852 crops. Table 3-3 lists some of the top sugar producers in Brazoria County for 1852 .

Though sugar production in Texas never exceeded the 11,023 hogsheads of sugar from 1852, the next three years produced respectable yields. A cold winter in 1856, however, proved that sugar was just as vulnerable as cotton to the extremes of Texas weather. Production for that year totaled 150 hogsheads, down from 8,977 the previous year. As a result, the trend of planters moving from cotton to sugar slowed considerably. Because machinery for sugar cultivation was so expensive, and lands suitable for production limited, the number of sugar planters decreased after 1856. A Galveston commercial publication that year reached the same conclusions of many planters in the region when it claimed that "the present year closes an epoch in the growth of sugar in Texas." Subsequent years saw a larger increase in production, but still considerably lower than 1852. The beginning of the Civil War in 1861 interrupted production and signaled the end of plantation driven sugar production in Brazoria County. Though the industry resurfaced after the war, it bore little resemblance to the highly prosperous plantation system in the antebellum period (Curlee 1932:191-197).

\section{Corn Production in Brazoria County}

Though cotton and sugar provided Brazoria County planters with pure profit, the production of corn sustained plantation life throughout the state. Requiring little expense or labor to grow, corn provided a consistent supply of food for planters and slaves, as well as cattle, horses, mules and other plantation animals. An 1853 article in DeBow's Review stated that corn production in Texas was an important agricultural advantage for planters:

The land here is unrivaled in the production of corn by any southern soil-from forty to sixty bushels to the acre being an ordinary yield - enabling the planter, with little trouble, to supply himself with this indispensable article at no cost. ${ }^{6}$

Table 3-3. Production of Sugar in Brazoria County, Texas, 1852

Source: Champomier (1852/53).

\begin{tabular}{|l|c|}
\hline Planter (Brazoria Countv) & Number of Hogsheads \\
\hline R. \& D.G. Mills (Bynum Place) & 558 \\
\hline Charles D. Sayre & 200 \\
\hline William Manor & 200 \\
\hline Col. Morgan L. Smith & 520 \\
\hline C.R. Patton & 210 \\
\hline R \& D.G. Mills (Lowood Place) & 780 \\
\hline James P. Caldwell & 200 \\
\hline A.F. Westall & 285 \\
\hline James Perry & 260 \\
\hline James G. McNeel & 408 \\
\hline Sarah Mims & 368 \\
\hline Gen. James Hamilton & 450 \\
\hline Maj. A. Jackson & 296 \\
\hline Col. W. Sharp & 500 \\
\hline Hal. G. Runnels & 270 \\
\hline
\end{tabular}

6 “Texas-Climate, Rivers, Lands, Productions, Animals, Minerals, Population, Government, Emigration,” Debow's Review 1853, (Vol. III), p. 642. 
Planters valued corn production as necessary protection against the uncertainties that could decimate cash crops like cotton or sugar. Thus, planters almost always created space in their fields for corn production. Yields in Brazoria County averaged 40 to 80 bushels, which planters stored in corn cribs and saved for livestock feed or ground into cornmeal for corn bread and hominy. They used several methods to grind corn, including horse or hand mills, with grist mills appearing in the county after the late $1820 \mathrm{~s}$. The amount of corn grown in Texas from 1829 to 1860 demonstrates the value corn held in the plantation economy (see Table 3-4). Statistics for Brazoria County's corn production were only available for 1860 , when the yield was 299,820 bushels (Curlee 1932:201-202).

Table 3-4. Cotton production in Texas Source: Curlee (1932).

\begin{tabular}{|c|c|}
\hline Year & Bushels of Corn \\
\hline 1829 & 150,000 \\
\hline 1850 & $5,978,590$ \\
\hline 1860 & $16,500,702$ \\
\hline
\end{tabular}

\section{Other Crops and Livestock in Brazoria County} Brazoria County plantations supplemented their diets with a variety of vegetables and livestock. Aside from corn, planters grew a steady supply of sweet potatoes, Irish potatoes, and peas. One of the larger plantation owners, David G. Mills, raised a total of 25,000 bushels of corn, 9,000 bushels of sweet potatoes, and 250 bushels of field peas in 1850 in order to feed his large slave force. Some planters grew elaborate fruit orchards often with seeds brought from southern states. $^{7}$

Livestock represented an important part of the plantation system by providing necessary sustenance for slaves and families alike. Hogs roamed wild until a few weeks before slaughtering time, when they grew fat on corn. Planters preserved meat for use throughout the year and rationed it out to slaves as part of their daily meals. Cattle also provided necessary meat for planters in Brazoria County. In the years leading up to the Civil War, stock raising became an increasingly important activity for many planters. In 1860, Brazoria County included 66,000 cattle, making it one of the top ten cattle producers in the state; the total cash value was nearly $\$ 1,000,000$. One Brazoria cotton planter, Mordello S. Munson, owned 86 cattle in 1850 . Ten years later, he had increased that to $300 .{ }^{8}$ The Munson family continued to raise cattle after the Civil War and represented some the wealthiest cattle ranchers in postbellum Brazoria County. The early success of stock raising in the county thus signaled the rise of the cattle industry, which after the Civil War emerged as a more integral component of the county's agriculture (Powers 1994:79).

\section{Brazoria County Plantations}

By 1860 , Brazoria County was home to 63 plantations (given the definition of 20 slaves or more) some of which grew cotton or sugar exclusively, while many cultivated both. Since Brazoria County plantation owners were among the wealthiest individuals in the state, they owned some of the grandest plantations in Texas. The majority arrived in Texas from the old southern plantation states, bringing with them "inherited attitudes, customs, and methods" (Curlee 1932:iv). As a result, plantations in the county incorporated many traditional southern elements. Nevertheless, the unique characteristics of life in Texas, such as limited transportation, high soil fertility, and a long growing season, shaped the development of plantations in the state.

To better understand the characteristics of plantations in Brazoria County, three plantations-Bynum Place, Willow Glen, and Ridgeley Plantation — will be examined.

\section{Bynum Place}

Located in what is today known as Bailey's Prairie, Bynum Place was owned by David G. and Robert Mills, two brothers who played an important social and economic role in Brazoria County. Moving from Tennessee to Texas in 1832, the Mills brothers joined their brother Andrew in a merchandising business. After Texas gained independence, the Mills brothers quickly became important in the young economy of the republic. In 1849, their merchandising firm moved to Galveston, where it became one of the leading exporters of Texas cotton and sugar. Both quickly became wealthy and were worth between $\$ 3$ and $\$ 5$ million by 1860 . While Robert ran the firm in Galveston, David operated three plantations in Brazoria County - Low Wood, Palo Alto, and Bynum Place. By 1860, David Mills oversaw 200,000 acres of Texas land, with 3,300 in cultivation. In 1844, the three plantations produced 600 bales of cotton, the highest in the state at that time. Sugar production on the Mills' plantations also exceeded all others in 1852 (Harris 2003).

\footnotetext{
${ }^{7} 1850$ Agricultural Census, Texas State Library and Archives, Austin, Texas.

${ }^{8}$ 1850, 1860 Agricultural Census, Texas State Library and Archives, Austin, Texas.
} 
According to the 1850 and 1860 agricultural census for Texas, Bynum Place had 850 acres in cultivation and 3,200 acres of uncultivated land. In 1850, Bynum Place contributed 656 hogsheads of sugar, its highest output in the antebellum period. ${ }^{9}$ In addition to sugar, the plantation grew corn, Irish potatoes, and sweet potatoes. Livestock included hogs, horses, cattle, mules, oxen, and milk cows. Farming implements and machinery in 1850 were valued at $\$ 15,000$, which included a brick sugar mill on the plantation grounds. In addition to the mill, outbuildings were constructed of bricks made by slaves (Strobel 1930:10).

David Mills depended upon a large slave force to operate his plantations. In 1850, the three plantations included a total of 344 slaves. By 1860, Bynum Place alone used 120 slaves housed in thirty slave cabins. Among Brazoria County's plantations, the Mills brothers operations were among the largest and wealthiest. ${ }^{10}$

\section{Willow Glen Plantation}

The land associated with Willow Glen Plantation was originally part of James Brit Bailey's league. In 1832, Bailey sold a half league of land to Charles D. Sayre, a trader from New York who came to Texas in 1831. In 1835, Sayre built a cotton gin, processing 100 bales of cotton that year. During the period of Texas independence, Sayre was actively involved, serving in the militia, as well as supporting the movement financially. In 1840, Sayre owned 24 slaves most of whom were actively involved in processing sugar cane (Roell 2003). Like many Brazoria County planters at the time, Sayre moved from cotton to sugar cultivation due to its profitability and suitability to the region. Sayre erected a sugar mill located on the nearby Josiah Bell plantation in East Columbia. James Henry Dance, who built numerous mills across the county, built the mill (Creighton 1986:199).

In addition to the sugar mill, Sayre and his wife constructed a two-story frame residence, slave cabins, a smokehouse, barns, stables, and other outbuildings. A public road marked the plantation's southern border. The 1850 agricultural census shows Sayre with 300 acres in cultivation and the cash value of the farm totaling $\$ 9,000$. The value of Sayre's farming implements was $\$ 20,000$, demonstrating that he had invested heavily in the equipment need for sugar production. ${ }^{11}$ Sayre was one of the top twenty producers of sugar in the county. In 1850 , he produced 160 hogsheads of sugar; by 1852 , that number had increased to 200 hogsheads. Sayre died in 1856, and the plantation was sold to James Campbell who continued to grow sugar. Figure 3-7 shows a 1914 plat map of the Willow Glen plantation, which by that time retained little if any of its original physical features.

\section{Ridgeley Plantation}

In 1850, Mordello S. Munson and his new wife settled on 1,000 acres of land he received from his mother and stepfather and established Ridgeley Plantation. Deed records described the tract as "containing 1,000 acres being the west end of the tract of 2,479 acres situated on the east bank of the Brazos River in the county and purchased from the said William J. Bryan." The land was located in the western portion of the Cornelius Smith league (Williamson 1987:307).

Upon arrival in 1850, M. S. Munson and his wife, Sarah, lived in a small house known as "Hard Castle." Later that year, Munson began to expand his farmstead by purchasing 300 adjoining acres to the west. Additional land purchases increased Munson's plantation to 1,500 acres by 1859 . Owning eight slaves in 1850, Munson began planting cotton, corn, and vegetables, and raising livestock. Munson operated his land as a cotton plantation, and sold the product to brokers in Columbia and Brazoria.

The 1850 agricultural census listed Munson with 110 acres in cultivation and $\$ 600$ dollars worth of farming implements (cotton press, cotton gin, etc.). Munson produced 19 bales (400 lb. each) of ginned cotton and raised 200 swine and 86 livestock. The cash value of Munson's farm was $\$ 2,200$, with livestock adding another $\$ 1,512 .{ }^{12}$

In 1855, Munson and his wife built a new home a short distance from their first house. Four bedrooms in size, the plantation house, named Ridgeley, included a living room, dining room, and a long porch in the front (Figures 3-8 and $3-9)$. In addition to the main residence, there was a separate kitchen approximately 20 feet from the house, an office, a blacksmith shop, smokehouse, barns, stables, and slave quarters. All buildings at Ridgeley Plantation were made of wood, while cisterns, chimneys, and walkways were constructed of bricks manufactured by the slaves. ${ }^{13}$

${ }^{9} 1850$ Census, Texas State Library and Archives, Austin, Texas.

${ }^{10}$ 1850, 1860 Slave Schedule, Texas State Library and Archives, Austin, Texas.

${ }^{11} 1850$ Agricultural Census, Texas State Library and Archives, Austin, Texas.

121850 Agricultural Census, Texas State Library and Archives, Austin, Texas.

13 "Plantations," Vertical Files, Brazoria County Historical Museum. 


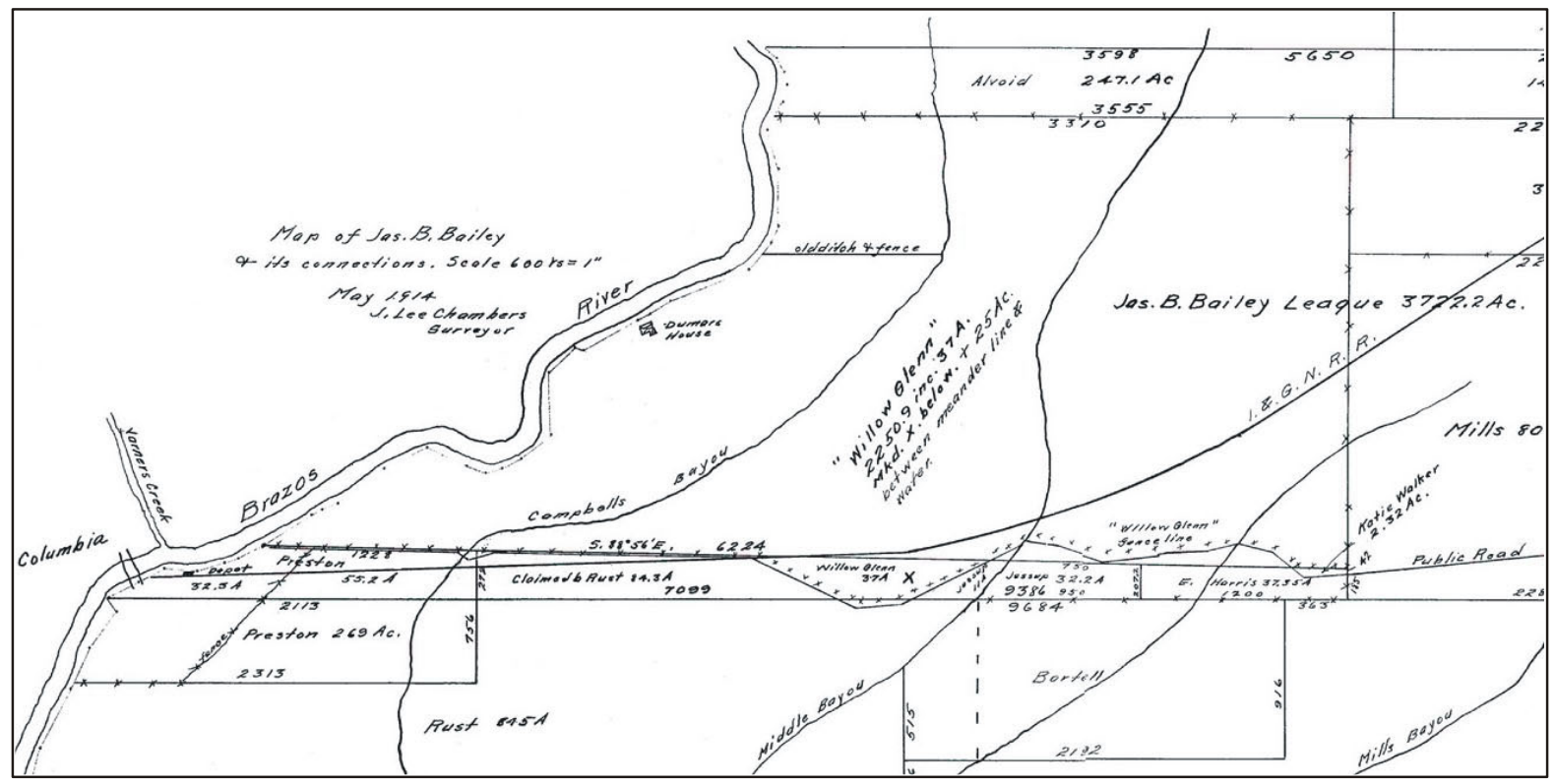

Figure 3-7. 1914 plat map showing the location of Willow Glen Plantation. Source: Brazoria County Historical Museum.

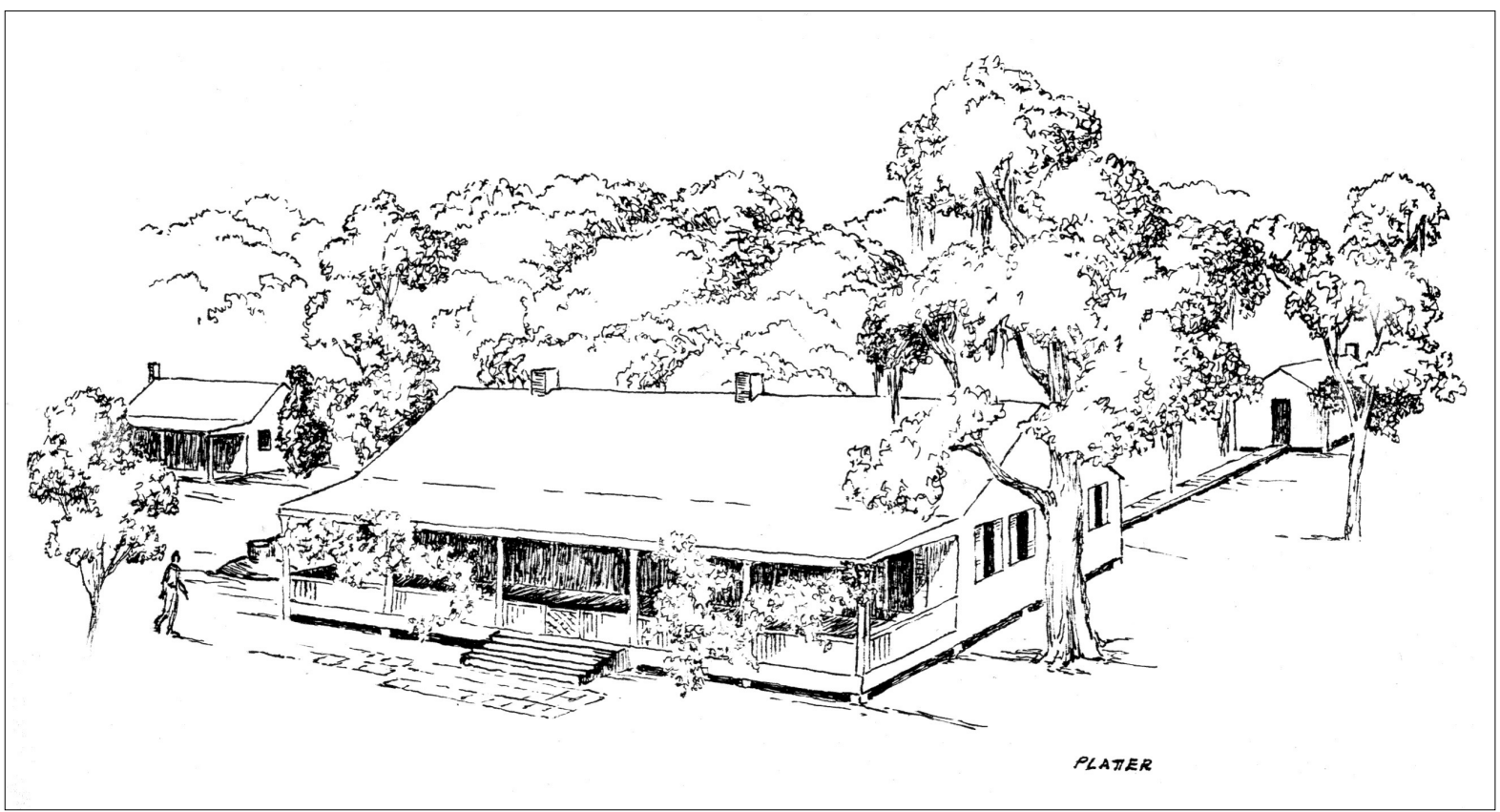

Figure 3-8. Drawing of the main residence at Ridgeley Plantation. Source: Platter (1961). 


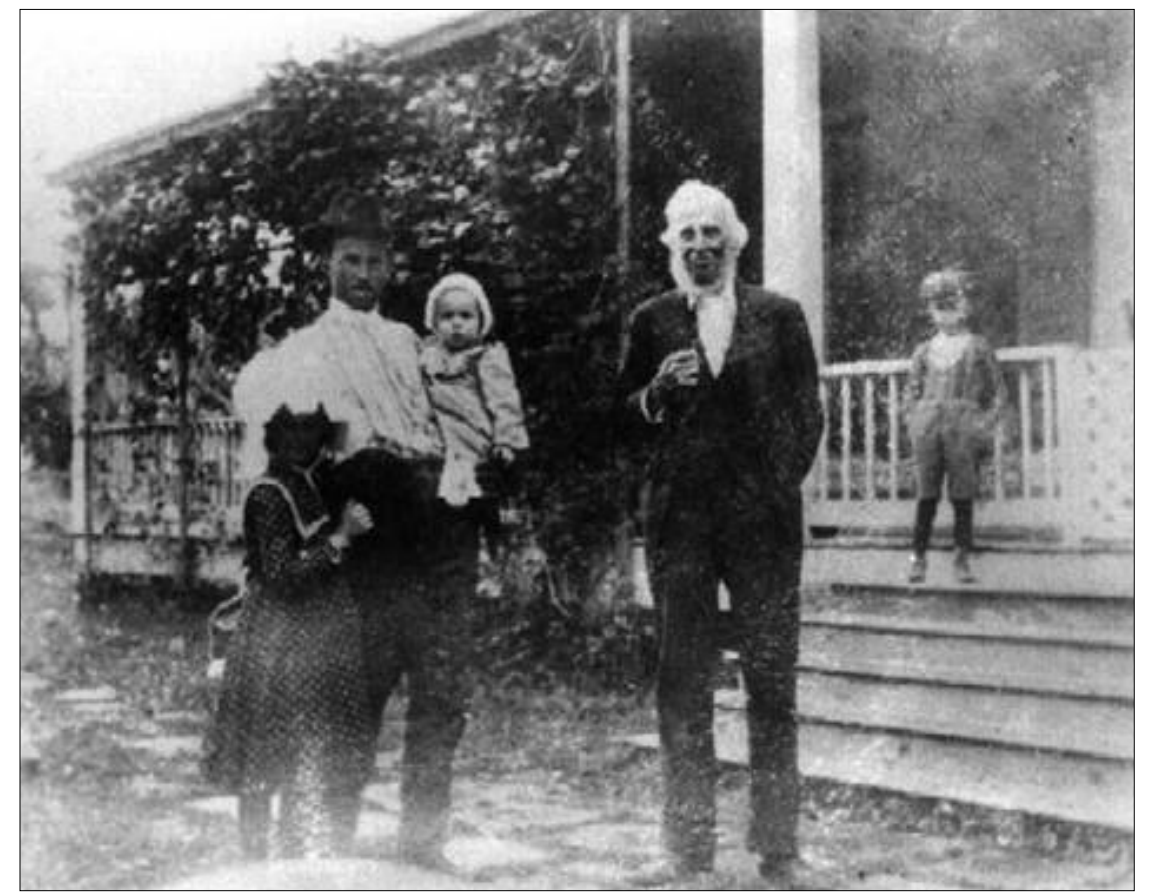

Figure 3-9. M. S. Munson (right) at Ridgeley Plantation.

Source: Brazoria County Historical Museum.

In addition to running his plantation, Munson managed a law practice with offices in Brazoria, Houston, and Galveston. His rising prominence in the community coincided with an increase in his plantation's operations. By 1860 , Munson had increased the area of cultivation to 160 acres bringing the total cash value of his farm to $\$ 20,000$. Munson continued to rely on livestock as a major source of revenue; in 1860 , he owned 300 cattle worth $\$ 5,785$. The plantation also included 50 horses, a sign of wealth within the plantation culture. Cotton production increased as well ( 60 bales), and was aided by the construction of a cotton gin, located in a field referred to as the "gin house field." Munson also grew tobacco, wheat, and potatoes. ${ }^{14}$

As he was often away on business, Munson assigned a slave, Ralph, the duty of overseeing the farming and ranching activities of the plantation. The 1860 slave census listed Munson as owning 28 slaves housed in five slave quarters. In the beginning, the Munsons constructed their slave quarters near their house, since slaves helped Sarah Munson with cooking, making clothes, and washing and ironing. As the plantation grew and more fields came under cultivation, they built slave quarters closer to work areas (Murray 1940).
In addition to owning a plantation and his law practice, Munson in 1857 served as a state representative in Austin. In 1861, Munson left the plantation to serve the Confederacy; during his absence, management of the plantation was assumed by Sarah Munson. Ridgeley Plantation represents the numerous small plantations that operated in Brazoria County, many of which only grew cotton because of the cheaper production costs.

Aside from these three representative plantations, the county included sugar and cotton plantations of varying wealth and size including Lake Jackson, China Grove, Chenango, Peach Point, and Waverly.

\section{Transportation and the Plantation Economy}

A key factor in the development of plantations in Brazoria County was its favorable access to markets. Early settlers located their homesteads near rivers and creeks knowing that water would be important to their commercial success. As a result, plantations in the county developed primarily

${ }^{14} 1860$ Agricultural Census, Texas State Library and Archives, Austin, Texas. 
along the Brazos and the San Bernard rivers, with large clusters along the Brazos River in the southern portion of the county. Figure 3-10 shows a plat map that illustrates how important rivers were to the siting of individual buildings. The map shows a sugar house, main dwelling, and an outbuilding situated alongside Oyster Creek.

As cotton and sugar cane crops expanded, rivers and creeks increasingly served plantation owners, as rafts, and later steamboats, were used to ship bales of cotton or hogsheads of sugar south to the merchants of Galveston. The Brazos River in particular emerged as the central route for the county's growing immigration, commerce, and communication needs. Boats penetrated as far inland as East Columbia, which became an important commercial site for planters; Brazoria and Velasco, situated along the Brazos, developed customhouses as a result of the growing commercial traffic. By 1840, Houston was attracting business away from the Brazos, prompting county leaders to expand transportation infrastructure. Finally, in 1857, a canal connecting the Brazos River to Galveston Bay was completed, greatly aiding the flow of commercial goods (Kleiner 2003a).

In addition to rivers, roads were an important component of plantation life. Many roads developed according to the location of existing plantations, with some planters building roads connecting neighboring plantations. Existing plat maps often show public roads in some way bordering or intersecting plantation sites as seen in Figure 3-11. An important source for communication, roads also enabled planters to travel in order to buy supplies or attend important business or political matters.

The county's growing wealth and the poor condition of many roads prompted leaders to pursue the construction of a railroad. Earlier attempts beginning in 1836 all failed, until 1856, when Brazoria County planters united with Houston

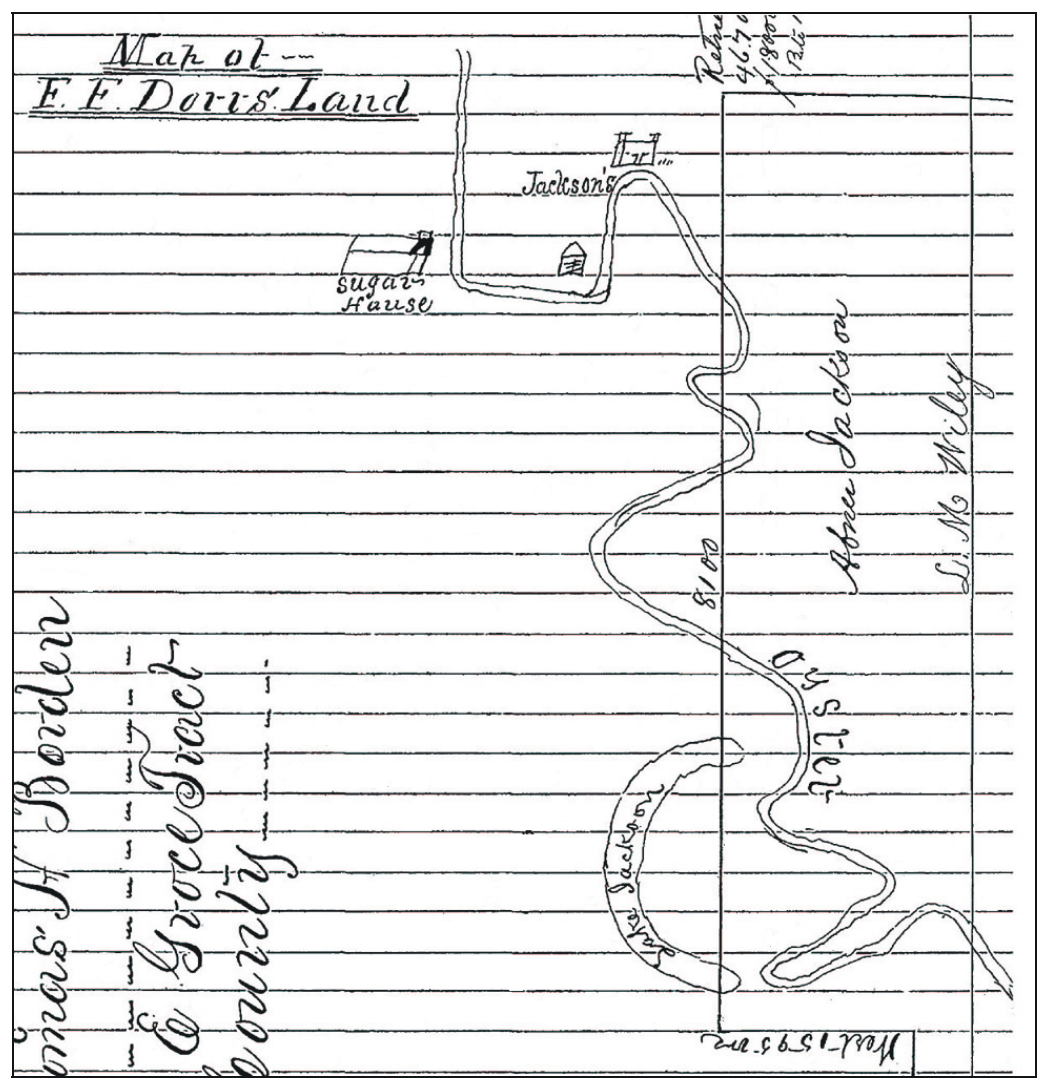

Figure 3-10. Plat map showing Abner Jackson's plantation with sugar house, residence and outbuilding flanking Oyster Creek.

Source: Brazoria County Courthouse. 


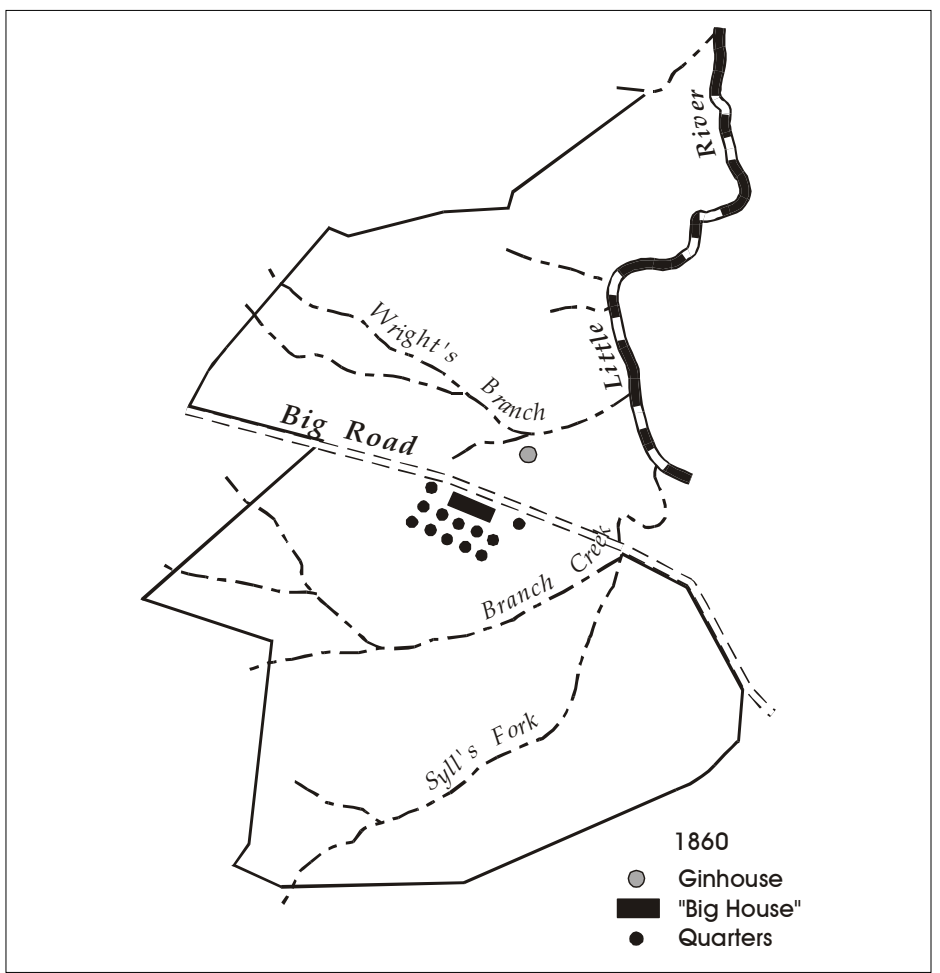

Figure 3-11. Map showing a public road adjacent to a ginhouse, residence, and slave quarters. Source: Iruegas (2003); redrafted.

merchants to charter the Houston Tap and Brazoria Railway Company. Known as the "Sugar Road" because it transported the county's commercial crops to the markets of Houston, the Houston Tap and Brazoria was completed by 1859 and connected Columbia with Houston. The use of slaves kept construction costs relatively low. Figure 3-7 shows the Houston Tap and Brazoria (shown as the International and Great Northern Railroad) on the southern border of the Willow Glen plantation. The railroad was heavily used until the outbreak of the Civil War, when the tracks were used to make revolvers (Creighton 1986: 213-215).

\section{Plantation Landscapes and Layouts}

As discussed previously, Brazoria County plantations often followed southern customs. Planters arranged their operations according to the wealth of knowledge they brought from southern states. With some exceptions, the outbuildings, main residences, slave cabins and fields of Brazoria County shared characteristics with those in Virginia, Tennessee, Louisiana, and other southern states. The architectural historian John Michael Vlach, however, notes that a range of factors created a variety of plantation landscapes. After looking at plantations across the South, he argues, "that it is more correct to speak of southern plantations rather than of the southern plantation" (Vlach 1993:193).

Nevertheless, certain overall trends in plantation design were evident: sugar estates were "largely industrial in character, whereas cotton plantations often resembled nothing more than oversized farms" (Vlach 1993:193). In other words, landscapes usually reflected the type of work performed; cotton plantations involved much less expensive equipment and smaller labor requirements than sugar, and as a result, the landscapes were simpler and less organized.

Most plantations included common elements like a large main residence, slave cabins, and outbuildings, which were often clustered together in a "gridlike pattern," known as the block plan. This configuration, identified by the geographer John B. Rehder, originated in the formal estates of Virginia and South Carolina. Other plantations were characterized by scattered outbuildings, or slave quarters that were far from the main house and closer to agricultural fields (Vlach 1993:6). As defined by landscape historians (Turner 1982:62), typical features included: 
1. Cultivated fields occupying the majority of the site;

2. The residence of the planter located in a prominent position;

3. Slave quarters clustered in a nodal or linear village form;

4. A highly developed service area near the planter's house, including a kitchen, woodpile, smokehouse, and other necessary utility areas;

5. A kitchen garden, usually sizeable, for the cultivation of foodstuffs for consumption by the planter's family and the slave population;

6. A transportation link with the market for the cash crop, whether a waterway or roadway; and

7. Ornamental planting, either an actual garden or simply rows of trees.

Regardless of placement, the elements were often coordinated to convey planter prestige, as well as a hierarchy of power. The austere nature of slave quarters, for example, was meant to remind inhabitants of their role within the plantation. Planters, displaying their wealth, adorned their residences with elaborate architectural detailing. An earlynineteenth-century account of Josiah Bell's plantation near East Columbia provides a vivid sense of a typical Brazoria County plantation landscape:

The entrance to the premises was from the north. Directly in front of the dwelling a stile over the lane fence admitted persons. A little further west a pair of bars admitted animals and carriages. The dwelling was about 200 yards west of the public road. West of the dwelling, some little distance from it, were the stock lots joined to the lane fence. In one of these were cribs for corn and the stables for horses. Between these and the house were the negro quarters, the blacksmith-shop, the smoke-house and the kitchen. These last were near to each other, and the kitchen only a few steps from the west end of the house.... The dwelling was a double log house of the style very much used in all the early settlements in the United States [McCormick 1897:113-114].
The following section will explore in further detail how planter and slave housing, as well as outbuildings were situated within the overall plantation landscape in Brazoria County.

\section{Housing}

As discussed previously, homesites were selected according to their proximity to a river, stream, or creek. Early settlers like James B. Bailey and Josiah H. Bell erected log cabins which suited the frontier nature of early Brazoria County (see Figure 3-12). By the mid-1840s, however, planters began to build more elaborate and permanent structures that served to display their growing wealth. The main house, or "big house," served as the epicenter of a social hierarchy that spread throughout the plantation (see Figure 3-13).

Slave housing typically followed the same evolution as the main houses, moving from log cabins to frame or brick construction and were usually bare of any comforts (see Figure 3-14). Though small in size, they typically housed an average of four to eight slaves. ${ }^{15}$ The location of slave housing usually depended upon the type of work slaves performed, with house slaves usually living in clustered quarters near the big house. Figure 3-11 illustrates such a configuration. Field slaves, however, were usually a quarter mile or more away from the main house and were situated near agricultural fields. On large plantations, it was not uncommon to see clusters of slave housing adjacent to each cotton or sugar field (Curlee 1932:238). Figure 3-15 shows the plan of a typical sugar plantation in which the slave quarters are situated in rows next to the cane fields. Some plantations like Bernardo in Brazoria County included slave communities that functioned like self-sufficient units, with tightly clustered slave quarters, a nursery building, and an overseer's house (see Figure 3-16).

\section{Outbuildings}

Plantation outbuildings included kitchens, smokehouses, blacksmith shops, barns, stables, dairy houses, corn cribs, and pig houses. They were usually located near the main house-one architect commented that outbuildings surrounded southern homes "as a litter of pigs their mother." The arrangement of the outbuildings typically followed a linear arrangement (Vlach 1993:77-78). Figure 3-12 shows such an arrangement of outbuildings.

Ginhouses and sugar mills were usually located near cotton or cane fields to facilitate the processing stage of cultivation.

151860 Slave Schedule, Texas State Library and Archives, Austin, Texas. 


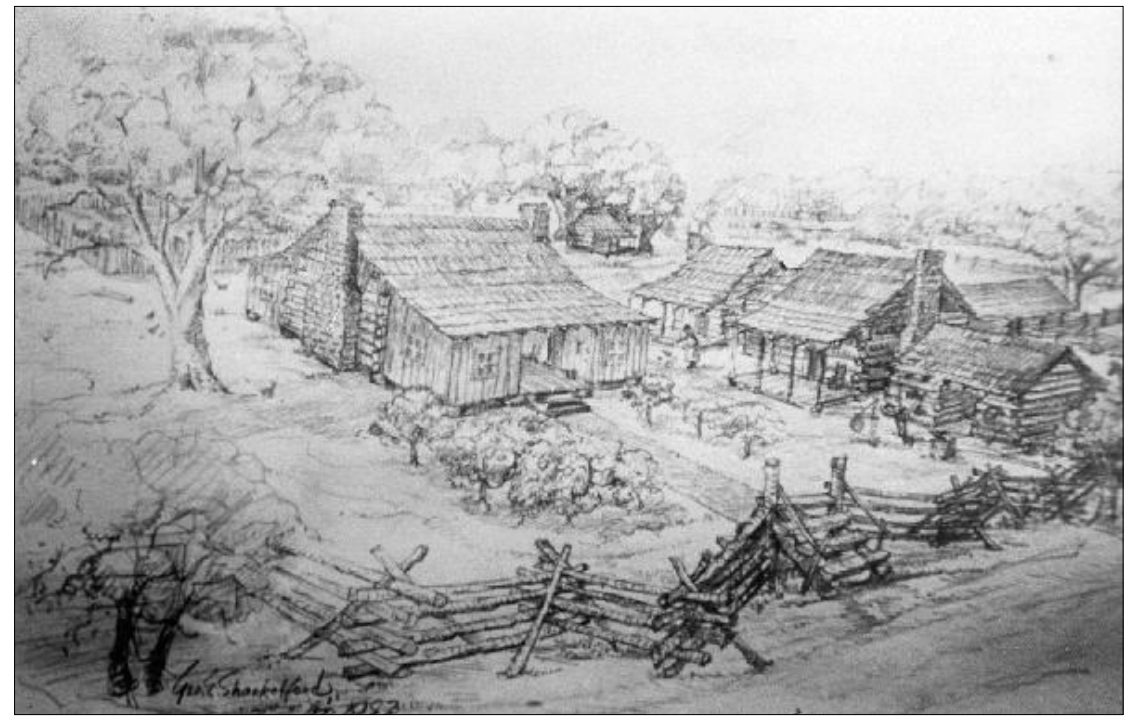

Figure 3-12. Drawing showing the Josiah Bell plantation, Brazoria County, circa 1830. Source: Brazoria County Historical Museum.

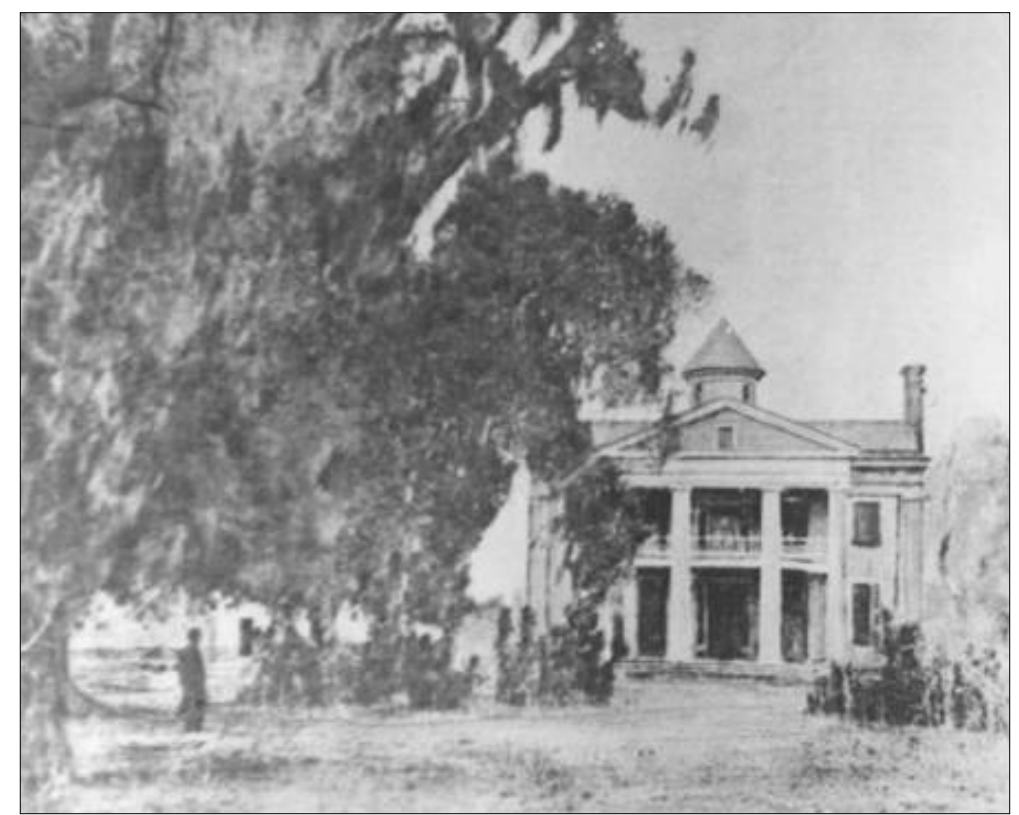

Figure 3-13. Abner Jackson's plantation home at Lake Jackson, Brazoria County. Source: Brazoria County Historical Museum.

Unlike ginhouses, which were usually small frame buildings, sugar mills dominated the landscape with their brick construction, two-story height, and towering furnaces. Figure 3-15 shows a sugar mill adjacent to the cane fields. Ginhouses and sugar mills were also situated close to roads, rivers, or railroads to ease the shipment of the bales of cotton and hogsheads of and sugar. An early-nineteenth-century account of Josiah Bell's plantation describes an example of how planters designed the relationship between public roads, agricultural machinery (ginhouse), and cotton fields: 
The relative situation of the fields to the dwelling house and to each other were the same, though each of the fields had been enlarged from time to time, as he added to his force of slaves. There were two main fields; the one extending north from the dwelling towards the prairie, called the prairie field, though little, if any, of it was prairie land; the other extending south, and called the lower field. Both these were west of the public road from Velasco through Brazoria and Columbia to San Felipe, which ran along the east fence of both, throughout the length of each, in a course nearly north and south. These fields were separated from each other only by an open lane, running at right-angles to the public road, and about one hundred yards north of the dwelling. There was a third field east of the public road and north of the line of the lane which separated the other two. This field was called the gin field, because in the southwest corner of it stood the cotton gin house [McCormick 1897:112-113].

The golden era of economic growth experienced by Brazoria County planters faltered with the arrival of the Civil War. The period of Reconstruction firmly ended the plantation period in Brazoria County and Texas.

\section{The Civil War and Reconstruction in Brazoria County}

Agriculture dominated life in antebellum Brazoria County and as a result, national matters received scant attention. By 1860 , however, the national debate over slavery was reaching a fever pitch throughout the state. Though Sam Houston, a unionist, was elected governor in 1859, a rising chorus of pro-secessionist voices, including prominent planters in Brazoria County, brought the issue to the forefront. On February 11, 1861, the population of Texas voted to secede from the Union, with $99 \%$ of Brazoria County residents voting for secession.

Compared to most southern states, Texas remained relatively untouched during the war. Aside from Union attacks on fortifications at Velasco and Quintana, and a federal blockade of the Texas coastline, the county saw little damage. The enlistment of much of the white male population of the county, however, had a tremendous effect on the agricultural output of the county. Plantation wives were forced to take over plantation operations, at the same time surviving constant shortages of food, materials, and labor (Kleiner 2003a).

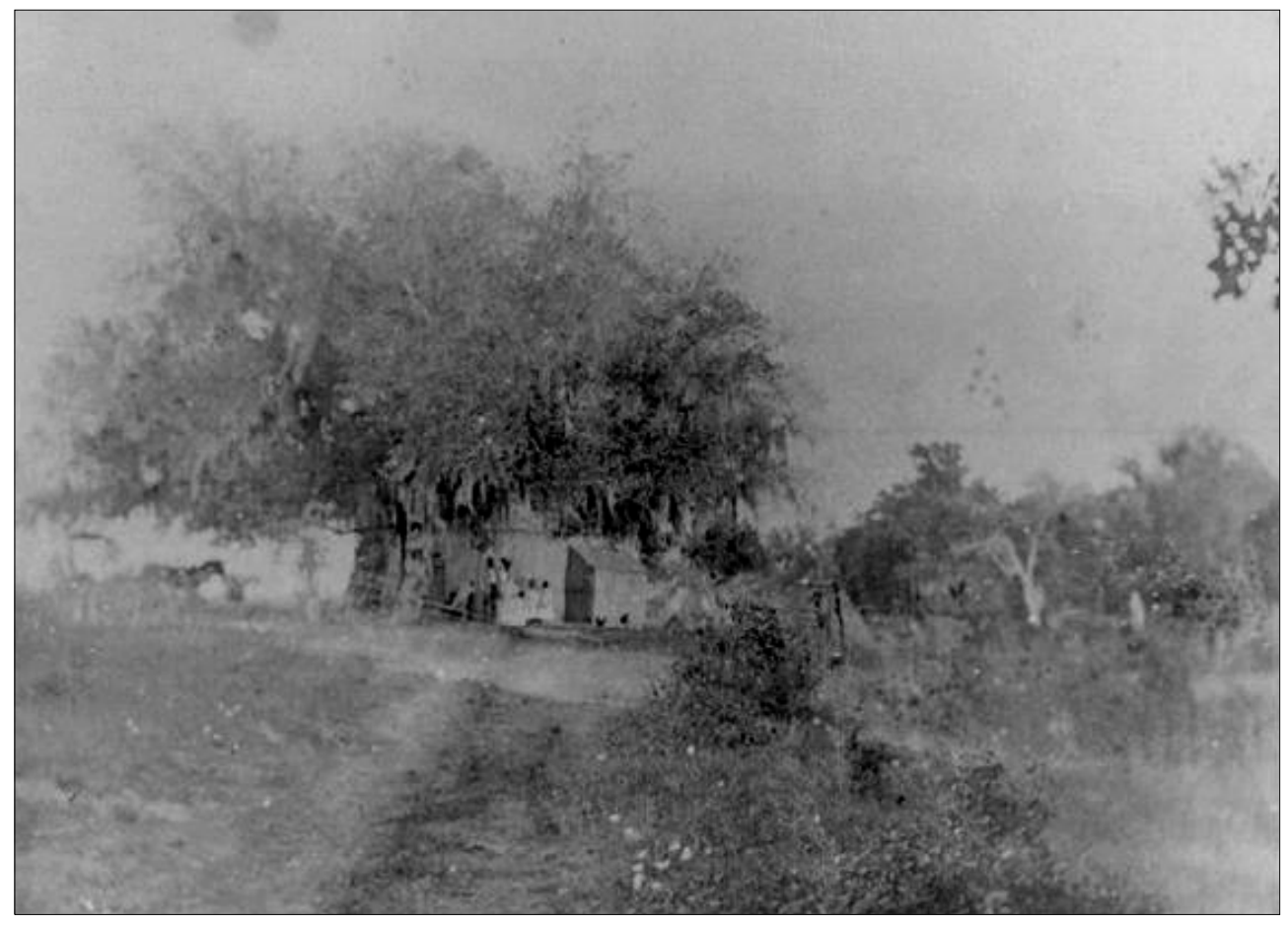

Figure 3-14. Slave cabin at Ridgeley Plantation, Brazoria County. Source: Brazoria County Historical Museum. 


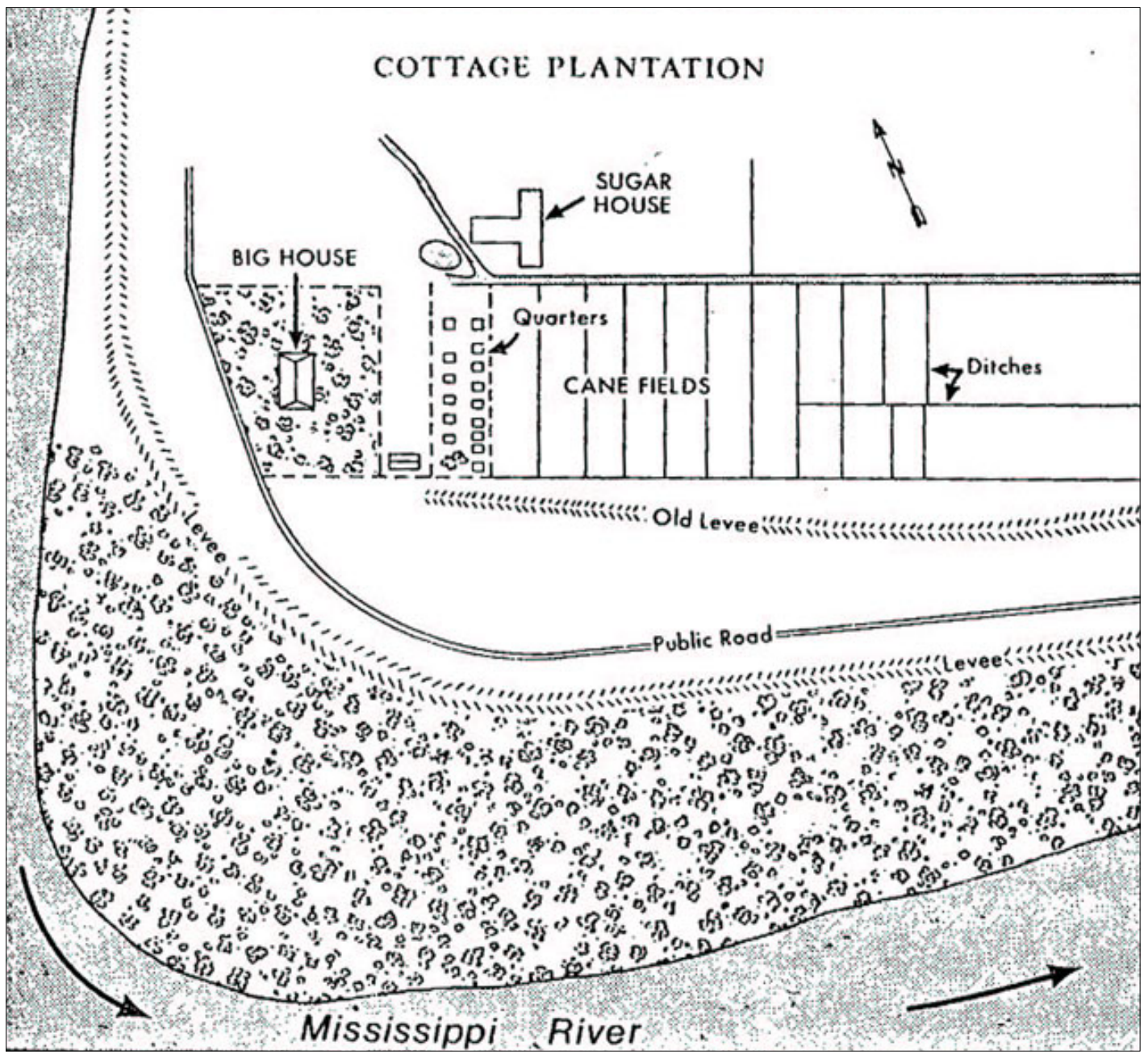

Figure 3-15. Typical sugar plantation layout showing location of slave quarters.

Source: Hilliard (1979:265).

The economic hardships of the war, however, paled in comparison to the immediate changes brought by the Reconstruction era. On June 19, 1865, General Granger, the commander for the District of Texas, formally announced the liberation of all slaves in the state. The order devastated planters across the county. The average slaveholder in the county lost $\$ 11,980$ when the slaves were freed. Some large slaveholders, like brothers David and Robert Mills, were financially ruined. Land values plummeted by a third by 1866; by 1870, values had dropped by two-thirds from their pre-war level. Overall property values fell from $\$ 7$ million to $\$ 2$ million from 1860 to 1866 (Kleiner 2003a; Powers 1994:93).

Without a suitable form of labor, many plantations across the county split into smaller farms. Fields, once overflowing in cultivated cotton and sugar, were converted to pasture land. Some planters simply escaped the new reality and fled to Mexico. For some Brazoria County planter families, the Tuxpan River Valley in Vera Cruz served as the new home for their plantations (Kleiner 2003a). Planters who stayed in the county faced a complete upheaval of their world.

Life for the freedmen was not much better. Though free, many met the news of their freedom with confusion-Texas' isolation during the war kept many slaves ignorant of national events. Freedom for many slaves meant uncertainty. Without marketable skills outside of agriculture, many freedmen saw little change in their future. Planters reacted differently to the news of their slaves being freed, with some accepting the news, and others determined to keep the new freedmen in a state of economic servitude. 


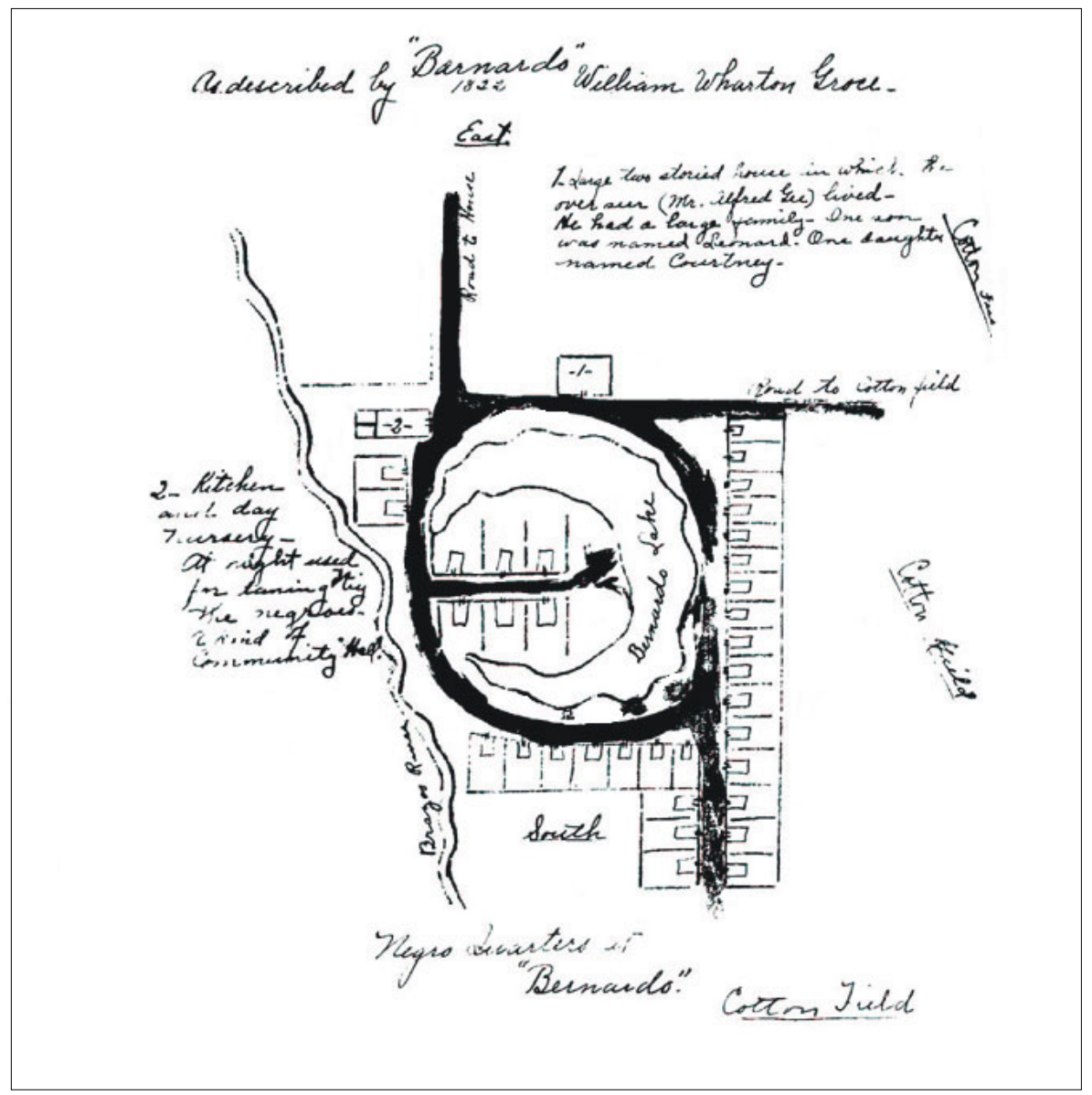

Figure 3-16. Slave community at Bernardo Plantation, Brazoria County.

Source: Curlee (1932).

\section{The Wage System and Sharecropping in Brazoria County}

Labor shortages in the Reconstruction era plagued the planters. Months after being freed, some slaves refused to work, others exhibited a lack of interest in cultivating their former master's lands. Some Brazoria County planters turned instead to Europe as a source for cheap labor. A small number of British, French, and Swedish peasants arrived in the county to work on the plantations, but soon quit because of low pay (Dorsett 1981:100). As a result, planters realized that freedmen were the only way to continue agricultural pursuits.

The Freedmen's Bureau, a national organization whose Texas branch opened in November 1865, attempted to facilitate planter and freedmen work relationships. To satisfy the freedmen, the Bureau limited the work day for male freedmen to ten hours. In addition, work contracts had to be certified by the Bureau before being instigated. Planters adopted the wage system in the months after the war. Wages for a month's work averaged $\$ 2$ to $\$ 10$. Freedmen disliked the wage system, as some planters were determined to pay as little as possible (Smallwood 1981:43-43).

After months of using the system, both planters and freedmen were eager to find a new arrangement. Planters realized that freedmen would work harder if they felt a level of ownership over crops and as a result, the county adopted a tenant farming or sharecropping system. Sharecropping provided freedmen with several options. If planters made available supplies and housing, freedmen received one-third or onefourth of the crops grown. Laborers that provided their own supplies received half of all crops. Sharecropping proved favorable to many freedmen by giving them a sense of 
ownership and freedom that the wage system did not. The labor contracts created between planters and freedmen were specific as to the terms of agreement which can be seen in the following labor contract between Brazoria County planter John Sweeney, Jr. and four freedmen:

This contract made and entered into this $1^{\text {st }}$ day of January 1868 between John Sweeney part of the first part and the undersigned freedmen parties of the second part for the cultivation of 120 acres witnesseth-That John Sweeney in his part agrees to furnish land, team and farming implements and feed for the same and to give the parties of the second part two-fifths of all the crops raised on said 120 acres. Except sweet potatoes of which they are to have half.

The parties of the second part agree to thoroughly cultivate the land assigned to them and gather and house the crop being at all times subject to the orders of said Sweeney as far as the kind of crop to be planted and the manner of cultivating the same.

They further agree to feed themselves and Mr. Sweeney on his part agrees to furnish bacon at the usual price -15 cents a pound to be paid out of their crop. They further agree that should they neglect their crop they will be liable to damages the amount to be decided by two disinterested parties one chosen by each party or by the agent of the Freedman's Bureau. This contract is to terminate when the crop is housed or divided. ${ }^{16}$

Though sharecropping provided freedman with increased autonomy over their lives, the reality for many was dire. If crops failed, freedmen were held responsible, thereby forcing many into debt. This form of dependence prevented many from breaking the cycle of poverty. Sharecropping remained the dominant system of agriculture throughout the state for the rest of the nineteenth century (Smallwood 1981:44-45).

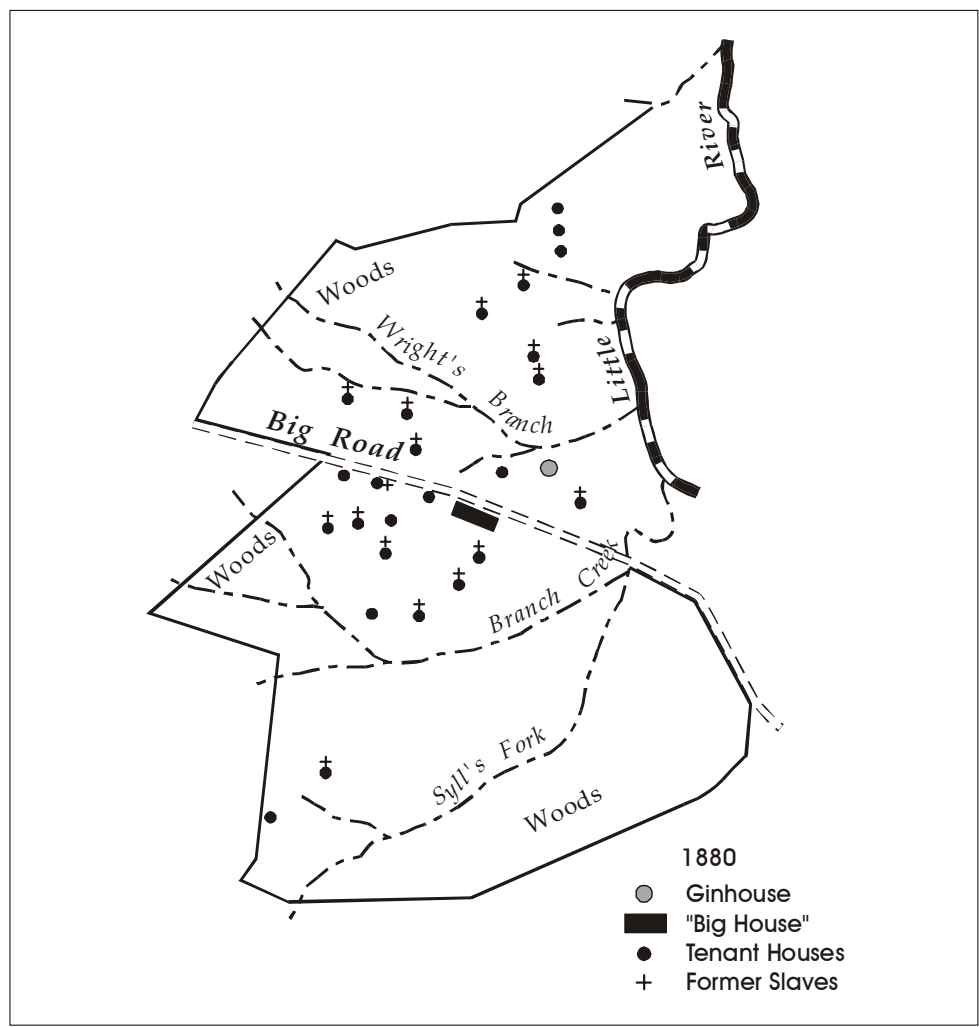

Figure 3-17. Postbellum settlement patterns indicative of the sharecropping system. Source: Iruegas (2003); redrafted.

\footnotetext{
${ }^{16}$ Brazoria County Historical Museum Archival Collections, Angleton, Texas.
} 
With the breakup of many plantations and the introduction of sharecropping, agricultural settlement patterns changed in the postbellum period. Tenant farming allowed freedmen to manage independent farmsteads rather than work in large groups as in the antebellum era. Tenant housing as a result was scattered across cultivated lands, rather than clustered in groups. Figure 3-17 shows the settlement patterns of freedmen as they appeared in the postbellum era. Figure 3-11 shows the antebellum period of clustered slave housing.

While the vast majority of Brazoria County freedmen remained stuck in the economic trap of sharecropping, a few managed to own land and maintain a level of success unknown to most former slaves. The freedman Charlie Brown emerged as the "wealthiest negro in Texas," shortly after the war. By the time of his death in 1920, Brown owned roughly 3,200 acres in Brazoria County. Nelson Crosby, also a freedman, raised cattle and horses successfully on land received by his parents from their former owners. Overall, 33 of the 1,332 freedmen families in Brazoria County owned land, a number indicating the tremendous economic barriers freedmen faced after the war. Other freedmen found positions of authority during the Republican-controlled Reconstruction era; however, the rising power of white vigilante groups like the Ku Klux Klan in 1866, limited such roles for blacks (Creighton 1986:261-264). In fact, options for most freedmen after 1866 were few indeed. Brazoria County leaders passed Black Codes that severely limited the economic, social, and political roles for freedmen (Smallwood 1981:54).

\section{Freedmen Communities in Brazoria County}

Despite the economic hardships associated with postwar Brazoria County, freedmen were eager to establish their cultural and religious independence. As part of this trend, freedmen communities across the state formed in the postwar years. The sites of these communities varied, with some forming on lands previously occupied by plantations and others developing on the outskirts of towns or cities.

Upon gaining their freedom, blacks across the state began to pursue educational and religious opportunities. With help from the Freedmen's Bureau, freedmen were moderately successful at establishing schools. Shortly after, churches were formed and included congregations made up of exslaves. In the majority of cases, freedmen rejected the congregations formed by their former masters and instead established their own services. These educational and religious developments grew into distinct communities of ex-slaves. For freedmen engaged in tenant farming, the new communities often developed on former plantation lands. Others tried urban areas for economic opportunities. In fact, the state witnessed a large migration to towns after the war, with one witness stating that freedmen wanted "to get closer to freedom, so they'd know what it was - like it was a place or a city" (Smallwood 1981:28). Houston, San Antonio, Austin, and Gonzales were all towns that witnessed the arrival of large groups of freedmen. As a result, these towns saw the gradual formation of freedmen communities.

The establishment of ex-slave communities in Brazoria County followed similar patterns as those that formed in the rest of the state. However, due to the lack of archival materials, a detailed understanding of the county's freedmen communities is not possible. Despite the lack of information, some trends can be established. Like counties in the rest of the state, Brazoria County witnessed the formation of numerous freedmen churches. One church was formed at Waldeck Plantation and included former slaves from the site. Other churches, the majority of which were Baptist, formed on the outskirts of small towns like East Columbia and Brazoria. Jerusalem Baptist Church, St. Paul Baptist Church and Bethlehem AME were examples of the roughly 13 freedmen churches in the county. It can be safely assumed that the location of the churches indicates where possible freedmen communities may have been located. Some Brazoria County freedmen were also likely to have been part of the migration to urban areas like Houston.

Recently, a freedmen cemetery was discovered at the site of the former Ebenezer Baptist Church near Bailey's Prairie. In addition to demonstrating the presence of freedmen communities in the county, the discovery also shows how much of the freedmen's history remains unknown (Angleton Times, 11 July, 1985).

\section{Agriculture in the Reconstruction Era, Brazoria County}

The economic hardships planters faced following the Civil War worsened when agriculture failed to spring back to prewar yields. The lack of labor and a depressed southern economy devastated agriculture in the county in the immediate postwar years. Crops during the period remained the same: corn, grain, sweet and Irish potatoes, fruits, cotton and sugar. Hardest hit was the sugar industry, which required a large supply of laborers. In 1867, one sugar planter commented: "the present crops are but about half an average, owing entirely to the impossibility of getting the negroes to 
work, for the season has been one of the best ever known" (Johnson 1961:40). Brazoria County produced only 1,423 hogsheads of sugar in 1869.

It was not until 1871 that the sugar industry returned to production levels consistent with prewar levels. The reason for the change was the use of convict labor, which the Texas legislature allowed in 1871. Plantation owners now had the option of leasing convicts to work on their sugar plantations. Planters viewed convict labor as more dependable than freedmen labor. The convict lease system significantly expanded in the $1880 \mathrm{~s}$; by the 1890 s, former plantations, like Retrieve and Darrington, became state prison farms (Johnson 1961:41).

Though cash crops like cotton and sugar showed signs of improvement by 1870 , cattle ranching emerged as an important component of economic life in Brazoria County. Many planters turned to ranching as a more stable pursuit in the postwar years and prospered as a result of the national market for beef (Murray 1940). Brazoria County was also home to an emerging canning industry—over $\$ 100,000$ of canned beef was produced in 1870 (Kleiner 2003a).

\section{Oil, Sulfur, and Petrochemical Developments in Brazoria County} Agriculture remained the dominant economic activity in Brazoria County until the emergence of oil and sulfur deposits in the early twentieth century. Oil production in the county began in 1902 after an oil field was discovered in West Columbia the year before. Production reached 12,500,000 barrels in 1921. By 1946, the county produced 29,308,106 barrels, making it the fourth largest producer among Texas counties. In 1906, a mining engineer, Bernard Baruch, discovered a sulfur mound along the Gulf of Mexico shoreline in Brazoria County. In 1912, using a recently developed sulfur mining technology, the newly organized Texas Freeport Sulphur Company began mining the sulfur mound, which became known as the Bryan Mound. Other sulfur deposits like Hoskins Mound and Stratton Ridge Dome emerged in later years and provided an economic boost to the region.

The sulfur industry in Brazoria County ranked first in U.S. production and made significant contributions to both world wars. In 1930, the Freeport Sulphur Company was extracting 2,000 tons of sulfur daily at the Bryan and Hoskins Mounds. By the end of World War II, sulfur mining in the county had been depleted; nonetheless, the company extracted 552,000 long tons of ore by 1944 (Kleiner 2003a). Figure 3-18 displays a circa 1940 map that locates oil and sulfur deposits throughout the county.

Despite the decline of the sulfur industry, Brazoria County in 1939 was fortunate to benefit from Dow Chemical Company's move to Freeport, which added the petrochemical industry to the economic portrait of the county.

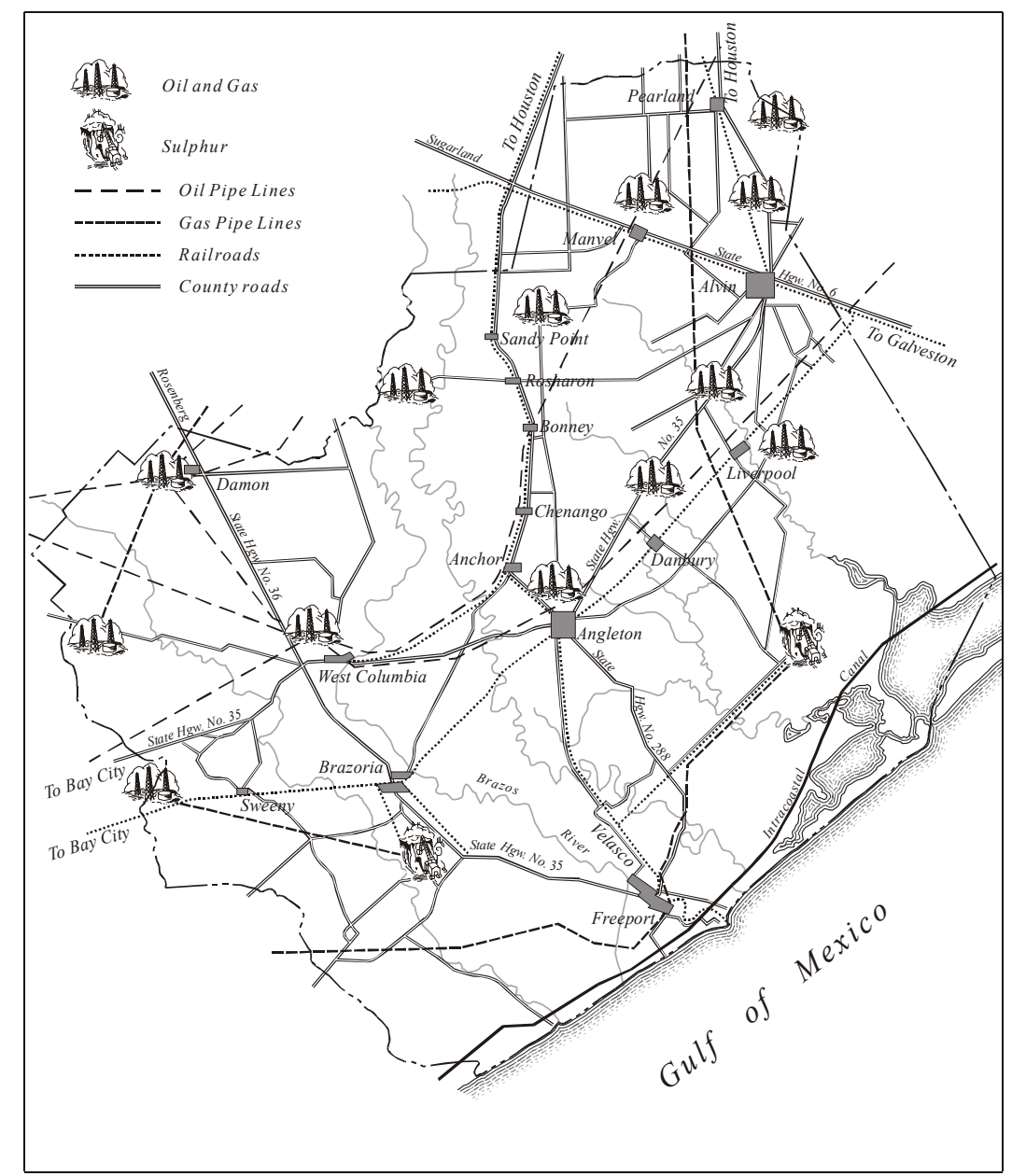

Figure 3-18. Oil, gas, and sulfur deposits in Brazoria County, circa 1940. Source: Brazoria County Historical Museum; redrafted from copy. 
The company quickly made an impact through its contributions to the war effort. In 1941, the Dow Chemical plant at Freeport began the commercial production of magnesium using sea water processed through electrolysis. The large production of magnesium proved vital for defense purposes and was used in airplanes, transportation, and textile industries. Shortly after, Dow expanded its magnesium production by creating a plant at Velasco, which also had easy access to sea water. The two plants combined produced 92,000 short tons of magnesium a year, in addition to producing refractory magnesia, magnesium chloride, caustic-calcined magnesia, and magnesium hydroxide. As a result, Brazoria County was responsible for more than $84 \%$ of the nation's production of magnesium. In the following decades, magnesium production at Dow continued at a fast pace (Kleiner 2003b).

As part of Dow's presence in Brazoria County, the community of Lake Jackson was established by the company in 1942 on plantation land formerly owned by Abner Jackson. The community grew quickly and today is one of the county's largest cities. During the war, Dow Chemical began the process of connecting its main plant at Freeport with outlying oil fields. The importance of oil and gas to their operations forced Dow to create an infrastructure easing its connections to oil and gas deposits. As a result, oil and gas pipelines running from deposits such as Old Ocean to Freeport began appearing at a fast rate. The old Bryan and Hoskins sulfur mounds were also tapped for their oil and gas as well. The new infrastructure eventually resulted in the formation of a new oil and gas branch of Dow called the Brazos Oil and Gas Division (Brandt 1997:186-187).

The Old Ocean oil field, discovered in 1934, was located near Sweeny, Texas, which in 1947 became the new location for a Phillips Petroleum plant. The company built a refinery, natural gas liquids center, and petrochemical complex at the site. Phillips remains a major employer of the region.

The shift from an agricultural-based to an industry-led economy significantly altered the physical landscape of the county. Several former plantation sites were discovered to later contain significant oil and sulfur deposits, including the Varner-Hogg Plantation site north of West Columbia. In 1990, Phillips Petroleum purchased the last plantation site owned by the same family since the antebellum period. The Sweeny plantation site included the original residence, and a slave cemetery in what is today Old Ocean. The site is currently surrounded by petrochemical plants and refineries. ${ }^{17}$ The Lake Jackson Plantation, of course, was later turned into Dow's company town, Lake Jackson. While some portions of former Brazoria County plantation land remain untouched by development and the petrochemical industry, many areas of the county have been adversely affected in past decades.

\footnotetext{
17 “John Sweeny," Vertical Files, Brazoria County Historical Museum.
} 


\title{
Chapter 4: Archeological Background
}

\author{
Richard B. Mahoney
}

This chapter briefly discusses the archeological background of the project area. To summarize the range of previously recorded sites in Brazoria County, the Texas Archeological Sites Atlas (THC 2003a) was consulted in August 2003. At that time, a total of 217 archeological sites had been recorded in the county. Of this total, only 159 site forms were complete. The remainder of the sites contained either "corrupted" data $(n=18)$ or Key Site Cards $(n=34)$ with limited or incomplete data; six sites contained no data whatsoever.

\section{Previously Recorded Sites}

To date, few investigations have been conducted in Brazoria County, resulting in the documentation of only 217 sites in the county, or only one recorded site per every 6.5 square miles. In comparison with surrounding counties, such as
Harris County with 974 recorded sites, or one site per every 1.8 square miles, archeological sites in Brazoria County are clearly under-represented.

A probable explanation for the relative paucity of recorded archeological sites is the comparatively lower modern population density and associated construction and development of the landscape. Specifically, while Brazoria County is roughly $80 \%$ of the area of Harris County, the current population of Brazoria County is only $6 \%$ of that of Harris County. Figure 4-1 depicts that, with few exceptions, counties with high modern populations densities also have a higher number of recorded sites. Thus, with few exceptions (i.e., Chambers and Jackson counties), the current population of a given county along the Texas Gulf Coast is more or less proportional to the number of recorded archeological sites (Table 4-1).

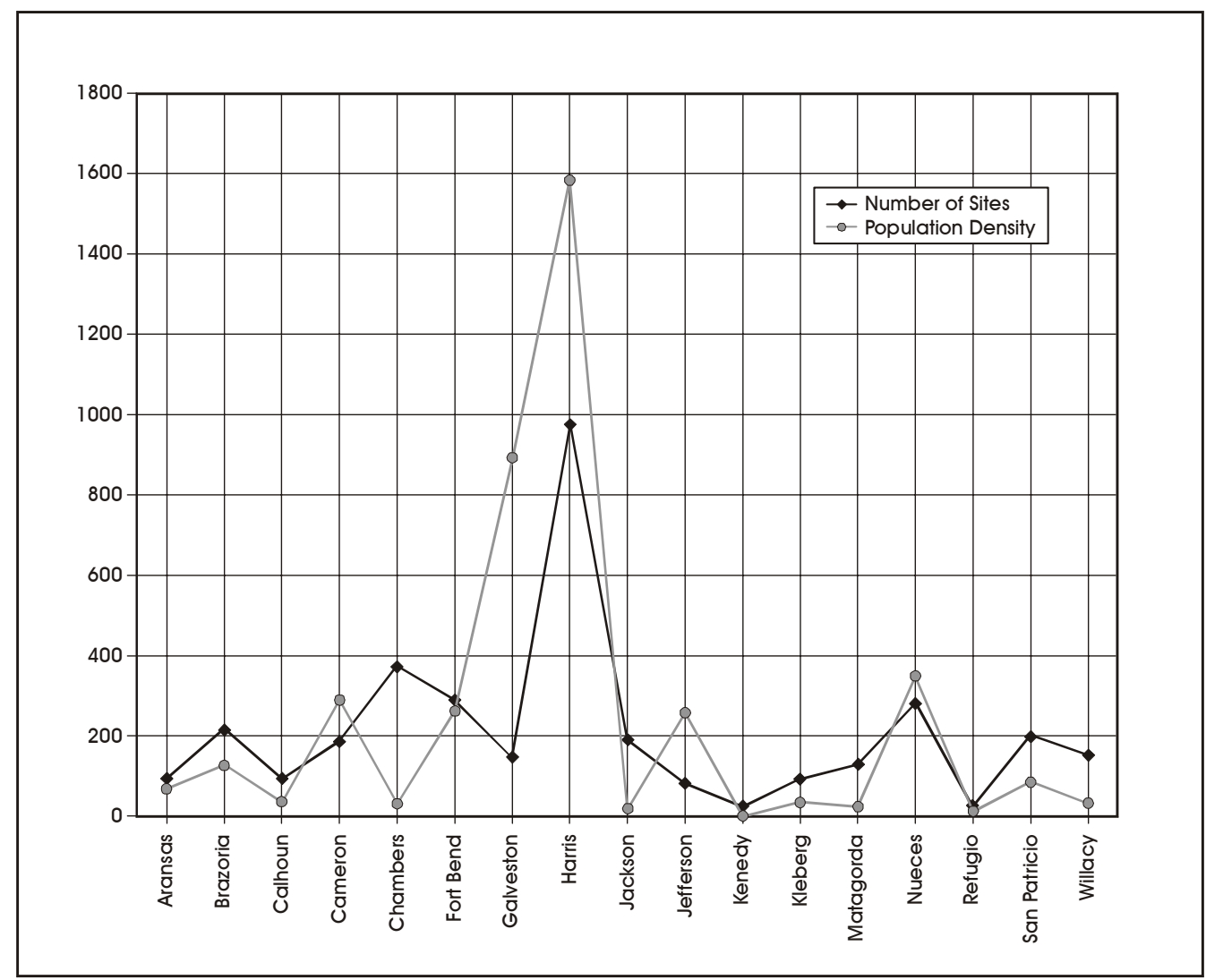

Figure 4-1. Number of recorded sites and modern (1990) population densities of coastal counties. 
Table 4-1. Number of recorded sites, area, and population of coastal counties

\begin{tabular}{|l|c|c|c|}
\hline \multicolumn{1}{|c|}{ County } & $\begin{array}{c}\text { No. of } \\
\text { Recorded Sites }\end{array}$ & $\begin{array}{c}\text { Area in } \\
\text { Square Miles }\end{array}$ & 1990 Population \\
\hline Aransas & 92 & 276 & 17,892 \\
\hline Brazoria & 217 & 1,407 & 182,244 \\
\hline Calhoun & 94 & 540 & 19,053 \\
\hline Cameron & 185 & 905 & 260,120 \\
\hline Chambers & 372 & 616 & 19,100 \\
\hline Fort Bend & 291 & 869 & 225,421 \\
\hline Galveston & 147 & 225 & 200,000 \\
\hline Harris & 974 & 1,778 & $2,818,199$ \\
\hline Jackson & 188 & 844 & 13,039 \\
\hline Jefferson & 80 & 937 & 239,397 \\
\hline Kenedy & 22 & 1,389 & 460 \\
\hline Kleberg & 94 & 853 & 30,274 \\
\hline Matagorda & 128 & 1,612 & 36,928 \\
\hline Nueces & 284 & 847 & 296,527 \\
\hline Refugio & 23 & 771 & 7,967 \\
\hline San Patricio & 201 & 693 & 59,288 \\
\hline Willacy & 150 & 589 & 17,705 \\
\hline
\end{tabular}

\section{Prehistoric Sites}

Of the 217 sites recorded in Brazoria County, 114, or 53\%, contain a prehistoric component. The vast majority $(\mathrm{n}=98$, $86 \%$ ) of these prehistoric sites include marine/estuarine shell middens. Fifty-eight (59\%) of these sites exhibiting shell middens are comprised primarily of Rangia cuneata, a brackish water clam; $25(26 \%)$ of the shell midden sites contain predominately oyster; and the remaining $15(15 \%)$ shell midden sites contain a comparable mixture of the two mollusks. Sites with lithic scatters as the predominant recorded expression constitute the bulk of the remainder $(n=13)$ of non-shell midden prehistoric sites. Two human burials and a single aboriginal ceramic scatter round out the assemblage of recorded prehistoric sites in the county.

Most ( $\mathrm{n}=60,53 \%)$ of the Brazoria County prehistoric sites cannot be assigned to a particular temporal period or phase. An overwhelming majority (98\%) of the remaining 54 sites can be assigned to the Late Prehistoric period. All but one of these 53 Late Prehistoric sites contain aboriginal ceramics, with the remaining Late Prehistoric site containing a single Scallorn arrow point. Five of the sites containing pottery also have associated diagnostic arrow points.
A single Protohistoric period site consists of a Rangia and oyster shell midden site along the San Bernard River. This site is attributable to the Protohistoric period due to the recovery of an untyped or untypable arrow point knapped from clear glass. Other material recovered from this site includes ceramic sherds, lithic debitage, animal bone, and glass shards.

Although the Damon Mound sites (41BO21 and 41BO25; Hester 1980) may represent an exception with their possible Paleoindian components, the scarcity of components predating the Late Prehistoric period within the county is intriguing. One possible explanation for their absence is the formational processes of the Brazos Delta (i.e., Espey, Huston \& Associates 1996). As the physiography of the northwest Gulf Coast responded to the dramatic paleoenvironmental changes occurring throughout the late Pleistocene and on through the early and middle Holocene, countless numbers of former occupation sites must have either been washed into the Gulf or are now deeply buried beneath seawaters (cf. Hester 1980). Similarly, deltaic formational processes have been demonstrated to deeply bury early Holocene deposits inland as deep as 20 meters below the current ground surface (Abbott 2001). 
Each of the recorded Brazoria County prehistoric sites are in proximity to a current or former meander of a stream. The county is devoid of natural resources of chert, which would obviate existence of highly visible lithic procurement sites located far from potable water. As such, habitation and mortuary sites are the only prehistoric site types so far encountered in the county. The largest number $(n=31,27 \%)$ of these sites occurs along the San Bernard River. Other streams or bodies of water along which numerous prehistoric sites have been recorded include Oyster Creek $(n=19)$, Chocolate Bayou ( $\mathrm{n}=14)$, Bastrop Bayou $(\mathrm{n}=11)$, and the Brazos River $(\mathrm{n}=10)$.

Accordingly, the landforms atop which these sites occur are related to and formed as a result of fluvial processes of the associated stream. Of the 114 prehistoric sites, 108 (95\%) are recorded atop terraces, levees, or ridges. These settings include remnant landforms associated with former channels of large meandering streams such as the Brazos River, Oyster Creek, and the San Bernard River. Ridge and swale topography is most evident in the numerous Rangia shell middens located atop ridges north of Shy Pond, a former meander of Oyster Creek (Hamilton 1988). Similarly, occupation sites atop former levees are represented with sites along Austin and Bastrop bayous (Castille and Whelan 1986).

\section{Historic Sites}

Of the 217 previously recorded sites in Brazoria County, 43 contain primarily or solely historic components. Ages of recorded sites span the Mexican Republic period through the twentieth century. The earliest recorded site is the James Briton Bailey Plantation (41BO190) established in 1818, and the latest recorded site is the shipwreck of the George Vancouver (41BO183), with a build date of 1942.

Numerous historic site types comprise the assemblage in Brazoria County (Table 4-2). Antebellum plantations constitute the greatest number, with a total of $10(23 \%)$ recorded as archeological sites. Nine (21\%) sites consist of artifact scatters or deposits not associated with structural or foundation remains. Historic shipwrecks account for six (14\%) sites. The remaining $42 \%$ of recorded historic sites includes cemeteries $(n=5)$; structures $(n=5)$; military sites $(\mathrm{n}=3)$; industrial sites $(\mathrm{n}=2)$; communities $(\mathrm{n}=2)$; and one corridor.

Antebellum plantations include large-scale and specialized sugar cane and cotton plantations that were common in
Brazoria County during the nineteenth century. Archeological research on some of these plantations within Brazoria and neighboring counties, such as the Varner-Hogg (Patton) Plantation (Earls and Tomka 1994), the Levi-Jordan Plantation (e.g., McDavid 1997), the Anson Jones Plantation (Carlson 1995), and the Lake Jackson Plantation (Few 1999) have contributed and are continuing to contribute valuable information to our understanding of the economic role and social impact of these plantations on communities and regions.

Two historic properties, the Munson Cemetery and the Bailey Plantation (41BO190), are indicated near, but outside, the Section 1 ROW on the THC Historic Sites Atlas (THC 2003b), and the corridor also crosses or passes near portions of the Sweeny Plantation (41BO109), Ridgeley Plantation, Bynum Plantation, Josiah Bell Plantation, and the Ward or Old Jones Plantation. The THC map files indicate the Jamison Cemetery, located south of the Section 2 ROW, and the African-American Morris Family Cemetery, located west of the Section $3 \mathrm{~b}$ ROW, as two historic cemeteries in the general vicinity of the project area. Section 3a has four known historic properties in its vicinity but outside of the immediate ROW. Bell's Landing was founded in 1823 as a Brazos River landing for the Josiah H. Bell plantation. It is located on the right-descending bank of the Brazos River south of the ROW. Carry Nation's Hotel was established in 1880 on the left-descending bank of the river in East Columbia. The Dance Brothers Gun Factory and Shop (41BO174), in East Columbia, was established in the late 1850 s to serve the Confederacy. Only foundations remain of the buildings that formerly stood on the leftdescending bankline of the Brazos River. Finally, there are two other known historic sites immediately west of the western portion of Section 3a, site 41BO185 and the site of the First Capitol of the Republic of Texas. Site 41BO185, introduced earlier, is a possible Civil War-era campground located north of SH 35 and just east of West Columbia. The structure that actually became the First Capitol of the Republic of Texas in 1836 was built around 1833. This structure was destroyed in the 1900 storm and a replica was erected on the original site in 1976-77. The site is near downtown West Columbia.

\section{Previous Investigations}

Professional archeological excavations within the current political bounds of Brazoria County have been limited. The first sites investigated were the Shy Pond Sites (41BO13 and 41BO15) excavated in 1967 by the Texas Archeological 


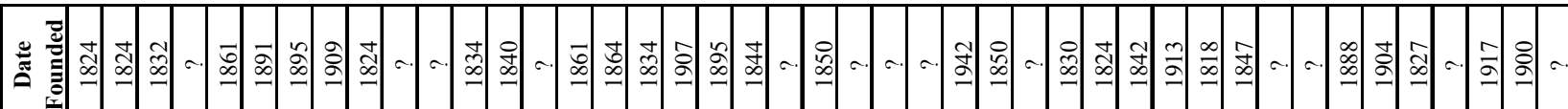

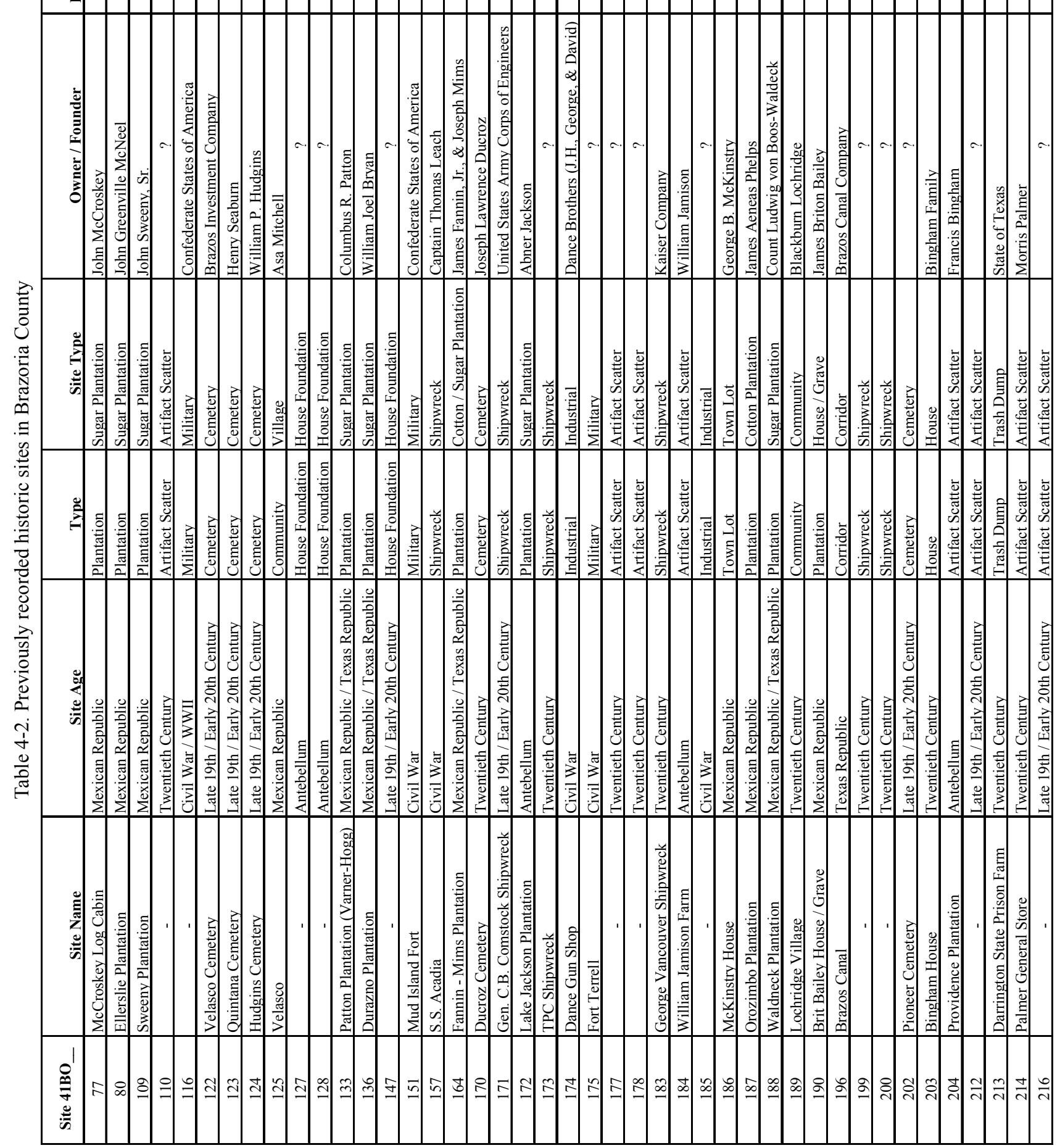


Research Laboratory (TARL) of The University of Texas at Austin (Hamilton 1988). The two sites were among several sites atop sandy ridges to the north of the pond. Hamilton (1988:80) describes the formation processes of these sites within the ridge and swale topography as a sequence of occupation responses to the receding meander of the Brazos River. Each of the investigated sites, as well as the majority of the surrounding sites, is comprised of one or more Rangia shell middens, often with associated aboriginal ceramics, indicating a predominately Late Prehistoric occupation of this portion of the Brazos River delta.

In 1970, the Texas Archeological Salvage Project (TASP) of The University of Texas at Austin conducted fieldwork at the Dow-Cleaver site (41BO35) along the left-descending bankline of the Brazos River (Aten 1971). With stratified Rangia shell deposits, representing the majority of the span of the Late Prehistoric along the Texas Coast, 41BO35 produced an abundance of aboriginal ceramics. Scallorn arrow points, associated with the Initial Late Prehistoric phase (Ricklis 1995:284), were recovered in association with plain, sandy paste ceramics in the earlier deposits. Perdiz arrow points, representative of the succeeding Rockport phase, were attributed to the later deposits.

Aten (1979) returned to Brazoria County in 1971 to further investigate sites along Oyster Creek, Lake Jackson, and Shy Pond. Site 41BO4 occurs along the right-descending bankline of Oyster Creek less than four miles from the Gulf of Mexico and, as such, produced a variety of shellfish, including Rangia cuneata. Stratified deposits of Rangia were also encountered at 41BO50, located approximately 14 miles inland on the eastern bank of Lake Jackson. The Shy Pond sites included 41BO12 and 41BO21, with the former producing aboriginal ceramics spanning the Initial Late Prehistoric phase through the Rockport phase.

During the same year, Dr. Frank Hole of Rice University lead an archeology field school at 41BO2, the Shell Point site (Hole and Wilkinson 1975). Five human burials were recovered from the oyster shell midden near the mouth of Chocolate Bayou. While no lithic artifacts were encountered, recovery of numerous $(n=136)$ sandy paste ceramics indicates affiliation with the Initial Late Prehistoric phase. A single asphaltum decorated sherd, however, suggests that a later Rockport phase component may have existed, albeit briefly.

The Anthropology Research Laboratory of Texas A\&M University conducted test excavations at 41BO126 along
Oyster Creek in 1977 (Dering and Ayers 1977). The site was identified during limited survey at the Village of Oyster Creek earlier that year by the Texas Water Quality Development Board (Whitsett 1977). Site 41BO126 consists of diminutive Rangia shell middens and sandy paste Goose Creek aboriginal ceramics. Two radiometric dates place the occupations of the site within the Initial Late Prehistoric phase. While the material culture recovered at the site was relatively sparse. Dering and Ayers (1977:68) suggest a cyclic subsistence pattern wherein coastal peoples would exploit marine and/or estuarine resources, travel inland via waterways, camp intermittently, and ultimately exploit the flora and fauna of their inland destination.

Data recovery excavations were conducted at the Jones Lake site (41BO79) along the right-descending bankline of Jones Creek (Espey, Huston \& Associates 1996). These efforts were performed to mitigate the effects of development of the Gulf Intracoastal Waterway and represent the first intensive work in the county in nearly two decades. Recovery of Perdiz and Bulbar Stemmed arrow points, grog-tempered aboriginal ceramics, and radiometric dating place the bulk of the occupation within the Late Prehistoric Rockport phase.

A variety of surveys associated with the $\mathrm{SH} 35$ corridor project proper have been conducted since 1993. A review of the Texas Archeological Sites Atlas for the survey area indicates two sites (41BO184 and 41BO185) within the corridor; 41BO185 was determined ineligible for nomination to the National Register of Historic Places in 5/22/2000 (THC 2003a). However, a number of additional sites are located in the immediate vicinity of the project. The known site that is within the ROW is 41BO184, a multicomponent prehistoric open campsite and historic plantation site located on the left-descending bankline of Oyster Creek within Section 2 of this survey. The cultural materials of the prehistoric component found at the site consist of lithic debitage, prehistoric ceramics, mussel shell, and bone concentrated within a 20 -cm-thick zone buried between 40-60 cmbs. A total of 10 shovel tests was excavated in the site at the time of the original survey. More recently, Allen Bettis of the Environmental Affairs Division of TxDOT excavated additional shovel tests and shallow backhoe trenches in 41BO184. While these tests produced prehistoric material, they also identified a discrete component of historic ceramic and faunal remains that may be associated with Steven F. Austin's “Old 300" colonist's plantation settlement. TxDOT Archeologist Al McGraw identified these as antebellum, possibly Republic of Texas, and Sergio Iruegas, formerly of the Texas Historical Commission, agreed with the identification based on the historic ceramics. 


\title{
Chapter 5: Methodology
}

\author{
Richard B. Mahoney
}

This chapter discusses the methods used in implementation of the archeological investigation. Each general step of the process is presented and includes sections concerning the initial literature review, field methods, and laboratory methods. The field methods section is further divided into subsections describing the pedestrian survey, mechanical auger boring, and backhoe trenching.

\section{Literature Review}

The archeological research commenced with a comprehensive review of all available archeological reports and databases to identify and characterize all archeological sites known to occur in the general vicinity and within the project area. At least in part, the compilation of the known prehistoric sites within and in the vicinity of the project area is based on the Texas Archeological Sites Atlas and THC map files that contain information on all sites recorded within each county in the state. As part of this effort, an archeological literature review was performed to summarize information on the types of prehistoric and historic sites and the characteristics of the regional prehistoric settlement patterns. The literature and archival review also inspected United States Geological Survey (USGS) topographic maps, the USDA Soil Conservation Service's Soil Survey of Brazoria County (Crenwelge et al. 1978), Flood Insurance Rate Maps (FIRM), and Abbott's (2001) Houston Area Geoarcheology to define the geomorphic history of the project area and establish the age and depositional history of the deposits. Recent project-specific aerial photographs were assembled for the delimitation of the project area in an ArcView database. This baseline was used to define the precise limits of the project area, map previously recorded prehistoric and historic properties, and define stream crossings that are likely to contain minimally disturbed or undisturbed buried deposits.

\section{Field Methods}

The goals of the field survey were twofold: (1) locate all prehistoric and historic archeological sites within the APE buried to a depth of project impacts, possibly a depth of 1.5 $\mathrm{m}$ below the surface or maximum practical depth of the mechanical equipment; and (2) establish vertical and horizontal site boundaries and define the depth of cultural materials within deposits contained in the APE's depth of project impacts. The depth of $1.5 \mathrm{~m}$ was established for subsurface trenching because cross-sections detailing cut and fill geometry were unavailable at the time of research design development, and $1.5 \mathrm{~m}$ is a conservative estimate of the depth of impact of a surface highway project in this environment based on typical highway design.

For the purpose of this survey, sites are defined as locations having at least five artifacts within a $30-\mathrm{m}^{2}$ area, or as a location containing a single cultural feature such as a hearth. All other artifacts are classified as isolated occurrences.

The intensive survey utilized a combination of techniques including $100 \%$ pedestrian survey, intensive mechanical augering, backhoe trenching, and hand-excavated shovel tests. Mechanical augering and backhoe trenching were employed primarily to search for buried archeological deposits (i.e., as site discovery techniques) within the thick, recent Holocene alluvial deposits.

\section{Pedestrian Survey}

The pedestrian survey consisted of two crews of two persons each walking varying lengths of the project area. One hundred percent of the project area was subject to this pedestrian survey. Individual transects were spaced at 15-m intervals, with each section receiving at least two transects along each side of the highway subject to ROW expansion.

\section{Mechanical Auger Excavations}

Mechanical augering to $120 \mathrm{cmbs}$ was conducted using a Bobcat ${ }^{\mathbb{R}}$ MT50 equipped with a 4-ft-long and 9-in-diameter auger bit. Each auger boring measured roughly $23 \mathrm{~cm}$ in diameter. The auger tests were spaced $100 \mathrm{~m}$ apart along the entire linear project area. Within the detention ponds, the rate of auger boring excavations matched the required rate of shovel tests per acre. That is, hand-excavated shovel tests were replaced with mechanical auger borings at a 1:1 ratio. As in the linear ROW, the goal of these auger borings is site inventory completion (i.e., site location and boundary definition). 
The auger borings were excavated in two general levels, one covering 0 to $60 \mathrm{cmbs}$, and a second section covering 60 to $120 \mathrm{cmbs}$. The matrix derived from the auger borings was to be screened only if clay did not dominate the sediments. As clay dominated the sediments encountered in each of the auger borings, though, none of the matrix was subject to screening. The excavated sediments were, however, carefully examined for cultural material or evidence of cultural deposits, features, or occupation.

Within areas identified by HHM (2003) as associated with antebellum plantations, mechanical auger borings were excavated in one general level, covering from ground surface to $60 \mathrm{cmbs}$. Within this portion of Brazoria County, this depth has been shown to contain the majority of historic deposits, with some dating to the antebellum era (Mahoney 2003a) and historic cultural features dating to possibly the Civil War era (Dismukes 2003). Similar to the remainder of the project area, as clay dominated the sediments encountered in each of the auger borings, none of the matrix was subject to screening. The excavated sediments were, however, carefully examined for cultural material or evidence of cultural deposits, features, or occupation.

\section{Backhoe Trenching}

Given the deep recent Holocene deposits that blanket the region, it is assumed, based on Abbott's (2001) geomorphic work, that most of the prehistoric sites, even of Late Prehistoric affiliation, may be buried at some depth below the modern surface. Therefore, in addition to the mechanical augering efforts, one technique that can aid site discovery is systematic backhoe trenching. As such, backhoe trenches were placed at a rate of one per every $150 \mathrm{~m}$ in Sections 1 and $3 \mathrm{a}$, the two sections located in bottomland settings. Backhoe trenches were excavated at a rate of one per every $200 \mathrm{~m}$ in Sections 2 and $3 \mathrm{~b}$, since these locations are on somewhat higher ground.

The purpose of the backhoe trenching was to determine the presence, absence, and stratigraphic context of cultural resources in the upper $1.5 \mathrm{~m}$ of project ROW. The soils and sediments exposed in the trench walls were examined and interpreted as to depositional environment, pedogenic composition, and potential archeological context. The project geoarcheologist was responsible for describing the depositional stratigraphy of representative trenches.
Most backhoe trenches measured 4-5 $\mathrm{m}$ in maximum length and $1.5 \mathrm{~m}$ in depth. This depth is a conservative estimate of the expected maximum depth of impacts due to surface construction. Within $50 \mathrm{~m}$ of major streams (the Brazos River, the San Bernard River, and Oyster Creek) and $25 \mathrm{~m}$ of bayous (Dry Bayou, Middle Bayou, Mill Bayou, and Varner Creek) where bridging or bridge-class culverts will be necessary, mechanical excavation continued to the practical limits of the excavation equipment or until groundwater inflow rendered further excavation untenable. At least one trench was excavated on or near each bankline of these streams. While none of the excavated matrix was screened, the backdirt and cut surface were monitored throughout. None of the trenches were entered below a depth of $1.5 \mathrm{~m}$.

\section{Laboratory Methods}

All documentation produced as a result of the survey field efforts were curated at the CAR permanent storage facility. Field notes, forms, photographs, and drawings were placed in archivally stable folders. Photographs, slides, and negatives were placed in archival-quality sleeves. All folders and sleeves were stored in file cabinets. Documents and forms were printed on acid-free paper. A copy of the survey report and all computer disks pertaining to the investigations were curated with the field notes and documents. No artifacts were collected. 


\title{
Chapter 6: Results
}

\author{
Richard B. Mahoney and David D. Kuehn
}

This chapter presents the results of the cultural resources and geomorphological investigations. As previously discussed, the overall project area was originally divided into three sections, 1-3, with Section 3 consisting of Sections $3 a$ and $3 b$. Based on these divisions, the archeological and geomorphological results from each section are presented individually. In addition to the archeological field efforts expended In each individual section, the results of the additional, intensive auger borings of the antebellum plantations also are presented.

\section{Archeological Investigations}

\section{Section 1}

A total of 121 auger borings and 76 backhoe trenches were excavated in Section 1 (Table 6-1). Eighty-six of the auger borings were located along the linear portion of the section and 35 were dug within the two detention ponds. Fifty-six of the backhoe trenches were located along the linear portion of the section and 20 were dug within the two detention ponds. None of the auger borings encountered cultural material and only a few isolated modern items were found through backhoe trenching.

Six backhoe trenches encountered sparse evidence of historic cultural activity in Section 1. Excavation of Backhoe Trench 15 (BHT 15) revealed a single brick fragment (see Map Sheet 12 in Appendix B). This isolated find does not constitute a site, however, outside the ROW there are surface disturbances and an arrangement of old oaks that suggests a historic homestead was once nearby. BHTs 34-36 produced thin scatters of oyster shell from 0-20 cmbs (Map Sheets 16 and 17). This material has been used as road fill in the past as evidenced by a recently made ditch crossing on the

Table 6-1. Auger borings (AB) and backhoe trenches (BHT) excavated by section

\begin{tabular}{|c|c|c|}
\hline Section & Auger Borings & Backhoe Trenches \\
\hline 1 & 121 & 76 \\
\hline 2 & 63 & 39 \\
\hline 3 & 93 & 61 \\
\hline
\end{tabular}

south side of CR 968Y (between BHTs 36 and 37). At that location, the fill is a mix of oyster shell and sandy clay. BHT 38 (Map Sheet 17), also along CR 968Y, contains unburned and partially burned wood, charcoal, burned clay and concrete fragments. This material is likely from a brush pile burn associated with clearing before or during the construction of CR 968Y. BHT 51 in Detention Pond No. 7 recovered one clear glass bottle less than 50 years old (Figure C-6, Appendix C). BHT 72 uncovered a large lens of partially burned wood, charcoal, ash and burned clay (Figure C-5). The likely source is a recent brush pile or tree stump burn. No cultural material was associated with the charcoal, ash and burned clay lens.

BHT 97 (Map Sheet 4) uncovered a portion of an apparent abandoned landfill. The upper level of the fill included common household debris including tin cans and containers, paper, plastic, and various small metal items. Recovered in this upper level, a scrap of magazine depicting President Richard Nixon greeted by Leonid Brezhnev during a visit to Moscow in 1973 (Figure 6-1) suggests the later deposits occurred in the mid-1970s. The lower levels contained larger automotive and industrial/construction debris, including tires, building tile, steel beams, bundles of rebar, and an intact, empty acetylene tank (Figure 6-2). The depth of the landfill remains indeterminate, as the backhoe failed to encounter undisturbed soil at the practical limits of excavation, at roughly 10 feet below current ground surface.

\section{Section 2}

Sixty-three auger borings and 39 backhoe trenches were excavated in Section 2 (see Table 6-1). Fifty-three of the auger borings were located along the linear portion of the section and ten were dug within the five detention ponds. Thirty-three of the backhoe trenches were located along the linear portion of the section and six were dug within the five detention ponds. None of the auger borings or backhoe trenches encountered cultural material.

Previously recorded site $41 \mathrm{BO} 184$ is contained within the eastern portion of Section 2 (see Figure 1-3); however, it was not part of the current field survey. The results of the testing of site 41BO184 were reported in Mahoney (2003b). 


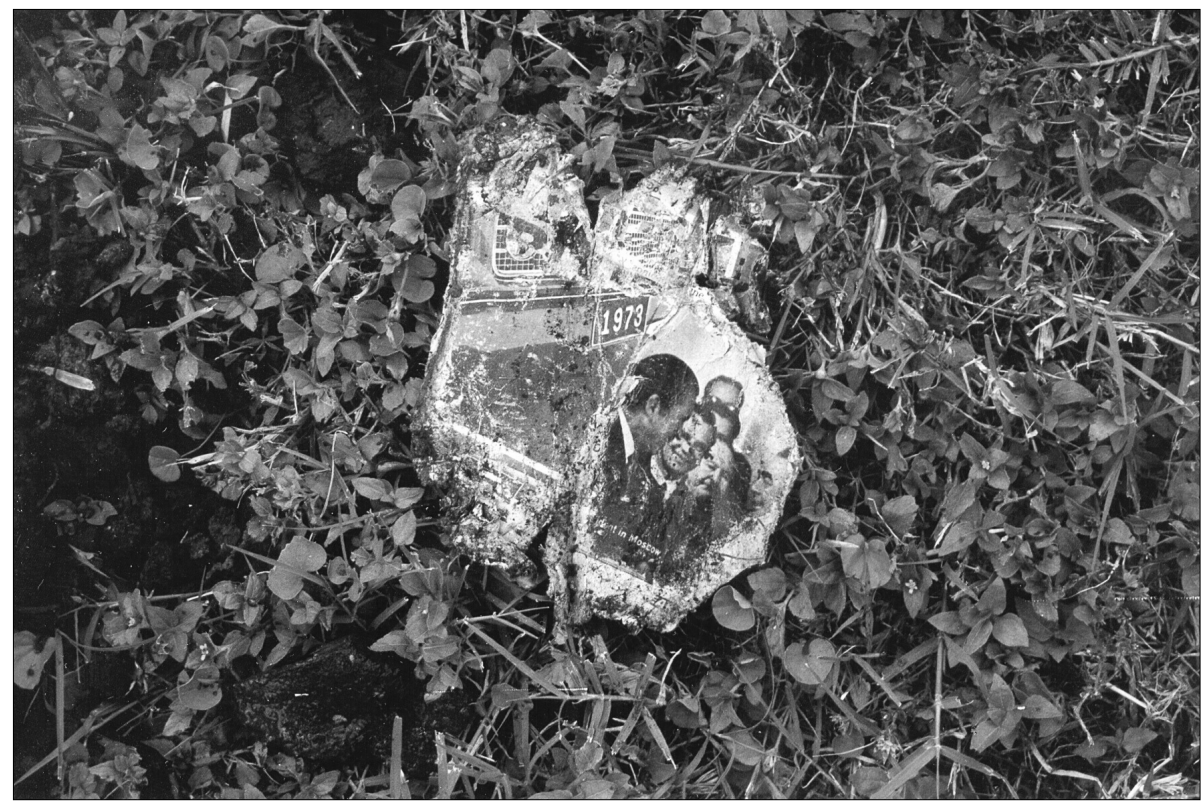

Area of Potential Effect, identified no cultural deposits or features of prehistoric or historic age.

\section{Geoarcheological Investigations}

The backhoe trenches excavated along the SH 35 ROW were located in a relatively homogeneous floodbasin environment. Consequently, many of the trenches shared similar stratigraphic profiles. There were, however, significant differences in stratigraphic environment, surface vegetation, and land use within and between the various sections.

Figure 6-1. Magazine fragment (dating to the early 1970s) encountered in BHT 97.

\section{Section 3}

Ninety-three auger borings and 61 backhoe trenches were excavated in Section 3 (see Table 6-1). Eighty-seven of the auger borings were located along the linear portion of the section and six were dug within the single detention pond. Fifty-eight of the backhoe trenches were located along the linear portion of the section and three were dug within the single detention pond. None of the auger borings or backhoe trenches encountered cultural material.

\section{Antebellum Plantations}

Following the receipt of the HHM (2003) preliminary report on the Brazoria County Historic Context, plantation boundaries were transferred to the TxDOT plan maps of the project area. A 20-m grid was established over each of the subject properties within the APE, resulting in the excavation of 314 auger borings across the combined subject properties (Figure 6-3; Table 6-2). The grid was aligned with the survey transects traversed during the original survey of each plantation, with a single auger boring placed at each node along the grid. In this manner, previously excavated auger borings were relocated and incorporated in the total number of borings for each subject property. Table 6-2 summarizes the number of auger borings excavated within each plantation area. The 314 auger borings, covering $100 \%$ of the portions the three antebellum plantations within the

\section{Section 1}

The 76 backhoe trenches excavated in Section 1 were located almost exclusively in low-relief portions of the Brazos River floodbasin. Despite this apparent geomorphic homogeneity, four slightly different stratigraphic environments were revealed during the course of the investigations. These include (1) poorly drained, heavily forested areas near ponds and swamps; (2) more well drained, grassy pastures and fields, some of which are located near drainage channels; (3) disturbed or heavily modified areas near highways, lawns, and utility facilities; and (4) relatively undisturbed floodplain areas with possible remnant levee deposits.

Three backhoe trenches (BHTs 6, 8, and 10) were placed in poorly drained, heavily wooded, low-lying portions of the Brazos floodplain. Profiles of these three trenches are illustrated in Figures A-1 through A-3, in Appendix A. The stratigraphic sequence in these trenches, while not always the same, is generally comprised of a dark brown to black muddy A horizon (some have Mollic epipedons), underlain by a $\mathrm{Bg}$ or Bkg horizon of gleyed clay. The gleyed $\mathrm{B}$ horizons are considered characteristic of sustained subaqueous environments.

Seven of the profiled trenches (BHTs 12, 15, 16, 19, 23, 40, and 66) were excavated in relatively well-drained pastures and plowed fields, again in more-or-less featureless vertical 


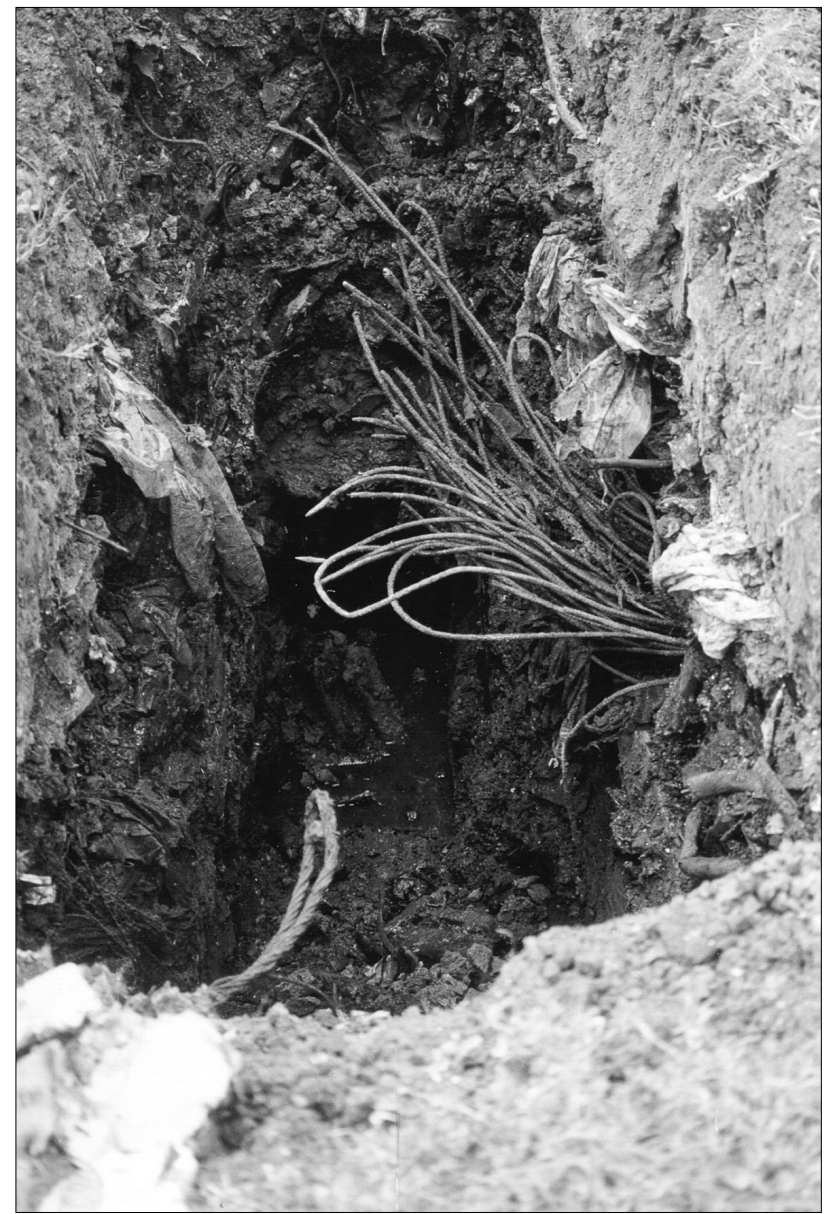

Figure 6-2. Abandoned landfill encountered in BHT 97.

accretion floodplain settings. Two trenches (BHTs 15 and 66), however, were located in floodplain sediments adjacent to ephemeral stream channels. Two representative trench profiles (BHTs 15 and 40) are illustrated in Figures A-4 and A-5. Soils in the seven trenches include A-Bk, and occasionally A-Bt-Bk horizon profiles. While the $\mathrm{A}$ and $\mathrm{Bt}$ horizons are predominately clays and clay loams, the $\mathrm{Bk}$ horizons are generally less fine-grained (sandy clay, sandy clay loam) and are distinctive on the basis of color (generally yellowish brown, yellowish red, reddish brown) and Stage 1-3 pedogenic carbonates. The more sandy texture of the Bk horizons could suggest deposition in non-vertical accretion environments, perhaps as levee or crevasse-splay facies (cf. Baker et al. 1987; Bernard et al. 1970). Finally, in lieu of substantive observable soil carbonates from the other backhoe trenches in Section 1, little can be said concerning the climatic/temporal implications of Stage 1 and Stage 3 carbonates in the reddish Bk horizons just discussed. Both characteristics suggest somewhat older and more varied depositional and pedogenic contexts (i.e., Beaumont Formation?).

Six profiled trenches (BHTs 26, 30, 35, 44, 48, and 57) were located in either nondescript featureless floodplain environs, or in close proximity to landscapes modified by highway construction, landscaping, building construction, and utility service facilities. One representative trench profile (BHT 35) is illustrated in Figure A-6. Coming from rather disparate natural and cultural settings, the stratigraphic sequences evident in these profiles are varied and not especially conducive to the drawing of scientific inference. Three of the trenches (BHTs 26, 30, and 57) exhibited simple A-Bk horizon profiles. All of these soils were comprised of clays and clay loams. One of the A horizons (BHT 57) is noticeably overthickened, while all but one of the Bk horizons have weak Stage 1 carbonates. Backhoe Trench 57 exhibited few, small carbonate nodules. Two of the trenches have Ap horizons, suggesting modern agricultural activity. Two additional trenches have multiple, poorly developed Bt and Btk profiles; however, it is difficult at present to ascribe these slight increases in clay to pedogenic, rather than inherited fluvial or groundwater, processes.

Finally, BHT 72 contained a stratigraphic sequence indicative of multiple fluvial depositional environments. BHT 72 was placed on a low linear rise, visible in a grassy pasture, and also noted on the USGS topographic map of the area. A basin-shaped concentration of burned wood, burned clay, and ash was encountered in the upper Ap/A horizon of this trench profile (Figure A-7). The cultural feature was not associated with artifacts of any kind and its cultural/temporal affiliation is unknown. A modern age, however, is suggested by its Ap-A horizon setting. The location of the trench in a cleared pasture, together with the morphology and content of the feature, suggest that it could represent an episode of tree stump or slash-pile burning. The Ap/A horizon in BHT 72 overlies two Bk soil horizons, the lower of which is comprised of a yellowish red fine sandy loam. Sandy sediments throughout Section 1 were only rarely encountered. In BHT 72, their location within a low linear rise is considered a strong indication that they were once associated with an extensive natural levee that has subsequently suffered attrition from flood activity, channel migration, and historic agriculture.

No cultural resources older than 40 or 50 years were encountered during the backhoe trench investigations in Section 1. There was also no indication of prehistoric cultural activity in the areas investigated. 


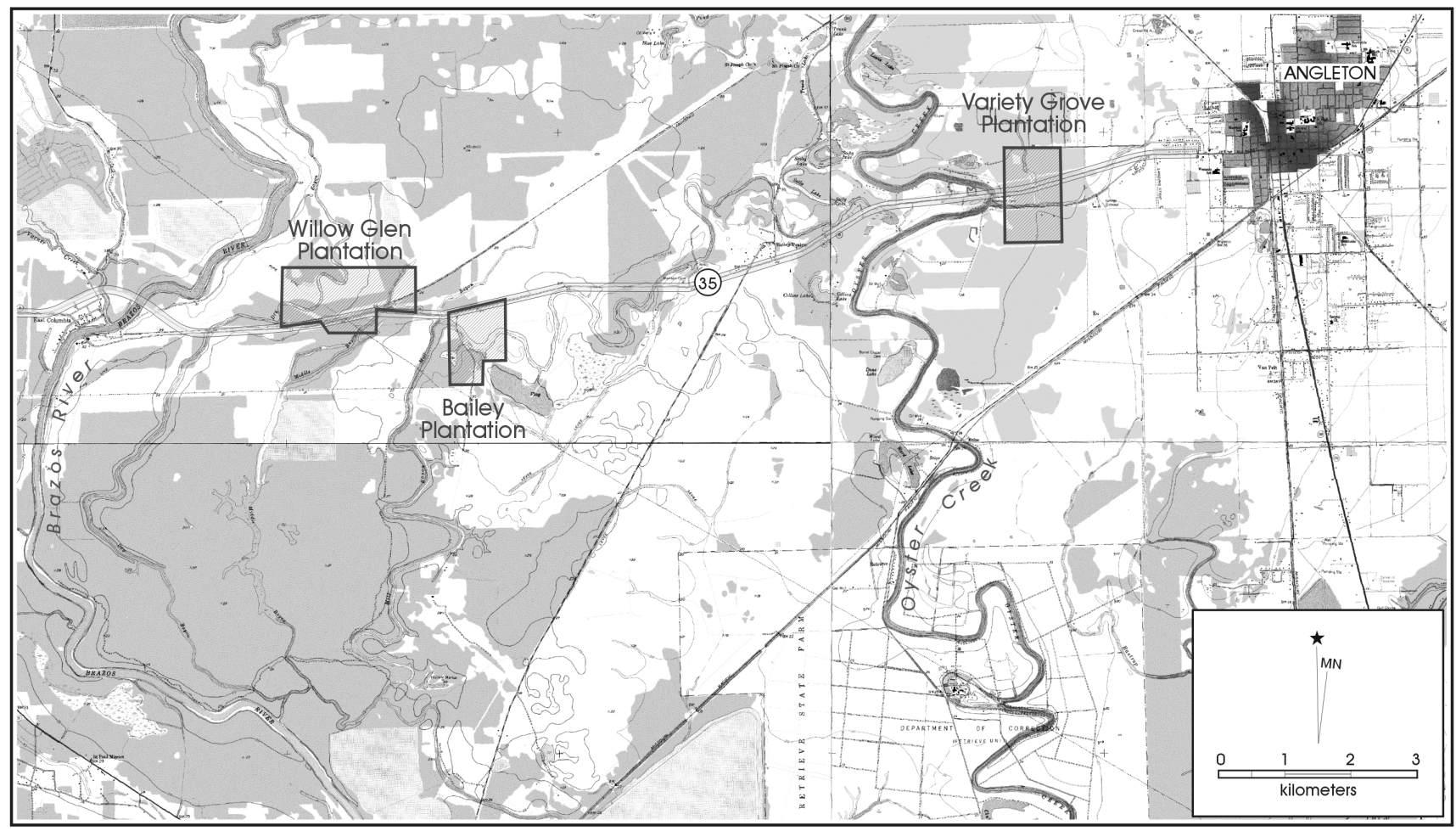

Figure 6-3. Locations of antebellum plantations within the area of potential effect.

\section{Section 2}

Section 2 is also situated within the Brazos River floodbasin and is characterized by channel bottom, channel margin, and overbank/floodbasin depositional environments. Despite a high level of stratigraphic homogeneity, the 39 trenches in Section 2, like those in Section 1, reflect at least two disparate alluvial settings. These are (1) heavily forested, low-lying portions of the floodplain characterized by backswamp or pond sediments; and (2) grassy, more well drained portions of the floodplain characterized by overbank and natural levee deposits.

In Section 2, poorly drained pond or backswamp environments were evident in BHTs 1, 4, 80, 93, and 105. These trench profiles are illustrated in Figures A-8 through

Table 6-2. Auger borings (AB) excavated within plantations

\begin{tabular}{|l|c|}
\hline \multicolumn{1}{|c|}{ Plantation } & Auger Borings \\
\hline Variety Grove & 88 \\
\hline Bailey & 101 \\
\hline Willow Glen & 125 \\
\hline
\end{tabular}

A-12. Two of the trenches (BHTs 1 and 4) revealed clay soils with relatively simple $\mathrm{A}-\mathrm{Bg}$ profiles (Figures $\mathrm{A}-8$ and A-9), while a third (BHT 80; Figure A-10) was comprised of an Ap-A-Bkg profile. The gleyed Bg horizons, like those encountered in all five poorly drained trench settings, reflect sustained subaqueous environmental conditions. A fourth backhoe trench, BHT 93, was comprised of clay and silty clay sediments in an Ap-A-Btg-Bk1-Bk2 profile (Figure A-11). The final trench, BHT 105, was also located in a low-lying, heavily forested area, but exhibited $\mathrm{A}, \mathrm{Bg}$, and $\mathrm{Bkg}$ horizons arranged in a complex lateral facies relationship (Figure A-12). The BHT 105 profile appears to reflect the lateral contact between former pond and pond margin facies, which may or may not have experienced measurable expansion/contraction or lateral migration subsequent to inundation.

Three trenches in Segment 2 were excavated in grassy, relatively well-drained pasture settings. Each of these trenches (BHTs 86, 91, and 96) contained muddy A, Ap, $\mathrm{Bt}, \mathrm{Bk}$, or $\mathrm{Bg}$ horizons interpreted as probable overbank or overbank/pond deposits. These were underlain by sandy Bk, $2 \mathrm{Bk}$, or $\mathrm{C}$ horizon sediments interpreted as probable natural levee deposits (Figures A-13 through A-15). 
In addition to the low-lying gleyed trenches, and those situated in well-drained sandy deposits, three of the Segment 2 trenches were located in close proximity to Oyster Creek, the sole perennial stream extant in the Section 2 ROW. These trenches (BHTs 98, 99, and 101) exposed generally thick, disturbed surface soils containing recent trash and oyster shell road aggregate. The Ap horizons were underlain by medium to thick beds of red and gray clays (BHT 98) and alternating thin to medium beds of massive clay and massive to planar laminated loamy fine sand (BHTs 99 and 101). In BHT 98, which was placed along the riser and tread of the lowest terrace/floodplain (i.e., $\mathrm{T}_{1}$ ), the red and gray clay units could represent the top portion of a fining upward fluvial (meandering stream) sequence. In BHTs 99 and 101, which were placed on the tread of the highest visible terrace $\left(\mathrm{T}_{2}\right.$ ?) west of Oyster Creek, the alternating clay and loamy sand units extant beneath the disturbed surface soil, do not follow a normal fining upward pattern, and are therefore difficult to interpret genetically. They could reflect upper point bar or disturbed natural levee facies; however, due to their close proximity to $\mathrm{SH} 35$, deposition and/or modification by previous road construction cannot easily be dismissed as a possible agent in their formation and postdepositional history. The stratigraphic profile from BHT 101 is illustrated in Figure A-16.

During the course of the backhoe trench investigations in Section 2, no cultural resources older than 40 or 50 years were encountered. There was also no indication of prehistoric cultural activity in the areas investigated.

\section{Section 3}

Sixty-one trenches were excavated along the SH 35 ROW in Section 3. The section is composed of Sections 3a and 3b. In Section 3a (east of West Columbia), SH 35 traverses a portion of the Brazos River floodbasin, and includes the Brazos River and Varner Creek crossings. In Section $3 b$ (southwest of West Columbia), SH 35 traverses a portion of the ancestral Colorado River valley, and includes the San Bernard River crossing. The results from each of the stream crossing trenches follow the discussion of results from the linear portion of the ROW.

Located west of the Brazos River, the trenches in Section 3 can be organized into four somewhat indistinct topographic and modern environmental settings. These are (1) grassy and partially forested pasture lands; (2) cleared areas associated with modern yards/housing developments, utility corridors, and abandoned lots; (3) heavily forested portions of the Brazos and San Bernard river floodplains; and (4) low-relief Beaumont Formation(?) uplands west of the San Bernard floodplain. Despite these varied environments, soils and sediments exposed in Section 3 were generally homogeneous and dominated by fine-grained overbank and ponded/ backswamp floodplain deposits. Being very similar to those in previously investigated Sections 1 and 2, only two of the trenches in Section 3 away from the banks of the streams were formally profiled. These are BHTs 149 and 175.

Eleven trenches in Section 3 were located in grassy pasture land settings. Unlike pasture areas in Sections 1 and 2, which included a significant number of sandy levee deposits, the sediments in Section 3 were generally more fined-grained and similar to those placed in the forested floodplain areas (i.e., comprised of A horizon muds over gleyed $\mathrm{Bg} / \mathrm{Bkg}$ and reddish sandy clay $\mathrm{Bk}$ horizons). The three trenches excavated in Detention Pond No. 9 are included in this pasture land setting. No trenches in this setting were profiled.

Four of the trenches in Section 3 were excavated in settings modified by modern utility corridors and housing developments. These trenches (BHTs 134, 135, 136, and 141) contained highly disturbed surface soils but were underlain by extant, gleyed pond sediments. No trenches in this setting were profiled.

Ten trenches in Sections 3a and 3b were excavated in heavily treed portions of the Brazos and San Bernard river floodplains. These trench profiles were comprised of dark gray to black clay A horizons underlain by gleyed muds and reddish sandy clays. These sediments are apparently associated with overbank and backswamp/pond depositional environments. No trenches in this setting were profiled.

BHT 149 was located in low-relief uplands west of the San Bernard River. A total of 24 trenches was placed in this portion of the SH 35 project area and all revealed stratigraphic profiles comprised of dark gray to black A horizon clays, strongly gleyed Bg or Bkg horizons (muds), and basal units of reddish 2Bk or 3Bk loamy sands and sandy clays characterized by Stage 4 carbonate nodules (Figure A-17). Potential groundwater sources of carbonate not withstanding, the lower $\mathrm{CaCO}_{3}$-rich sandy deposits appear significantly older than the overbank or natural levee sediments encountered in the San Bernard or Brazos river floodplains. Although substantive temporal information was not obtained during the investigations, the high degree of 
pedogenic(?) carbonates present in the lower units could suggest a Pleistocene or older age for these deposits (i.e., Beaumont Formation?).

BHT 175 was located west of the San Bernard River in Section $3 \mathrm{~b}$. The upper $1.65 \mathrm{~m}$ of BHT 175 were comprised of clay and silty clay A-Bg soil horizons that lacked visible carbonates (Figure A-18). In the western portion of the trench, the Bg horizon was underlain by a reddish 2Btk soil with large carbonate nodules, and a reddish unit of loamy fine sand. The backhoe trenches excavated immediately east of BHT 175 (BHTs 146-148) were comprised of San Bernard River floodplain sediments, while those excavated west of the trench (BHTs 149-174) were comprised of upland (Beaumont?) sediments characterized by basal units with significant pedogenic carbonates. This suggests that BHT 175 was located at, or very near, the modern floodplainBeaumont/upland margin.

\section{Brazos River Crossing}

Four backhoe trenches were excavated on the banks of the Brazos River. Two of the trenches were placed on the rightdescending bankline of the river (BHTs 115 and 116), and two were placed on the left-descending bankline (BHTs 117 and 118).

The profiles of BHTs 115 and 116 are illustrated in Figures A-19 and A-20. Both contained Ap surface horizons comprised of clay loam, oyster shell aggregate, and recent debris. The surface soils were underlain by a number of generally structureless units of mud and sand that appear to be modern road fill. These disturbed deposits were extant to depths ranging from $1.25-1.75 \mathrm{~m}$ below surface and were underlain by Brazos River overbank clays (see Figures A-19 and A-20).

BHTs 117 and 118 also contained disturbed surface soils, but the underlying units were more coarse-gained and somewhat problematic in terms of depositional origin (Figures A-21 and A-22). In BHT 117, along the south side of the SH 35 bridge, the Ap surface horizon is underlain by a thin Bk horizon of fine sandy loam, and four thin to medium-thick, alternating beds of sandy loam and clay loam. The latter are inclined and morphologically suggestive of shallow channel fill deposits (Figure A-21). As per depositional environment, the sequence of alternating medium fine sands and thin muds is suggestive of upper point bar facies (cf. Reineck and Singh 1980; Walker and Cant 1984), although their proximity to SH 35 and the existing bridge cannot rule out the possibility of significant disturbance from modern construction activity.

In BHT 118, along the north side of the SH 35 bridge, sediments below the Ap soil consisted of four medium to thick beds of massive, planar laminated, planar crosslaminated, and convolute laminated fine sands (cf. Boggs 1987). Like the interbedded sediments exposed in BHT 117, the Unit II and III sands in BHT 118 are markedly inclined in a westerly, or riverward, direction (Figure A-22). Again, this morphology could indicate some type of channel or ridge and swale fill. The trench itself, however, was located on a westward-sloping portion of the contoured SH 35 right-ofway and it is possible that Units II-IV could be modern road fill materials. On the other hand, the lithology and laminated structure of the BHT 118 deposits are not atypical of some point bar sequences (Boggs 1987:163; Walker and Cant 1984). For these reasons, the depositional origin of the BHT 118 deposits remains problematic.

No cultural materials were observed in the four Brazos River trenches. This is not particularly surprising given the generally high levels of modern disturbance evident and the possibility that significant portions of the exposed sediments may be modern road-fill material. It is also probable that any or all of the potentially intact alluvial deposits examined are geologically very recent (i.e., late Holocene or Historic in age) given their location in the upper 1.5-2.0 $\mathrm{m}$ of the Brazos River floodplain (cf. Abbott 2001:116-122). To complement the generally shallow nature of the backhoe trench investigations, the cutbanks exposed along the west side of the Brazos River, below and a short distance north of BHT 115, were briefly examined. These cutbanks revealed a number of buried soils. These include a prominent, truncated A horizon soil extant at $5.5 \mathrm{~m}$ below the modern floodplain surface, two probable Bt or Btk horizon soils extant at about 5.25 and $6.25 \mathrm{~m}$ below surface, and two possible buried A horizons visible at depths ranging from about 3.0 to $1.0 \mathrm{~m}$ below surface. At least one of the A horizon paleosols could be temporally analogous to the Asa soil identified along the Brazos River near Bryan/College Station, Texas by Waters and Nordt (1995). The Asa soil exposed in that portion of the Brazos valley has yielded radiocarbon ages ranging from 880 to 1320 years BP (Waters and Nordt 1995). The dark soil visible at roughly $5.5 \mathrm{~m}$ below the surface is also the most well-exposed of those identified but is significantly lower stratigraphically than the Asa soil identified by Waters and Nordt. This soil could therefore prove to be older than about 1500 years BP. 
Cumulatively, however, all of the soils exposed below BHT 115 suggest that alluvial sediments less than about 1-3 m below the surface in this immediate area could be quite recent in age (i.e., late Holocene). It should be noted, however, that at present, any substantive correlation between the soils exposed near SH 35 and other previously documented paleosols along the Brazos River would be highly tentative at best. Nevertheless, matrix samples for humate dates were collected from the three probable or potential A horizon soils near BHT 115, and their eventual analysis could prove a very valuable adjunct to the current investigations. As Abbott (2001) and others have demonstrated, any resultant radiocarbon ages dating from about 3500 to 5500 years BP could be significantly influenced by the incorporation of older organic material. Such potential bias, however, could still prove useful in establishing a temporal framework for local landscape and soil conditions (Abbott 2001:118-119).

\section{Varner Creek Crossing}

Located in Section 3a, four backhoe trenches were excavated at Varner Creek, again on both banks of the creek and both north and south of the existing bridge. These trenches, BHTs 119-122, were generally similar and revealed disturbed surface soils overlying muddy overbank sediments. In BHT 122 , however, the extant floodplain deposits exhibited more significant levels of pedogenic soil development. As illustrated in Figure A-23, the BHT 122 profile consisted of an Ap surface horizon and two underlying units that appear to be modern road fill. These were underlain at $.50-.60 \mathrm{~m}$ below surface by Btk-2Bk-2Btk clay and fine sandy clay overbank deposits. The $2 \mathrm{Btk}$ horizon contained very few, small carbonate nodules, while the other two horizons reacted strongly to $10 \% \mathrm{HCl}$ but did not contain visible carbonate forms. No cultural materials were observed in the four trenches excavated along Varner Creek.

\section{San Bernard River Crossing}

The San Bernard River crossing in Section 3b was investigated by four backhoe trenches placed along the east and west banks of the river. The two trenches located on the west bank of the river (BHTs 142 and 143) exhibited highly disturbed clay and clay loam sediments in the upper $.65-.75 \mathrm{~m}$ portions of the profile and apparently undisturbed alluvial sediments below about $.75 \mathrm{~m}$. BHT 142 was located beside a boat ramp south of the SH 35 bridge and immediately adjacent to the channel. Here, the apparently undisturbed alluvium consisted of upward-fining loamy sands and clays, possibly associated with a formerly extant point bar. BHT 143 was located about $5 \mathrm{~m}$ above the modern channel on a contoured surface north of the bridge.
Undisturbed alluvial sediments in BHT 143 were comprised of alternating beds of mud and fine sand. These could have been deposited in the upper portion of the same point bar evident in BHT 142.

The two trenches excavated along the north side of the $\mathrm{SH}$ 35 bridge, BHTs 144 and 145, were comprised of thin disturbed A horizons which were underlain by massive, planar and convolute laminated fine sands. These sediments are more than likely natural levee deposits. Like all of the trenches in Section 3, no cultural materials older than 40 or 50 years were observed in the four backhoe trenches excavated along the San Bernard River. 


\title{
Chapter 7: Summary
}

\author{
Richard B. Mahoney and David D. Kuehn
}

This brief chapter summarizes the results of the archeological and geoarcheological field efforts and the subsequent recommendations.

\section{Archeology}

This document reports on the results of intensive archeological survey and geomorphic investigations of an approximately 15-mile-long right-of-way along SH 35 between Angleton and Old Ocean in Brazoria County. The entirety of the approximate 15-mile linear Area of Potential Effect was subject to intensive archeological and geoarcheological survey, including a $100 \%$ pedestrian survey, mechanical auger boring, and backhoe trenching. The project area is comprised of three sections, including eight detention ponds. Section 1 was investigated with 121 auger borings and 76 backhoe trenches; Section 2 with 63 auger borings and 39 backhoe trenches; and Section 3 with 93 auger borings and 61 backhoe trenches. Three antebellum plantations identified by $\operatorname{HHM}$ (2003) within the APE were more intensively investigated with the following number of auger borings: Variety Grove $(\mathrm{n}=88)$, Bailey $(\mathrm{n}=101)$, and Willow Glen $(\mathrm{n}=125)$.

Succinctly, 591 auger borings and 176 backhoe trenches were excavated along the length of the project area encountering no evidence of significant cultural deposits. It is, therefore, the conclusion of this archeological survey that, with the single exception of site 41BO184, the current and proposed ROW contains no significant archeological materials, and the planned corridor improvements for State Highway 35 are recommended to proceed without further cultural resources investigations. Testing of the National Register of Historic Places and State Archeological Landmark eligibility of 41BO184 will be forthcoming.

\section{Geoarcheology}

The excavation and interpretation of 76 backhoe trenches in Section 1 revealed a remarkably broad and homogeneous stratigraphic record of late Quaternary floodplain construction. With a few exceptions, all of the sediments encountered in the backhoe trenches can be assigned to Holocene overbank flooding of the Brazos River and its downreach tributaries. Additional meandering stream facies were only rarely identified, and include possible levee, channel, and backswamp/pond deposits.

Soils and stratigraphy in the 39 trenches excavated in Section 2 suggest deposition within backswamp/pond and overbank floodplain environments. A third depositional setting was evident in three trenches placed immediately adjacent to Oyster Creek. One of these trenches exposed muddy sediments indicative of vertical accretion within a meandering stream environment, while two were comprised of alternating thin to medium beds of massive clay and massive to planar laminated loamy sand. The latter are difficult to classify environmentally, but could represent upper point bar or modified natural levee deposits. Surface units in all three trenches appeared heavily disturbed by previous road construction activity.

Sixty-one backhoe trenches were excavated in Section 3, which included the Brazos River, San Bernard River, and Varner Creek crossings. Sediments exposed in the four trenches excavated at the Brazos River crossing were highly disturbed, but included possibly intact deposits associated with overbank and point bar depositional environments. The age of these sediments has not been determined, but paleosols observed in cutbanks exposed near BHT 115 could suggest deposition during the late Holocene.

The four trenches excavated at the Varner Creek crossing revealed significant levels of modern road construction disturbance. The disturbed sediments in these trenches were underlain by apparently intact overbank deposits, also of probable late Holocene age.

Backhoe trenches away from the major streams in Section 3 were located in a variety of modern environmental settings. Stratigraphic sequences in the eastern and central portions of the section were dominated by Holocene Brazos River and San Bernard River floodplain sediments, while sequences in the western portion of the section were associated with potentially older, pre-Holocene (i.e., Beaumont Formation) depositional environments.

No prehistoric cultural materials or historic materials more than 40-50 years old were encountered during the course of the auger boring and backhoe trench investigations. This lack of artifacts could be at least partially due to the relatively 
young age of most of the sediments investigated. Indeed, the review of previously recorded prehistoric sites throughout the county has demonstrated intact cultural deposits restricted primarily to the Late Prehistoric period and in association with landforms dominated by sandy, alluvial deposits. The widespread occurrence of gleyed pond deposits within the Area of Potential Effect could suggest that much of the project area was poorly drained and/or dominated by backswamps during the aggradation of the surface and near-surface portions of the floodbasin. Prior to the construction of modern flood-control devices, large portions of the right-of-way may have been ill-suited to significant cultural occupation. Regardless of age or former drainage conditions, the trenching does suggest that significant cultural resources are not likely to be impacted by road construction activities that may occur in the upper circa $1.5 \mathrm{~m}$ of the right-of-way. For this reason, no additional archeological or geoarcheological investigations are recommended for the areas investigated. 


\section{References Cited}

Abbott, J. T.

2001 Houston Area Geoarcheology: A Framework for Archeological Investigation, Interpretation, and Cultural Resource Management in the Houston Highway District. Archeological Studies Program, Report 27. Texas Department of Transportation, Environmental Affairs Division, Austin.

Angel, C.

2002 Depositional Environments and Geotechnical Properties of the Beaumont Formation, Brazoria County, Texas. South Central Arc Users Group, 12 ${ }^{\text {th }}$ Annual Meeting, Texas, February 2002.

Angleton Times

1985 "Old Cemetery Link to Past." 11 July.

Aten, L. E.

1971 Excavations at the Dow-Cleaver Site, Brazoria County, Texas. Technical Bulletin No. 1. Texas Archeological Salvage Project.

1979 Indians of the Upper Texas Coast. Ph.D. dissertation, The University of Texas at Austin.

Baker, V., R. Kochel, and P. Patton (editors)

1987 Flood Geomorphology. John Wiley \& Sons, New York.

Barnes, V. E.

1968 Geologic Atlas of Texas, Houston Sheet. Bureau of Economic Geology, University of Texas at Austin.

Bernard, H., C. Major, Jr., B. Parrott, and J. LeBlanc, Sr.

1970 Recent Sediments of Southeast Texas: A Field Guide to the Brazos Alluvial and Deltaic Plains and the Galveston Barrier Island Complex. Texas Bureau of Economic Geology Guidebook 11, The University of Texas at Austin.

Blum, M. D.

1992 Modern Depositional Environments and Recent Alluvial History of the Lower Colorado River, Gulf Coastal Plain of Texas. Ph.D. Dissertation, The University of Texas at Austin.

Blum, M. D., R. A. Morton, and J. M. Durbin

1995 "Deweyville" Terraces and Deposits of the Texas Gulf Coastal Plain. Transactions of the Gulf Coast Association of Geological Societies 45:53-60.

Boggs, S., Jr.

1987 Principles of Sedimentology and Stratigraphy. Merrill Publishing, Columbus, Ohio.

Bomar, G. W.

1995 Texas Weather. The University of Texas Press, Austin.

Brandt, E. N.

1997 Growth Company, Dow Chemical's First Century. Michigan State University Press, East Lansing. 
Bureau of Economic Geology

1992 Geologic Map of Texas. Bureau of Economic Geology, The University of Texas at Austin.

1996 Physiographic Map of Texas. Bureau of Economic Geology, The University of Texas at Austin.

Campbell, R. B.

1989 An Empire for Slavery - The Peculiar Institution in Texas, 1821-1865. Louisiana State University Press, Baton Rouge.

Carlson, S. B. (editor)

1995 The Anson Jones Plantation: Archaeological and Historical Investigations at 41WT5 and 41WT6, Washington County, Texas. Reports of Investigations, No. 2. Center for Environmental Archaeology, Texas A\&M University, College Station.

Castille, G. J., and J. P. Whelan

1986 Cultural Resources Survey and Assessment of the Proposed Department of Energy Freeport to Texas City Pipeline, Brazoria and Galveston Counties, Texas. Coastal Environments, Inc., Baton Rouge.

Champomier, P. A.

1852/53 Statement of the Sugar Crop made in Louisiana in 1852-53. New Orleans.

Creighton, J.

1986 A Narrative History of Brazoria County. Brazoria County Historical Commission.

Crenwelge, G. W., J. D. Crout, E. L. Griffen, M. L. Golden, and J. K. Baker

1978 Soil Survey of Brazoria County, Texas. United States Department of Agriculture, Soil Conservation Service.

Curlee, A.

1932 A Study of Texas Slave Plantations, 1822 to 1865. Ph.D. dissertation, The University of Texas at Austin.

Dering, J. P., and D. Ayers

1977 Archeological Investigations in the Village of Oyster Creek, Brazoria County, Texas. Report No. 42. Anthropology Research Laboratory, Texas A\&M University, College Station.

Dismukes, D. C.

2003 Archeological Testing of 41BO185, A Possible Civil War Era Military Camp, West Columbia, Brazoria County, Texas. Occasional Papers of the Archeological Studies Program, Volume 2, Number 2, July 2003. Environmental Affairs Division, Texas Department of Transportation, Austin.

Dorsett, J.

1981 Blacks in Reconstruction Texas, 1865-1877. Ph.D. dissertation, AddRan College of Arts and Sciences.

Dupre, W.

2002 Depositional and Geotechnical Properties of the Beaumont Formation, Brazoria County, Texas. Management and Monitoring Series, The Environmental Institute of Houston.

Earls, A. C., and M. S. F. Tomka

1994 Historic and Prehistoric Archeological Excavations at Varner-Hogg Plantation State Historical Park, Brazoria County, Texas. Texas Parks and Wildlife Department, Public Lands Division, Cultural Resources Program, Austin. 
Espey, Huston \& Associates

1996 Archaeological Data Recovery on the Jones Lake Site (41BO79), Brazoria County, Texas. Document No. 950876. Espey, Huston \& Associates, Inc., Austin.

Few, J.

1994 Sugar and Cotton Production in the Texas Sugar Bowl. In Antebellum Texas, Brazos Style, 1994 Session. Brazoria County Historical Museum, February 26, 1994.

1999 Texas' Early Sugar Industry: A Comparative Study of Four Antebellum Sugar Mills in Brazoria County, Texas. Bulletin of the Texas Archeological Society 70:533-540.

Hamilton, D. L.

1988 Archeological Investigations at Shy Pond, Brazoria County, Texas. Bulletin of the Texas Archeological Society 58:77-145.

Harris, R.

2003 "David Graham Mills.” The Handbook of Texas Online. <http://www.tsha.utexas.edu/handbook/online/articles/ view/MM/fmi64.html> Accessed September 2003.

Hester, T. R.

1980 A Survey of Paleo-Indian Archaeological Remains along the Texas Coast. In Papers on the Archaeology of the Texas Coast, edited by L. Highley and T. R. Hester, pp. 1-12. Special Report No. 11. Center for Archaeological Research, The University of Texas at San Antonio.

HHM

2003 Archival Research, Interim Findings Report, SH 35, Brazoria County. HHM, Inc., Houston. Manuscript on file Center for Archaeological Research, The University of Texas at San Antonio.

Hilliard, S.

1979 Site Characteristics and Spatial Stability of the Louisiana Sugarcane Industry. Agricultural History 76.

Hole, F., and R. G. Wilkinson

1975 Shell Point: A Coastal Camp and Burial Site in Brazoria County. Bulletin of the Texas Archeological Society 44:5-50.

Iruegas, S. A.

2003 Plantation Settlement Patterns: Landscapes in Plantation Archeology. Manuscript on file Texas Historical Commission, Austin.

Johnson, W.

1961 A Short History of the Sugar Industry in Texas. Texas Gulf Coast Historical Association Publications.

Kleiner, D. J.

2003a "Brazoria County.” The Handbook of Texas Online. <http://www.tsha.utexas.edu/handbook/online/articles/view/ BB/hcb12.html> Accessed September 2003.

2003b “Magnesium Industry.” The Handbook of Texas Online. <http://www.tsha.utexas.edu/handbook/online/articles/ view/MM/dkm1.html> Accessed September 2003. 
Lowe, R. G., and R. B. Campbell

1987 Planters and Plain Folk, Agriculture in Antebellum Texas. Southern Methodist University, Dallas.

Mahoney, R. B.

2003a 41BO184 Site Assessment, Section 2 of the State Highway 35 between Angleton and West Columbia Corridor Improvement Project, Brazoria County, Texas. Manuscript on file Center for Archaeological Research, The University of Texas at San Antonio.

2003b National Register Eligibility Testing of Site 41BO184 Brazoria County, Texas. Center for Archaeological Research, The University of Texas at San Antonio. Interim Report.

McCormick, A. P.

1897 Scotch-Irish in Ireland and in America. New Orleans.

McDavid, C.

1997 Descendants, Decision, and Power: The Public Interpretation of the Archaeology of the Levi Jordan Plantation. Historical Archaeology 31-3:114-131.

McGowan, J. H., L. F. Brown, Jr., T. J. Evans, W. L. Fisher, and C. G. Groat

1976 Environmental Geologic Atlas of the Texas Coastal Zone-Galveston-Houston Area. Bureau of Economic Geology, The University of Texas at Austin.

Murray, M.

1940 Home Life on Early Ranches of Southwest Texas. The Cattleman (November 1940).

Platter, A. A.

1961 Educational, Social, and Economic Characteristics of the Plantation Culture of Brazoria County, Texas. Unpublished Ph.D. Dissertation. College of Education, University of Houston.

Powers, B. J.

1994 From Cotton Fields to Oil Fields: Economic Development in a New South Community, 1860-1920. Ph.D. dissertation, University of Houston.

Reineck, H. E., and I. B. Singh

1980 Depositional Sedimentary Environments, $2^{\text {nd }}$ edition. Springer-Verlag, Berlin.

Ricklis, R. A.

1995 Prehistoric Occupation of the Central and Lower Texas Coast. Bulletin of the Texas Archeological Society 66: 265-300.

Roell, C. H.

2003 "Charles D. Sayre.” The Handbook of Texas Online. $<$ http://www.tsha.utexas.edu/handbook/online/articles/view/ SS/fsa43.html> Accessed September 2003.

Smallwood, J. M.

1981 Time of Hope, Time of Despair-Black Texans During Reconstruction. Kennikat Press, Port Washington, New York. 
Strobel, A. J.

1930 The Old Plantations and their Owners of Brazoria County, Texas. The Union National Bank, Houston, Texas.

Texas Department of Agriculture

1909 Year Book 1909. Texas Department of Agriculture Bulletin. Von Boeckmann-Jones Company, Austin.

Texas Historical Commission (THC)

2003a Archeological Sites Atlas, Texas Historical Commission. Accessed August 2003.

2003b Historic Sites Atlas, Texas Historical Commission. Accessed August 2003.

Tuffly, E. L., T. G. Jordan, and J. R. Buchanan.

1976 Cultural and historical maps of Texas from the Atlas of Texas. Bureau of Business Research, University of Texas at Austin.

Turner, S.

1982 Exploring the Landscape Design of Antebellum Plantations. Texana II: Cultural Heritage of the Plantation South. Texas Historical Commission, Austin.

Vlach, M.

1993 Back of the Big House - The Architecture of Plantation Slavery. University of North Carolina Press, Chapel Hill.

Walker, H. J., and J. M. Coleman

1987 Atlantic and Gulf Coastal Province. In Geomorphic Systems of North America, edited by W. L. Graf, pp. 51-110. Geological Society of America, Centennial Special Volume 2, Boulder, Colorado.

Walker, R. G., and D. J. Cant

1984 Sandy Fluvial Systems. In Facies Models, edited by R. G. Walker, pp. 71-89. Geoscience Canada Reprint Series 1.

Waters, M. R., and L. C. Nordt

1995 Late Quaternary Floodplain History of the Brazos River in East-Central Texas. Quaternary Research 43:311-319.

Weir, M.

2003 "James Briton Bailey." The Handbook of Texas Online. <http://www.tsha.utexas.edu/handbook/online/articles/ view/BB/fba8.html> Accessed September 2003.

White, R. E.

1957 Cotton Ginning in Texas to 1861. Southwestern Historical Quarterly vol. 61.

Whitsett, $\mathrm{H}$.

1977 Letter Report to the Texas Historical Commission. Texas Water Quality Development Board, Austin.

Williamson, T. A.

1987 The Munsons of Texas: An American Saga. Privately published, T. A. Williamson, Dallas, Texas.

Wooster, R. F.

1961 Notes on Texas' Largest Slaveholders, 1860. Southwestern Historical Quarterly 65:72. 


\section{Additional References Consulted for Historic Context Chapter}

Brown, K. L.

1994 Material Culture and Community Structure: The Slave and Tenant Community at Levi Jordan's Plantation, 18481892. In Working Toward Freedom: Slave Society and Domestic Economy in the American South. University of Rochester Press, Rochester, New York.

Campbell, R. B., and R. G. Lowe.

1977 Wealth and Power in Antebellum Texas. Texas A\&M University, College Station.

1979 Some Economic Aspects of Antebellum Texas Agriculture. Southwestern Historical Quarterly 82.

Debow's Review, Agricultural, Commercial, Industrial Progress and Resources

1948 “Sugar Manufacture." Issues 4-5, October-November.

Holbrook, A. C.

1973 A Glimpse of Life on Antebellum Slave Plantations in Texas. Southwestern Historical Quarterly 76.

Roark, J. L.

1977 Masters Without Slaves: Southern Planters in the Civil War and Reconstruction. W.W. Norton \& Company, New York.

Wooster, R.

1967 Wealthy Texans, 1860. Southwestern Historical Quarterly 71. 